\title{
Impact of lake-level changes on the formation of thermogene travertine in continental rifts: Evidence from Lake Bogoria, Kenya Rift Valley
}

\author{
ROBIN W. RENAUT*, R. BERNHART OWEN†, BRIAN JONES + , JEAN-JACQUES \\ TIERCELIN§, CORINNE TARITS $\uparrow$, JOHN K. EGO** and KURT O. KONHAUSER \\ *Department of Geological Sciences, University of Saskatchewan, Saskatoon, SK, Canada S7N 5E2 \\ (E-mail: robin.renaut@usask.ca) \\ $\dagger$ Department of Geography, Hong Kong Baptist University, Kowloon Tong, Hong Kong \\ $\$$ Department of Earth and Atmospheric Sciences, University of Alberta, Edmonton, AB, Canada T6G 2E3 \\ $\S U M R 6118$ Géosciences Rennes, Equipe Dynamique des bassins, Université de Rennes 1, Campus de \\ Beaulieu, Bâtiment 15, 35042 Rennes cedex, France \\ -UMR CNRS 6538 'Domaines Océaniques', Université de Bretagne Occidentale, Institut Universitaire \\ Européen de la Mer, Place Nicolas Copernic, 29280 Plouzané, France \\ **National Oil Corporation of Kenya, AON Minet House, Off Nyerere Road, Nairobi, Kenya
}

\begin{abstract}
Travertine is present at $20 \%$ of the $c a 60$ hot springs that discharge on Loburu delta plain on the western margin of saline, alkaline Lake Bogoria in the Kenya Rift. Much of the travertine, which forms mounds, low terraces and pool-rim dams, is sub-fossil (relict) and undergoing erosion, but calcite-encrusted artefacts show that carbonate is actively precipitating at several springs. Most of the springs discharge alkaline ( $\mathrm{pH}: 8 \cdot 3$ to $8 \cdot 9$ ), $\mathrm{Na}-\mathrm{HCO}_{3}$ waters containing little $\mathrm{Ca}\left(<2 \mathrm{mg} \mathrm{l}^{-1}\right)$ at temperatures of 94 to $97 \cdot 5^{\circ} \mathrm{C}$. These travertines are unusual because most probably precipitated at temperatures of $>80^{\circ} \mathrm{C}$. The travertines are composed mainly of dendritic and platy calcite, with minor Mg-silicates, aragonite, fluorite and opaline silica. Calcite precipitation is attributed mainly to rapid $\mathrm{CO}_{2}$ degassing, which led to high-disequilibrium crystal morphologies. Stratigraphic evidence shows that the travertine formed during several stages separated by intervals of non-deposition. Radiometric ages imply that the main phase of travertine formation occurred during the late Pleistocene ( $c a 32$ to $35 \mathrm{ka}$ ). Periods of precipitation were influenced strongly by fluctuations in lake level, mostly under climate control, and by related changes in the depth of boiling. During relatively arid phases, meteoric recharge of ground water declines, the lake is low and becomes hypersaline, and the reduced hydrostatic pressure lowers the level of boiling in the plumbing system of the hot springs. Any carbonate precipitation then occurs below the land surface. During humid phases, the dilute meteoric recharge increases, enhancing geothermal circulation, but the rising lake waters, which become relatively dilute, flood most spring vents. Much of the aqueous $\mathrm{Ca}^{2+}$ then precipitates as lacustrine stromatolites on shallow firm substrates, including submerged older travertines. Optimal conditions for subaerial travertine precipitation at Loburu occur when the lake is at intermediate levels, and may be favoured during transitions from humid to drier conditions.
\end{abstract}

Keywords Geothermal, hot spring, Kenya Rift, saline lake, travertine. 


\section{INTRODUCTION}

Geothermal activity and associated hot-spring deposits are common features of continental rifts. Extensional faulting enables deep fluid circulation, and high geothermal gradients, commonly linked to magmatic intrusion and volcanism, often give rise to many geothermal sites on the floors of rift basins. The sedimentary record of hydrothermal activity in rifts is preserved mainly as travertine, silica sinter and metal sulphide deposits, which precipitate in and around high-temperature springs associated with axial high-enthalpy geothermal systems. Most recharge of those hydrothermal reservoirs comes from precipitation falling on the rift floor and the elevated rift margins, which implies that the hot-spring discharge and any associated deposits may be related to climate variations. Sturchio et al. (1993), for example, showed that sinter deposits in the northern Kenya Rift formed mainly during late Pleistocene humid phases when the water table below the rift floor was regionally much higher than it is today. Many of the hot springs in continental rifts discharge along fault lines that define the margins of lakes that occupy parts of the rift floor. In semi-arid regions, such as much of the East African Rift (Tanzania, Kenya, Ethiopia and Djibouti), those lakes commonly lie in closed hydrological basins and fluctuate frequently in level and salinity in response to variations in climate. The changes in climate that affect lake levels can also affect hydrothermal spring discharge in the same rift basins over variable time scales. Shoreline hot springs, for example, may become submerged when lake levels rise, or become subaerially exposed when lake levels fall, perhaps accompanied by reduced spring discharge. This study examines these interrelationships using the example of high-temperature travertine formation at hot springs on the margin of Lake Bogoria in the central Kenya Rift Valley.

The Lake Bogoria hot springs are a major tourist attraction in the Lake Bogoria National Reserve, a recently designated (2011) UNESCO World Heritage Site. Many of the hot springs, geysers and fumaroles discharge near the shoreline at Loburu, a small delta on the western margin of Lake Bogoria, which is a perennial, closed, saline alkaline lake ('underfilled' in the sense of Bohacs et al., 2000) in a densely faulted catchment composed of Neogene volcanic rocks (McCall, 1967, 2010; Renaut \& Tiercelin, 1994). The lake experienced many changes in level and salinity during the late Pleistocene and Holocene (Tiercelin \& Vincens, 1987).

Travertine is present at several Loburu hot springs. These carbonates differ, however, from those at other well-known hot-spring travertine sites such as Pamukkale in Turkey (Özkul et al., 2002; Dilsiz et al., 2004; Pentecost, 2005), central Italy (Chafetz \& Folk, 1984; Guo \& Riding, 1998; Capezzuoli \& Gandin, 2005; Pentecost \& Coletta, 2007) and Mammoth Hot Springs at Yellowstone, USA (Chafetz \& Folk, 1984; Chafetz \& Guidry, 2003; Fouke, 2011). Most travertine at Loburu precipitated from waters with temperatures either at or close to boiling point ('thermogene springs' in the sense of Pentecost, 2005), and above water temperatures recorded for most springs where travertine forms. Furthermore, all the hot-spring vents lie within a few metres of local base level (i.e. mean lake level) rather than on valley-side slopes. As a result, their vents are periodically submerged by lake water and, at times, the hot-spring carbonates have been buried by deltaic sediments or encrusted by lacustrine calcite stromatolites. At other times, the travertine has formed subaerially or has been weathered.

High spring-fluid temperatures and their lakemargin setting have given the Loburu travertines some distinctive morphological and textural features that contrast with those at cooler hot springs. Renaut (1982) first described their morphology and petrography. Casanova $(1986,1994)$ assessed the role of bacteria in their formation. Jones \& Renaut (1995) explained some of their unusual crystal fabrics, but their morphosedimentary characteristics, depositional history, and the interrelationships among spring activity, lakelevel changes and travertine formation have not previously been considered.

In this study, the Loburu travertines are described in detail, including new stable isotope results and mineralogical data. The origin of the travertines is then reviewed, incorporating new ideas on the influence of lake-level fluctuations and changes in depth of boiling on their formation. Most travertines are shown to be sub-fossil (relict) deposits even though hot-spring waters still flow across the carbonate substrates. Evidence is then presented to show how climate change and tectonic adjustments, and their combined effects on lake level and spring and lake fluid compositions, periodically interact to create favourable conditions for thermogene travertine formation in continental rift basins. 


\section{GEOLOGICAL AND ENVIRONMENTAL SETTING}

Lake Bogoria occupies a narrow asymmetrical half-graben in the central Kenya Rift, ca $20 \mathrm{~km}$ north of the equator (Tiercelin \& Vincens, 1987; Fig. 1). The Bogoria Escarpment, up to $1700 \mathrm{~m}$ high, lies along a major north-south oriented normal fault that defines the eastern edge of the half-graben. A south-west virgation in that fault system towards a $\mathrm{N}^{\circ} 0^{\circ}$ trend provides the southern closure of the lake. The face of the steep faultscarp exposes Miocene to Pleistocene volcanic rocks (McCall, 1967; Griffiths, 1977; Hackman, 1988), with coalescent alluvial fans along most of its base.

West of the lake, Pleistocene phonolite and basalt flows that erupted on the rift floor upon older down-faulted volcanic rocks form the low- er-lying (ca $1500 \mathrm{~m}$ ) Bogoria Plateau (Griffiths, 1977; Clément et al., 2003). A network of late Pleistocene north-south trending grid-faults cut the plateau surface, which dips gently northwards (Fig. 1B and C). North of the lake, the dry Sandai Plain is composed of late Quaternary deltaic, alluvial and colluvial sediments. A north-west to south-east trending fault zone, the Waseges-Marmanet Transverse Zone, defines the northern limit of the present Bogoria drainage basin (Le Turdu et al., 1999). North of that structural zone lie the alluvial Loboi Plain and Lake Baringo - a fresh water lake also partly fed by hot springs (Tarits et al., 2006; Fig. 1B).

Modern hydrothermal activity is focused at three locations around Lake Bogoria (Cioni et al., 1992). Hot springs discharge on the mid-western shoreline at Loburu (Kiboriit) and Chemurkeu (Mawe Moto), and along the southern lake

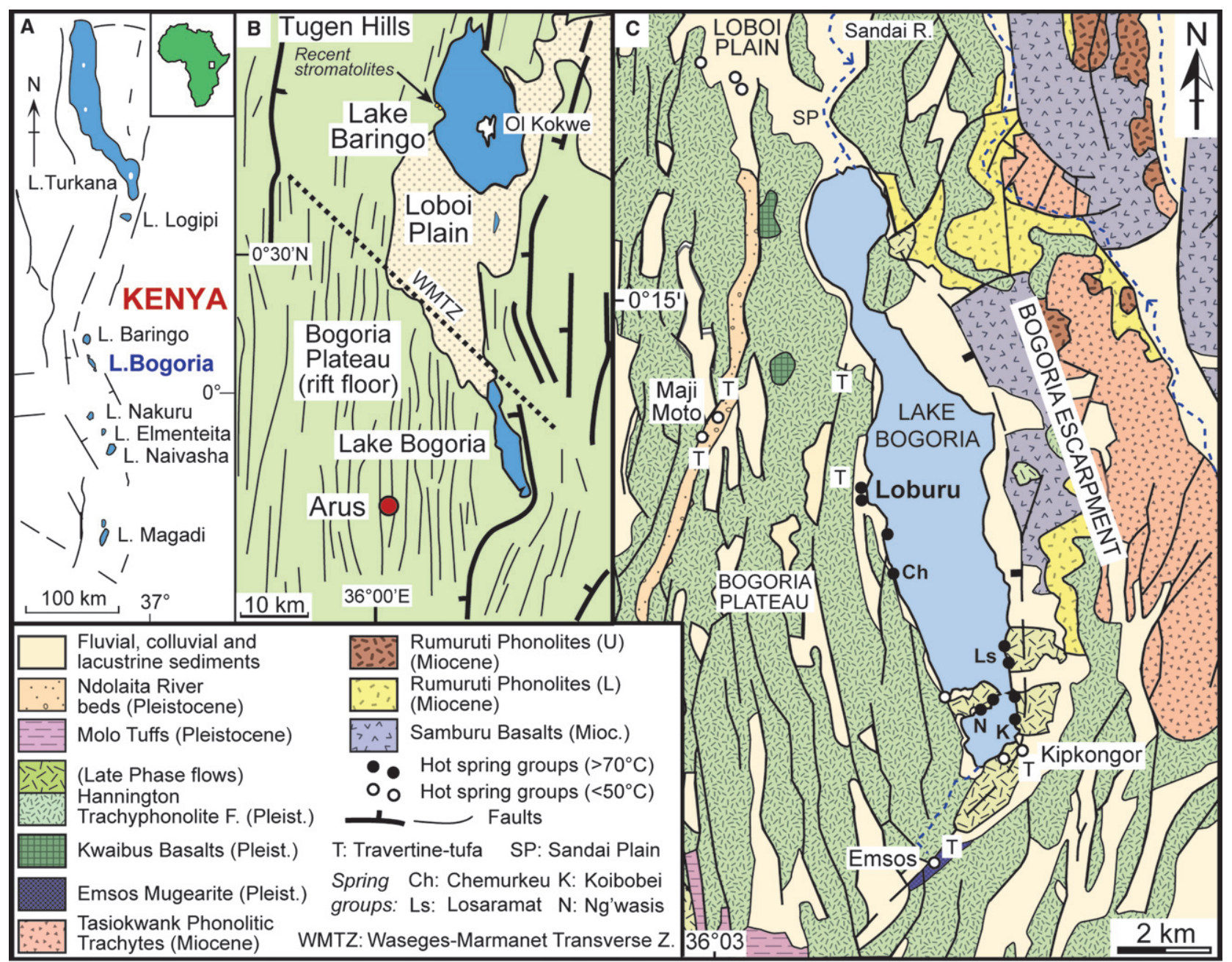

Fig. 1. Geological setting of the Loburu geothermal area. (A) Kenya Rift Valley. (B) Structural setting of Lake Bogoria and Lake Baringo. (C) Geological setting of Lake Bogoria and its geothermal sites [based on Griffiths (1977) and Hackman (1988)]. 
shorelines at Ng'wasis (Mwanasis), Koibobei (Kwaipopei) and Losaramat (Fig. 1C). The southern spring group is associated with faults and fracture zones at sites of the youngest volcanic rocks in the basin, which are dated at 0.5 to 0.7 Ma (Griffiths, 1977; Clément et al., 2003). Fossil travertine is present at Chemurkeu, where boiling springs flow from fissures in fractured phonolite along a rocky shoreline (Renaut \& Jones, 1997), but no travertine is present at the southern hot-spring group. Several large (up to $5 \mathrm{~m}$ thick) porous tufas, rich in moulds of macrophytes, leaves and wood, are present at sites of dilute hot springs near the lake at Maji Moto, Emsos and Kipkongor (Fig. 1C). The term 'tufa' is used here for limestones precipitated in cool, ambient and warm spring waters, characterized by many microphyte, macrophyte, bacterial and invertebrate remains (Ford \& Pedley, 1996).

The present climate is semi-arid. Annual precipitation on the rift floor is $c a 600$ to $900 \mathrm{~mm}$ per year, compared with an annual evaporation rate of $c a 2600$ to $2900 \mathrm{~mm}$ per year. Rainfall is seasonal with 'long rains' from April to August, and 'short rains' mainly in November. Daytime maximum air temperatures are typically 25 to $35^{\circ} \mathrm{C}$.

Lake Bogoria is a meromictic, saline (up to $90 \mathrm{~g} \mathrm{l}^{-1}$ TDS: total dissolved solids), alkaline ( $\mathrm{pH}$ : $10 \cdot 1$ to $10 \cdot 5$ ), closed-basin lake with $\mathrm{Na}-\mathrm{CO}_{3}-$ $\mathrm{HCO}_{3}-\mathrm{Cl}$ waters (Harper et al., 2003). The Sandai River, the warm-spring-fed Emsos River, ephemeral streams, direct rainfall and almost 200 hot springs recharge the lake (Renaut \& Tiercelin, 1994; Onyando et al., 2005). The lake level (ca $990 \mathrm{~m}$ ) fluctuates frequently over time spans ranging from years $( \pm 1 \mathrm{~m})$, to decades $( \pm 3 \mathrm{~m})$, to $10^{2}$ to $10^{3}$ years $( \pm 9 \mathrm{~m})$. Short-term fluctuations are influenced by El Niño and La Niña cycles (Johansson \& Svensson, 2002). Although always alkaline, the lake water salinity decreases by $>20 \%$ during brief periods (a few years) of higher lake level (Tiercelin \& Vincens, 1987; Renaut \& Tiercelin, 1994). During a mid to late Holocene phase of high lake levels and comparatively dilute waters, pale-grey stromatolitic limestone crusts up to $30 \mathrm{~cm}$ thick formed on firm substrates around the shoreline at up to $c a 997 \mathrm{~m}$ elevation (Vincens et al., 1986). These calcite stromatolites encrust travertines at Loburu and Chemurkeu, and volcanic rock substrates around the lakeshore.

Loburu, a small $\left(0.5 \mathrm{~km}^{2}\right)$ delta on the midwestern lakeshore, is bordered along its western margin by low (20 to $40 \mathrm{~m}$ high) faulted escarpments of phonolite. Three ephemeral streams created the delta. Most hot springs with travertine deposits lie in an interdistributary embayment between the two delta lobes (Figs 2 and 3A). Alkali-tolerant marsh, dominated by sedges (Cyperus laevigatus) but with grass (Sporobolus spicatus) in drier areas, is sometimes present in the embayment. The deltaic sediments are palebrown, bedded, fine sands, silts and muds, with ribbon (channel and beach) and sheet-like (littoral plain) interbeds of coarse K-feldspar sand and lithic gravel.

\section{THE ARUS-BOGORIA GEOTHERMAL SYSTEM}

The origin of the Bogoria geothermal fluids and the nature of the plumbing system are unresolved, although there is general agreement that the fluids derive mainly from infiltration of rain water falling locally on the flanks and floor of the rift. Glover (1972) proposed that the Loburu springs discharge slightly thermal, local ground water, which has been heated by steam and has mixed with some lake water during its ascent. Cioni et al. (1992), using chemical and stable isotope analyses, suggested that the Loburu fluids discharge from a shallow aquifer fed mainly by local dilute ground water $(88 \%)$. Added to this is a small fraction of lake water ( $\mathrm{ca} 3 \%$ ), which has mixed with steam derived from a deeper thermal upflow that condensed in the ground water after the deeper fluids had boiled ( $\mathrm{ca}$ 10\%). Karingithi \& Wambugu (2008) similarly favoured an origin mainly by steam heating of shallow local ground waters. In contrast, Allen et al. (1989) and Clarke et al. (1990) rejected steam heating of local ground water, and suggested that the Loburu fluids originate from a regional shallow ground water body that has been drawn directly into a 'hot $\mathrm{CO}_{2}$-rich upflow', which was not clearly defined. These authors proposed that the deeper fluids cool rapidly by adiabatic processes, with contamination by non-thermal dilute ground water or a small volume of lake water occurring at various depths in the thermal circulation. Hochstein (1999), in contrast, proposed an origin by advection or 'forced convection'. In this model, rain water falling on the elevated rift margins seeps down faults and fractures to great depth under its own hydrostatic head, where it is then heated on contact with hot rocks and rises to emerge on the rift floor. 


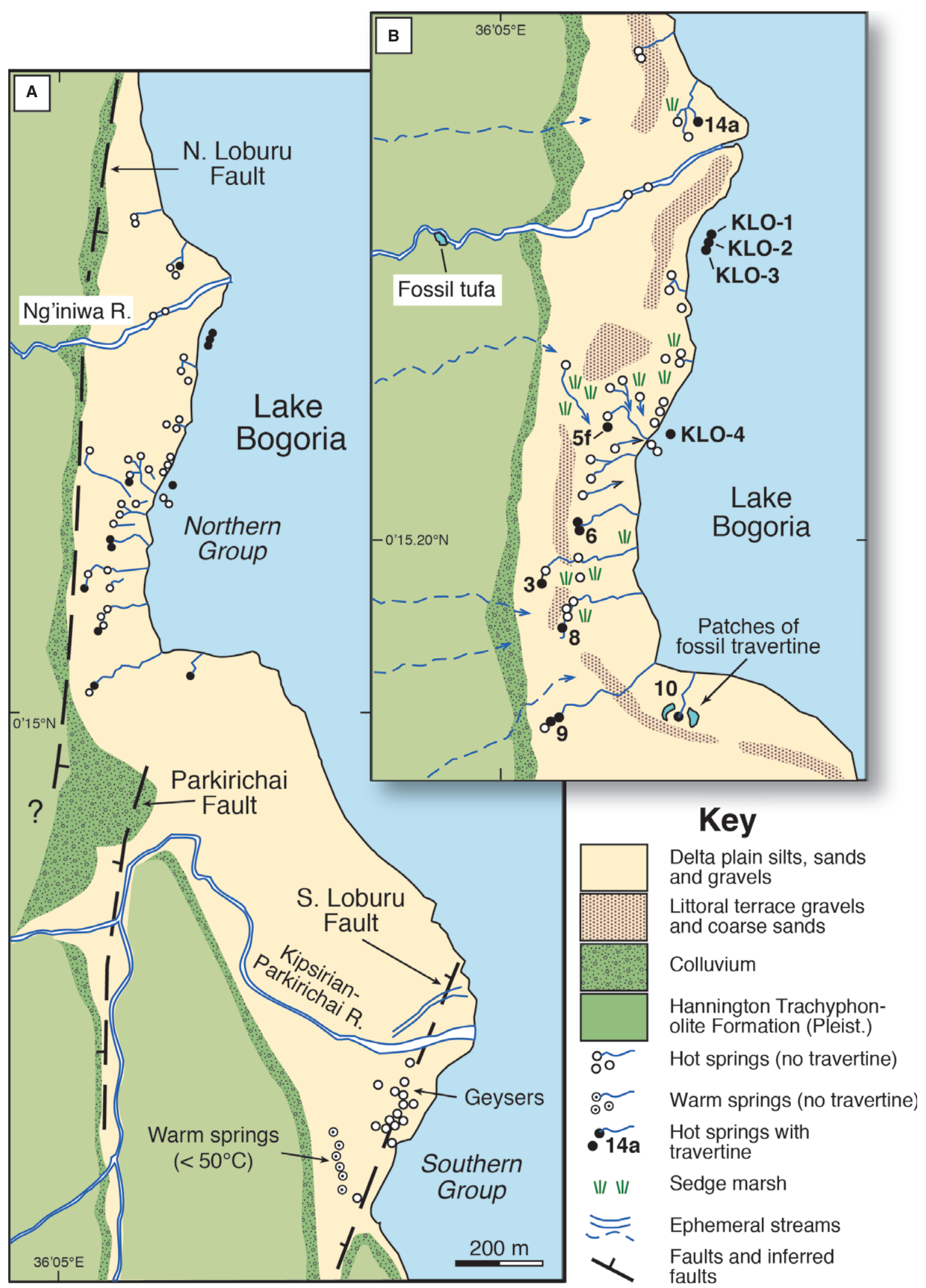

Fig. 2. Loburu delta showing the hot-spring distribution. (A) Plan of the delta showing the two main hot-spring groups aligned along north-south faults. (B) Locations of hot springs with exposed travertine deposits that are discussed in the text. The position and outline of the shoreline varies by $>100 \mathrm{~m}$ from year to year. 

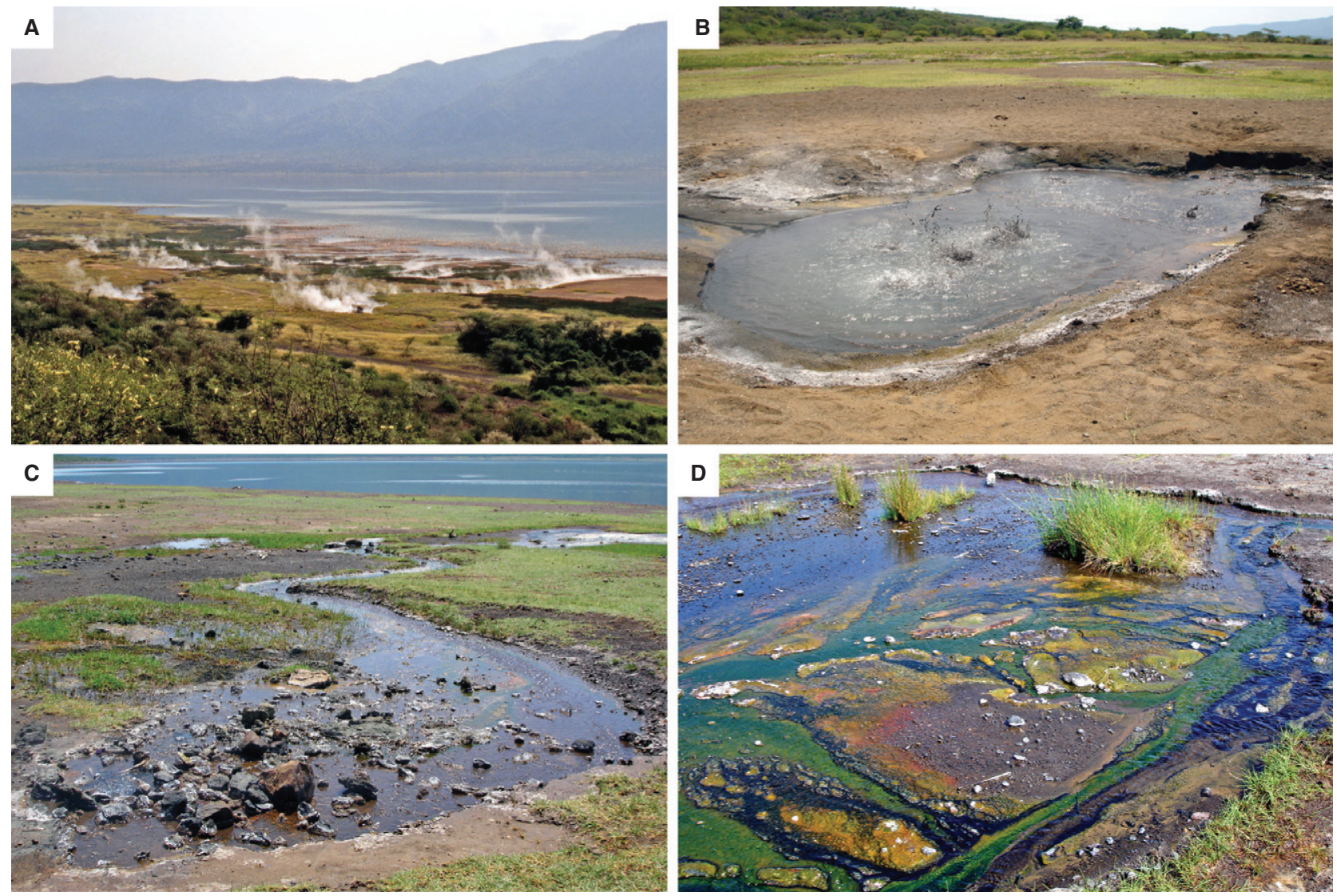

Fig. 3. Hot springs of the Loburu delta. (A) The interdistributary embayment, where most of the travertine hot springs are located. Bogoria Escarpment in background. Field of view across the delta (left to right) is $c a 1 \cdot 3 \mathrm{~km}$. (B) Spring KL5, a typical ebullient pool spring, ca $3.5 \mathrm{~m}$ in diameter. Efflorescent crusts of silica (opal-A) and Nacarbonate salts surround the pool margin, but travertine is absent. (C) Spring KL15, the northernmost spring at Loburu, is a seepage spring $c a 4 \mathrm{~m}$ in diameter without a vent pool. The spring has thin subaerial opaline silicatrona-thermonatrite crusts around the vent but no travertine. (D) Microbial mats in outflow channel network of spring KL14b, where $\mathrm{T}=\mathrm{ca} 40$ to $70^{\circ} \mathrm{C}$. Modern mats are unmineralized except thin surficial opal-A crusts produced by wicking, and $\mathrm{Na}-\mathrm{HCO}_{3}-\mathrm{CO}_{3}$ efflorescent salts on some exposed surfaces. Clump of sedges (Cyperus laevigatus) at the top right is $c a 75 \mathrm{~cm}$ across at its base.

Standard empirical geothermometers indicate reservoir temperatures of 150 to $190^{\circ} \mathrm{C}$ (Glover, 1972; Allen et al., 1989; Cioni et al., 1992; Hochstein, 1999; Karingithi \& Wambugu, 2008, 2010). Fractured volcanic rocks, palaeosols and permeable intravolcanic sediments are the main aquifers below the rift floor (McCall, 1957, 1967; Olago et al., 2009). The deep geothermal reservoirs below Bogoria may lie in fractured Miocene Samburu Basalts (Naylor, 1972), which lie at $c a$ $3.5 \mathrm{~km}$ depth below the Bogoria basin and Loboi Plain (Hautot et al., 2000), and are capped by phonolites (Rumuruti Formation) with low permeability. Dyke injection along faulted zones may be a magmatic heat source (Naylor, 1972; Mwawongo, 2006; Omenda, 2008), but Hochstein (1999) and Mulwa et al. (2006) suggested that crustal intrusions are not needed to supply the heat. Mulwa et al. (2006) proposed that the locus of regional geothermal upflow lies near Arus, where vigorous $\mathrm{CO}_{2}$-rich fumaroles discharge in a graben $14 \mathrm{~km}$ south-west of Lake Bogoria (Fig. 1B).

\section{METHODS}

Fieldwork took place on 12 occasions between June 1976 and July 2011, mainly during summer months (June through to August), but also in November 1991 and February 1994. Large thin sections of travertine samples were examined by standard petrographic methods using polarizing microscopes. Some textures were studied using polished thin sections on a JEOL JX8600 (JEOL Limited, Tokyo, Japan) electron microprobe in 
backscattered electron imaging mode. Scanning electron microscope (SEM) observations of $\mathrm{Au}$-coated samples were undertaken using Cambridge Stereoscan S250 (Cambridge Scientific Instrument Company, Ely, UK) and JEOL $840 \mathrm{~A}$ instruments with an accelerating voltage of $25 \mathrm{kV}$, and a JEOL 6301 FE-SEM at an accelerating voltage of 0 to $5 \mathrm{kV}$. All X-ray diffraction (XRD) analyses were performed with pressed powder mounts of finely ground samples using a Rigaku RU200 rotating-anode diffractometer (Rigaku Corporation, Tokyo, Japan) with a $\mathrm{Cu}$ source and scanning speeds of $0 \cdot 5^{\circ}$ or $1^{\circ} \min ^{-1}$.

Twenty-six travertine samples and four encrusting lacustrine stromatolites that had been examined petrographically were analysed for stable carbon and oxygen isotopes using a Finnigan MAT 251 mass spectrometer (Thermo Finnigan MAT GmbH, Bremen, Germany). Powdered samples from two blocks were extracted by dental drill. About $15 \mathrm{mg}$ of each powdered sample was placed in reaction vessels and atmospheric gases were then evacuated. After dissolution in $100 \% \mathrm{H}_{3} \mathrm{PO}_{4}$ at $25^{\circ}$ and cryogenic purification, the evolved $\mathrm{CO}_{2}$ was analysed for carbon and oxygen isotopes, which are reported using the standard delta notation relative to the Vienna Peedee Belemnite (Craig, 1957).

Water samples were collected in polypropylene bottles and then triple-sealed in plastic film. Field $\mathrm{pH}$ was determined using several generations of Orion (Thermo Orion, Beverly, MA, USA) and VWR pH meters (VWR International, Radnor, PA, USA), each calibrated in the field during the morning of sample collection using $\mathrm{pH} 7 \cdot 0$ and 10.01 standards. Water temperatures were measured using several types of VWR maximum-minimum digital probe thermometers, and a QuikSite 900LS infrared thermometer (H-B Instrument Company, Trappe, PA, USA). After field filtration through 0.45 micron syringe filters, all water samples were analysed within two to five weeks of collection (depending on airfreight time) by atomic absorption spectrometry (major ions), ion chromatography $\left(\mathrm{SO}_{4}\right)$ and ionspecific electrodes (Cl, F). Alkalinity $\left(\mathrm{CO}_{3}\right.$, $\mathrm{HCO}_{3}$ ) was determined by titration 5 to $40 \mathrm{~min}$ after sample collection and in the laboratory. Field alkalinity determinations are reported. Water-sample analytical results were tested using SOLMINEQ88 (Kharaka et al., 1988) to confirm that their cation/anion balance was $<10 \%$ (most are $<5 \%$ ), and to calculate $\mathrm{PCO}_{2}$ and mineralsaturation indices.

\section{RESULTS}

\section{The Loburu hot springs}

\section{Distribution and physical characteristics}

The Loburu hot springs form two linear groups, each aligned along north-south trending normal faults that cut the phonolites west of the delta (Fig. 2A). The northern group consists of $c a 32$ individual hot-spring vents, whereas the southern group comprises ca 25 vents. For the past 30 years, the highest active springs have been $c a$ 75 to $100 \mathrm{~cm}$ above the mean lake level ( $\mathrm{ca}$ $990 \mathrm{~m}$ ). The number of subaerial vents varies with prevailing lake level: those nearest the shoreline are periodically submerged but continue to discharge hot fluids subaqueously offshore. During unusually wet years, such as the El Niño event of 1997 and 1998 and heavy rains in 2010, most spring vents are flooded; in dry years (for example, July, 2006), several vents that are normally submerged become subaerially exposed.

Three groups of springs are recognized: pool springs, seepage springs and springs with travertine deposits (described separately below). Most springs flow from well-defined vent pools, $30 \mathrm{~cm}$ to $c a 10 \mathrm{~m}$ in diameter (Fig. 3B). Pools near the shoreline are typically shallow $(<50 \mathrm{~cm}$ deep) and bordered by littoral siliciclastic sediments and (or) marsh vegetation. Near the fault scarp, many pools are entrenched up to $c a 1 \mathrm{~m}$ in the deltaic sediments. Some have steep plunging margins. Pool spring floors are $<20 \mathrm{~cm}$ to at least $2 \mathrm{~m}$ deep, based on plumb line measurements, and most have unconsolidated silts and sands on their floors. Water from pool springs flows through narrow (10 to $100 \mathrm{~cm}$ wide), shallow (2 to $30 \mathrm{~cm}$ deep), low-sinuosity outflow channels into the lake, other spring pools or littoral wetlands. Channel alignments change frequently with lakelevel fluctuations except near the scarp, where channels are incised in the deltaic sediments.

Seepage springs lack a vent pool. Some discharge quietly from marshy ground or deltaic sediments; others flow from littoral gravel (Fig. 3C). Springs flowing from marsh usually have low discharge $\left(<0.3 \mathrm{l} \mathrm{sec}^{-1}\right)$ and are 5 to $10^{\circ} \mathrm{C}$ cooler than pool springs, whereas those seeping from gravel commonly have higher discharge $\left(<0 \cdot 5 \mathrm{l} \mathrm{sec}^{-1}\right)$ and temperatures $(\mathrm{T})>94^{\circ} \mathrm{C}$.

The Loburu spring waters have maximum vent temperatures of 43 to $97 \cdot 5^{\circ} \mathrm{C}$, the latter value being boiling point for the altitude and salinity. Most springs have temperatures $>90^{\circ} \mathrm{C}$ at their vents. The largest pool springs are boiling and 
highly ebullient. Some surge every 4 to $5 \mathrm{~min}$ accompanied by an increased gas flux; others display 'bubble shower' activity (see Bryan, 2005) with periodicities of $<30 \mathrm{sec}$. At least six geysers were active in the southern Loburu group between 1976 and 2009 (Fig. 2A). Small pool springs flow continuously but less vigorously. Some seepage springs become dry during periods of relatively low lake level. Cioni et al. (1992) estimated the total spring water discharge at Loburu to be $650 \mathrm{l} \mathrm{sec}^{-1}$, representing $c a 70 \%$ of all the subaerial hot-spring inflow to the lake.

Microbial mats are present at most springs where the water temperature is $<70^{\circ} \mathrm{C}$ (Fig. 3D). These include the wetted margins of most pool springs and their outflow channels, and subaqueous parts of outflow channels where the water has cooled to $<70^{\circ} \mathrm{C}$. The mats are variably composed of Oscillatoria, Phormidium, Spirulina, Pseudanabaena, Synechococcus and Chloroflexus (Grant \& Tindall, 1986; Hindák, 2001; Krienitz et al., 2003, 2005), with diatoms common in cooler spring locations. Most mats lack mineralization, except local silicification by opal-A at sites where evaporation occurs at or slightly above water level.

Thin white efflorescent crusts of thermonatrite, trona, nahcolite, halite and opaline silica commonly line the subaerial margins of many springs and their proximal outflow channels. Subaqueous silica polymerization generally is absent, although soft, bluish grey, silica gels form occasionally in shallow ( $<1 \mathrm{~cm}$ deep) ponded water with little flow at spring KL14 (Fig. 2B) and in a few other places.

\section{Hydrochemistry}

The Loburu hot springs discharge alkaline $\mathrm{Na}-$ $\mathrm{HCO}_{3}-\mathrm{Cl}$ waters. The $\mathrm{pH}$ at the spring vents is typically between 8.3 and 8.9 (mean of 266 measurements made at different times from July 1977 to July 2011: 8.68, with an absolute range of $7 \cdot 7$ to $9 \cdot 5)$. The salinity is 4.5 to $5.5 \mathrm{~g} \mathrm{l}^{-1}$ TDS (Table 1). The waters are low in alkaline earths (Ca: $<1.7 \mathrm{mg} \mathrm{l}^{-1}$; Mg: $<1.0 \mathrm{mg} \mathrm{l}^{-1}$ ), high in fluoride (up to $85 \mathrm{mg} \mathrm{l}^{-1}$ ) and are undersaturated with respect to amorphous silica at the sites of surface discharge $\left(\mathrm{SiO}_{2}\right.$ : 90 to $128 \mathrm{mg} \mathrm{l}^{-1}$; mean: $106 \mathrm{mg} \mathrm{l}^{-1}: n=40$ ).

The spring waters contain ca $220 \mathrm{mg} \mathrm{l}^{-1} \mathrm{Cl}$, compared with 10 to $75 \mathrm{mg} \mathrm{l}^{-1} \mathrm{Cl}$ in local dilute ground waters (Dunkley et al., 1993; Karingithi \& Wambugu, 2008), and up to ca $10000 \mathrm{mg} \mathrm{l}^{-1} \mathrm{Cl}$ in the lake water. Waters sampled at the vents maintain similar ionic ratios across the delta, implying a common fluid source. A few small springs with low discharge near the shoreline, including those that flow from offshore travertine mounds, have higher than average salinities of up to $10 \cdot 7 \mathrm{~g} \mathrm{l}^{-1}$ TDS. This increase can be attributed to shallow mixing of the rising spring fluids with the saline lake water (see Holzbecher, 2005).

Several springs and the geysers surge with a very high gas flux, most evident where ebullient waters discharge at the surface with temperatures below local boiling point. $\mathrm{CO}_{2}, \mathrm{~N}_{2}$ and $\mathrm{CH}_{4}$ are the main non-condensable gases that accompany the steam (Glover, 1972; Cioni et al., 1992). $\mathrm{H}_{2} \mathrm{~S}$ was below detection limit in gas analyses of Loburu springs by Cioni et al. (1992), who suggested that it is absorbed in shallow ground water during upflow of the geothermal fluids.

The hot-spring waters contain $<1 \cdot 7 \mathrm{mg} \mathrm{l}^{-1} \mathrm{Ca}$. Nevertheless, modelling the fluid compositions of analysed samples taken over 33 years using SOLMINEQ88 (Kharaka et al., 1988) shows that most are usually saturated with respect to calcite.

Table 1. Chemical analyses of hot-spring and lake waters at Lake Bogoria.

\begin{tabular}{|c|c|c|c|c|c|c|c|c|c|c|c|c|c|c|}
\hline Sample & Date & $\begin{array}{l}\mathrm{T} \\
\left({ }^{\circ} \mathrm{C}\right)\end{array}$ & $\begin{array}{l}\mathrm{pH} \\
\text { (field) }\end{array}$ & $\begin{array}{l}\mathrm{Na} \\
\mathrm{mg} \mathrm{l}^{-1}\end{array}$ & $\begin{array}{l}\mathrm{K} \\
\mathrm{mg} \mathrm{l}^{-1}\end{array}$ & $\begin{array}{l}\mathrm{Ca} \\
\mathrm{mg} \mathrm{l}^{-1}\end{array}$ & $\begin{array}{l}\mathrm{Mg} \\
\mathrm{mg} \mathrm{l}^{-1}\end{array}$ & $\begin{array}{l}\mathrm{HCO}_{3} \\
\mathrm{mg} \mathrm{l}^{-1}\end{array}$ & $\begin{array}{l}\mathrm{CO}_{3} \\
\mathrm{mg} \mathrm{l}^{-1}\end{array}$ & $\begin{array}{l}\mathrm{Cl} \\
\mathrm{mg} \mathrm{l^{-1 }}\end{array}$ & $\begin{array}{l}\mathrm{SO}_{4} \\
\mathrm{mg} \mathrm{l}^{-1}\end{array}$ & $\begin{array}{l}\mathrm{F} \\
\mathrm{mg} \mathrm{l}^{-1}\end{array}$ & $\begin{array}{l}\mathrm{SiO}_{2} \\
\mathrm{mg} \mathrm{l}^{-1}\end{array}$ & $\begin{array}{l}\mathrm{Li} \\
\mathrm{mg} \mathrm{l}^{-1}\end{array}$ \\
\hline KL6 & Jul 1995 & $97 \cdot 5$ & $8 \cdot 20$ & 1420 & $15 \cdot 3$ & $0 \cdot 85$ & $0 \cdot 34$ & 2965 & - & 235 & $63 \cdot 5$ & $63 \cdot 5$ & 112 & $0 \cdot 55$ \\
\hline KL8 & Jul 1995 & $97 \cdot 0$ & $8 \cdot 55$ & 1350 & $14 \cdot 5$ & $1 \cdot 02$ & $0 \cdot 43$ & 3055 & - & 220 & $61 \cdot 5$ & $63 \cdot 0$ & 108 & $0 \cdot 61$ \\
\hline KL14a & Jul 1995 & $94 \cdot 0$ & $8 \cdot 35$ & 1480 & $19 \cdot 5$ & $0 \cdot 80$ & $0 \cdot 40$ & 3075 & - & 238 & 71 & $74 \cdot 2$ & 92 & $0 \cdot 62$ \\
\hline KL21 & Feb 1994 & $96 \cdot 5$ & $8 \cdot 80$ & 1395 & $19 \cdot 0$ & $0 \cdot 78$ & $0 \cdot 22$ & 3020 & - & 240 & 65 & $57 \cdot 4$ & 111 & $0 \cdot 67$ \\
\hline KLO-2 & Aug 2006 & $81 \cdot 5$ & $8 \cdot 84$ & 3560 & $57 \cdot 0$ & $0 \cdot 40$ & $<0 \cdot 1$ & 4430 & 1720 & 818 & 69 & $82 \cdot 5$ & 130 & - \\
\hline $\mathrm{CH}-2$ & Jul 1995 & $96 \cdot 5$ & $8 \cdot 75$ & 1700 & $34 \cdot 1$ & $0 \cdot 71$ & $0 \cdot 32$ & 2950 & 330 & 315 & 60 & $73 \cdot 0$ & 128 & - \\
\hline Maji Moto* & 1985-1987? & $36 \cdot 5$ & $7 \cdot 14$ & 113 & $12 \cdot 4$ & $6 \cdot 61$ & $1 \cdot 12$ & 300 & - & $8 \cdot 9$ & $10 \cdot 6$ & $4 \cdot 4$ & - & $0 \cdot 06$ \\
\hline $\begin{array}{l}\text { Lake } \\
\text { Bogoria }\end{array}$ & Jul 2005 & $27 \cdot 6$ & $10 \cdot 15$ & 26500 & 478 & $3 \cdot 7$ & $1 \cdot 05$ & 19600 & 21800 & 5720 & 160 & 585 & 227 & - \\
\hline
\end{tabular}

All springs are at Loburu except CH-2, a small geyser at northern Chemurkeu, and Maji Moto, a small dilute spring west of Lake Bogoria. All analyses are original except Maji Moto ( ${ }^{*}$ from Cioni et al., 1992). Travertine is present at all these springs except KL21, a pool spring.

(C) 2012 The Authors. Journal compilation () 2012 International Association of Sedimentologists, Sedimentology, 60, 428-468 


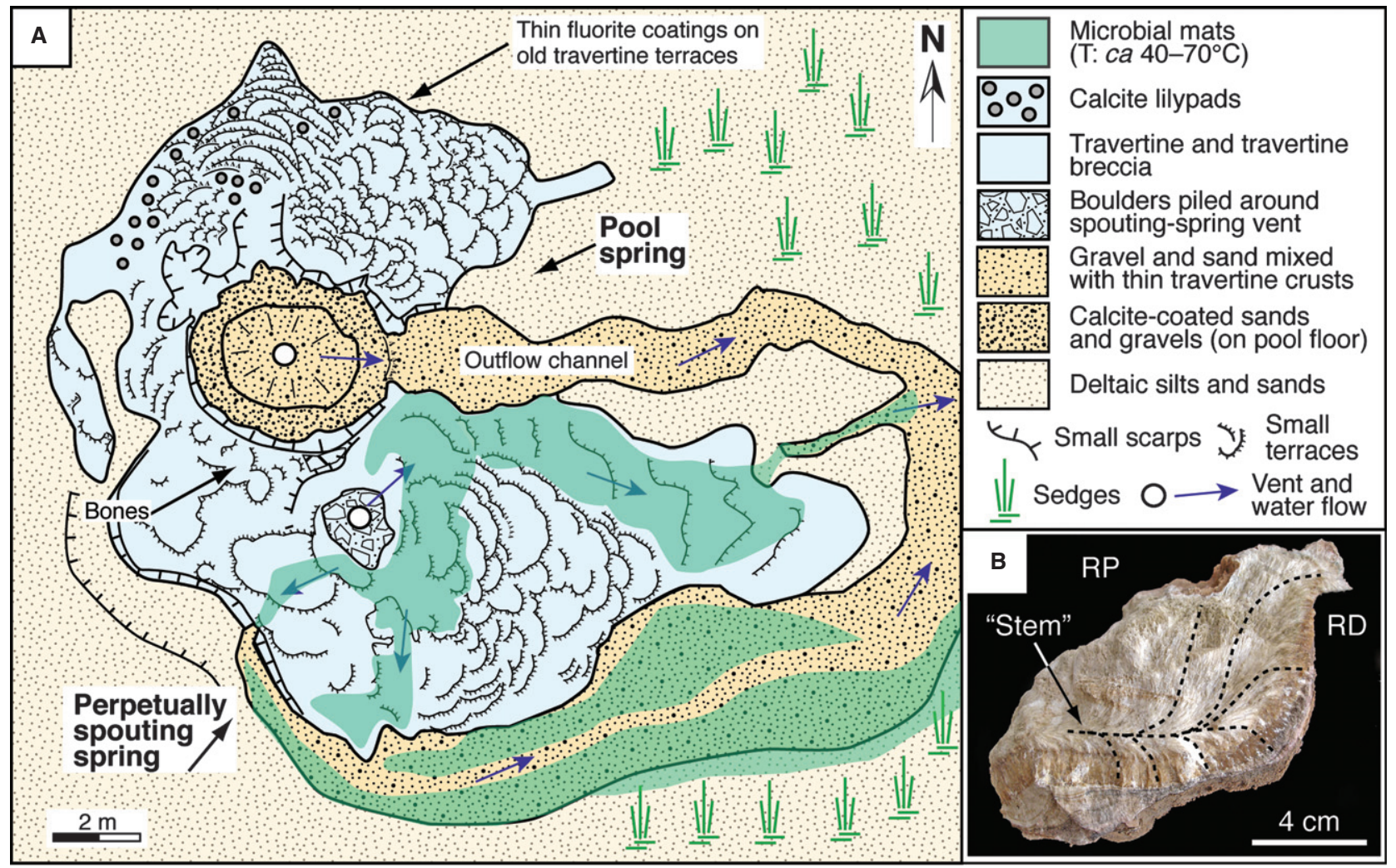

Fig. 4. Spring KL6, Loburu. (A) Plan of the spring (August 2006). (B) Cross-section through rimstone dam travertine showing the relationship of the calcite dendrites to the dam structure. The main calcite 'stem' is horizontal, with dendrite branches growing both upwards and downwards (indicated by dashed lines). 'RD' external face of the rimstone dam; 'RP' rimstone pool (unfilled).

The calculated calcite saturation indices range from -0.45 to $+1 \cdot 09$ (mean $=+0 \cdot 28 ; n=29)$. The calculated $\log \mathrm{PCO}_{2}$ of the modern spring vent water ranges from -3.21 to -0.90 (mean log $\mathrm{PCO}_{2}=-1 \cdot 94, n=40$ ). The thermal springs with tufa deposits at Maji Moto, Emsos and Kipkongor (Fig. 3C) are cooler $\left(32\right.$ to $\left.47^{\circ} \mathrm{C}\right)$, more dilute $(0 \cdot 4$ to $0.9 \mathrm{~g} \mathrm{l}^{-1}$ TDS) and contain more calcium ( 4.5 to $18 \mathrm{mg} \mathrm{l}^{-1} \mathrm{Ca}$ ) than the travertine springs at Loburu.

\section{Loburu travertines}

Travertine is visible at 11 of the hot springs (Fig. 2). Carbonates may be present at other springs, but are buried below deltaic sediments. Springs KL6, KL8 and KL5f, which are described here, have the most extensive travertine deposits. Spring numbers with the prefix KL (KiboriitLoburu) follow those of Renaut (1982).

Fig. 5. Travertine deposits at spring KL6, Loburu. (A) View from escarpment west of the springs shows the travertine-rimmed pool spring (left) and spouting spring and mound (right). Field of view (left to right) at the base of the photograph is $c a 25 \mathrm{~m}$. Photograph taken in June 2001 when the lake level was relatively high. In July 2006, the shoreline was $c a 200$ m away from the vents. In July 2011, both springs were submerged, but the spring jet continued to discharge offshore. The arrow points to a narrow ridge of travertine that is part of an old outflow channel (inverted topography). (B) Small, low rimstone terraces north-east of the pool spring; hammer (30 cm long) for scale. (C) Hemispheroidal travertine at the margin of the spring pool where $\mathrm{T}>90^{\circ} \mathrm{C}$. The knobby and spicular surface ornamentation characterizes zones of water oscillation (waves). Lens cap diameter is $52 \mathrm{~mm}$. (D) Calcite-encrusted mammal and bird bones on the margin of a spring pool. (E) Rimstone dams on the eastern edge of a spring mound. Rimstone pool floors commonly lack travertine substrates and are floored by unconsolidated gravel (phonolite and travertine clasts), giving terraces a 'skeletal' appearance. (F) Very thick (up to $7 \mathrm{~cm}$ ) microbial mats in outflow from the spouting spring. Water in the channel (centre) has $\mathrm{T}>80^{\circ} \mathrm{C}$ and is floored by thin recent crust of platy calcite and Mg-silicates. (G) Dense clusters of spicules composed of calcite and opal-A in a proximal outflow channel where water $\mathrm{T}>85^{\circ} \mathrm{C}$. The spicular morphology contrasts with the smooth, subaqueous, domal calcite crusts on adjacent channel floor. Scale bars apply only to the bottom (proximal) part of each photograph. 

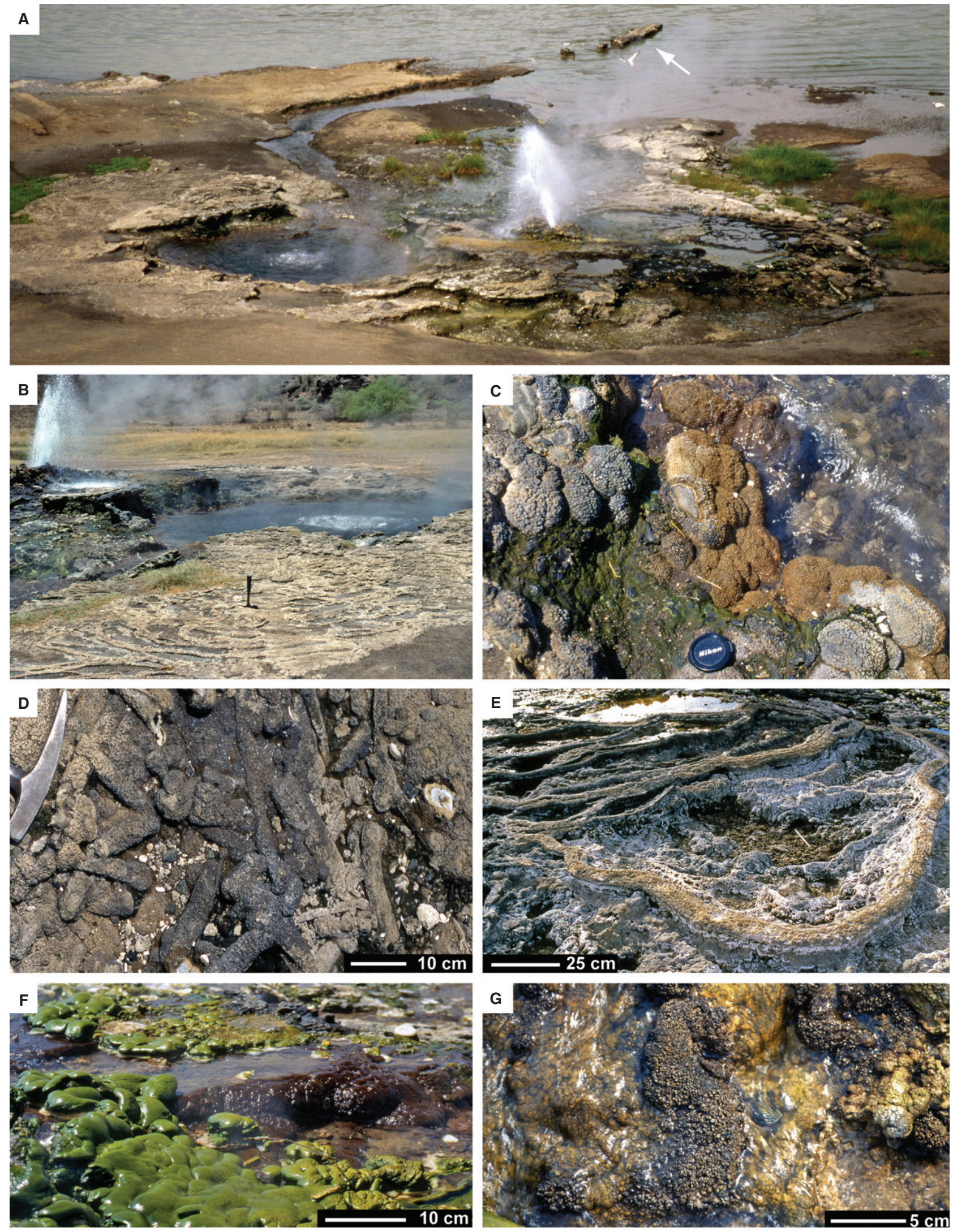


\section{Spring KL6}

Spring KL6 has the most extensive travertine deposits at Loburu. Boiling water $\left(\mathrm{T}: 97 \cdot 5^{\circ} \mathrm{C}\right.$ ) discharges continuously from a travertinerimmed pool next to a low terraced mound from which a jet of water and steam erupts constantly up to $3 \mathrm{~m}$ in the air (Figs 4 and $5 \mathrm{~A}$ ). The mound spring was reputedly once a geyser, but has been a perpetual spouter (sensu Bryan, 2008) since the 1970s or earlier. Trampling by visitors has badly damaged the travertine.

The nearly circular pool is $c a 5 \mathrm{~m}$ in diameter and at least $2 \mathrm{~m}$ deep. The water surface normally lies 50 to $80 \mathrm{~cm}$ below the travertine rim depending on the prevailing lake level. The ebullient spring water flows continuously into the lake through a narrow $(0.5$ to $1.5 \mathrm{~m})$, shallow $(<10 \mathrm{~cm}$ deep) outflow channel. Travertine forms a grey, discontinuous, weathered and eroded pool-rim dam up to at least $40 \mathrm{~cm}$ thick around the pool margins. North and east of the pool, a gently sloping ( 3 to $7^{\circ}$ ) platform of small terraces records former directions of outflow (Fig. 5B), when water spilled over the rim. Those terraces are composed of low (0.5 to $3 \mathrm{~cm}$ high $\times 1$ to $2 \mathrm{~cm}$ wide) rimstone dams that enclosed pools up to $1.5 \mathrm{~m}$ long $\times 1.2 \mathrm{~m}$ wide. The rims have an unusual ropy appearance. Small (3 to $10 \mathrm{~cm}$ diameter, 1 to $2 \mathrm{~cm}$ thick) calcite lilypads and a few pisoids $(<2 \mathrm{~cm}$ diameter) are present in some proximal pools of the platform.

In places, fractured blocks from the rim have slumped into the pool. Below the rim, grey and pale-brown, hemispheroidal, laminated travertine crusts, up to $5 \mathrm{~cm}$ thick, cover the substrate of deltaic sands and silts. These domal crusts, with basal diameters from 5 to $30 \mathrm{~cm}$, lie at recent levels of the pool water oscillation, but extend up to $c a 25 \mathrm{~cm}$ above and below water level (Fig. 5C). Many appear fresh and are probably younger than the pool-rim dam. Calcite-encrusted mammal and bird bones, some silicified, are cemented to the floor of small proximal rimstone pools adjacent to the dam (Fig. 5D). A narrow $(<15 \mathrm{~cm})$, discontinuous zone of microbial mats surrounds the pool margin in sites continuously moist from steam or spray, but mats are absent below pool water level.

The terraced mound, $c a 12 \mathrm{~m}$ in diameter, rises $c a 50 \mathrm{~cm}$ above the delta plain. Spray from the spring jet is directed north-eastwards (July 2011). Small blocks of phonolite and travertine that have been artificially piled around the vent have remained uncemented for at least 35 years.
The mound is composed of small overlapping terraces, each composed of arcuate rimstone dams and pools; most lie south and east of the vent. The dams, which are 5 to $10 \mathrm{~cm}$ thick and up to $25 \mathrm{~cm}$ wide at their base, are composed of coarse (centimetre-scale) calcite dendrites or thin bands and laminae of calcite crystals (Fig. 4B). Sub-horizontal laminated crusts (1 to $2 \mathrm{~cm}$ thick) and small knobs or ridges of calcite cover the floors of some rimstone pools. Many pool bases, however, have no precipitated carbonate and are floored by fine gravel, giving the terrace pools a 'skeletal' appearance with a rimstone framework but the absence of a fill (Fig. 5E).

The proximal terraces around the vent are often covered by green and orange, gelatinous bacterial mats up to $7 \mathrm{~cm}$ thick, composed of green non-sulphur bacteria (Chloroflexus) and cyanobacteria (Synechococcus and Oscillatoria), and other unknown genera. Cyanobacterial mats also cover pool and rimstone surfaces in areas of nearly continuous moisture, including zones of distal spray and outflow paths across terrace surfaces where the water temperature is $<70^{\circ} \mathrm{C}$ (Fig. 5F). No mats are visible where very hot $\left(>75^{\circ} \mathrm{C}\right)$ spray falls upon the substrate. The dark to purplish brown travertine surface in the proximal spray zone is covered locally by clusters of spicules. The spicules, each up to $5 \mathrm{~mm}$ high and $2 \mathrm{~mm}$ in diameter, are composed of calcite and (or) opal-A. Similar spicules are seen on the tops of rimstone dams near the vent at sites where water flows across the dam edge, and at partly subaerial sites where shallow waves oscillate across the surface (Fig. 5G).

Eroded remnants of travertine lie on weakly cemented sandy siltstones directly east of the pool spring next to the modern outflow channel, up to $20 \mathrm{~m}$ from the vents. This travertine, which was submerged and buried by deltaic sediments in the 1970s, is part of an older outflow system (Fig. 5A). The channel travertine, which has a rippled appearance, consists of low (1 to $2 \mathrm{~cm}$ high) rimstone dams and pool crusts, with small $(<1.5 \mathrm{~cm})$ pisoids and intraclasts $(<2 \mathrm{~cm})$ cemented to the pool floors.

Stratigraphic relationships and terrace pool orientations imply that the pool spring is the older vent, having discharged sheets of water over the pool-rim dam and across the small terraces towards the lake. The younger mound-spring travertine has since overstepped the southern rim of the pool. 


\section{Spring KL8}

At Spring KL8, a group of mounds up to $1.5 \mathrm{~m}$ high lie next to a broad shallow pool and proximal outflow channel, both floored by sub- aqueous travertine crusts and shallow terraces (Figs 6 and 7). Eroded mounds and ridges around the southern margins of the spring are evidence of an older, more extensive, travertine deposit.
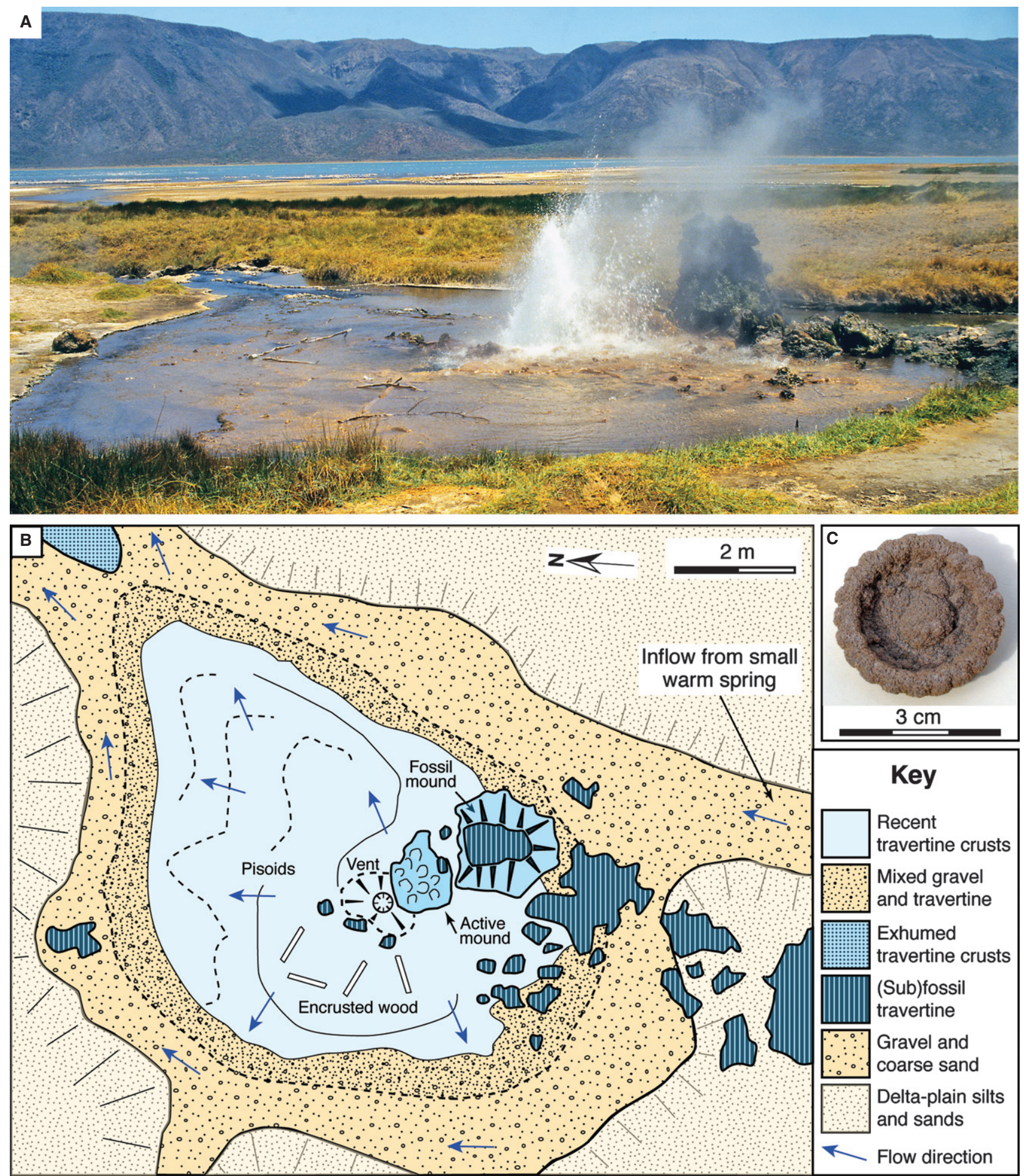

Fig. 6. Spring KL8, Loburu. (A) General view (February 1994) and (B) a plan of the spring and its travertine deposits. The dark mound right (south) of the vent is ca 1.5 high. (C) Tusker@ beer-bottle cap (East African Breweries Limited, Nairobi, Kenya) (confirmed by later calcite dissolution in $\mathrm{HCl}$ ) encrusted by platy calcite (ca 2 mm thick), removed from pool floor.

(C) 2012 The Authors. Journal compilation () 2012 International Association of Sedimentologists, Sedimentology, 60, 428-468 

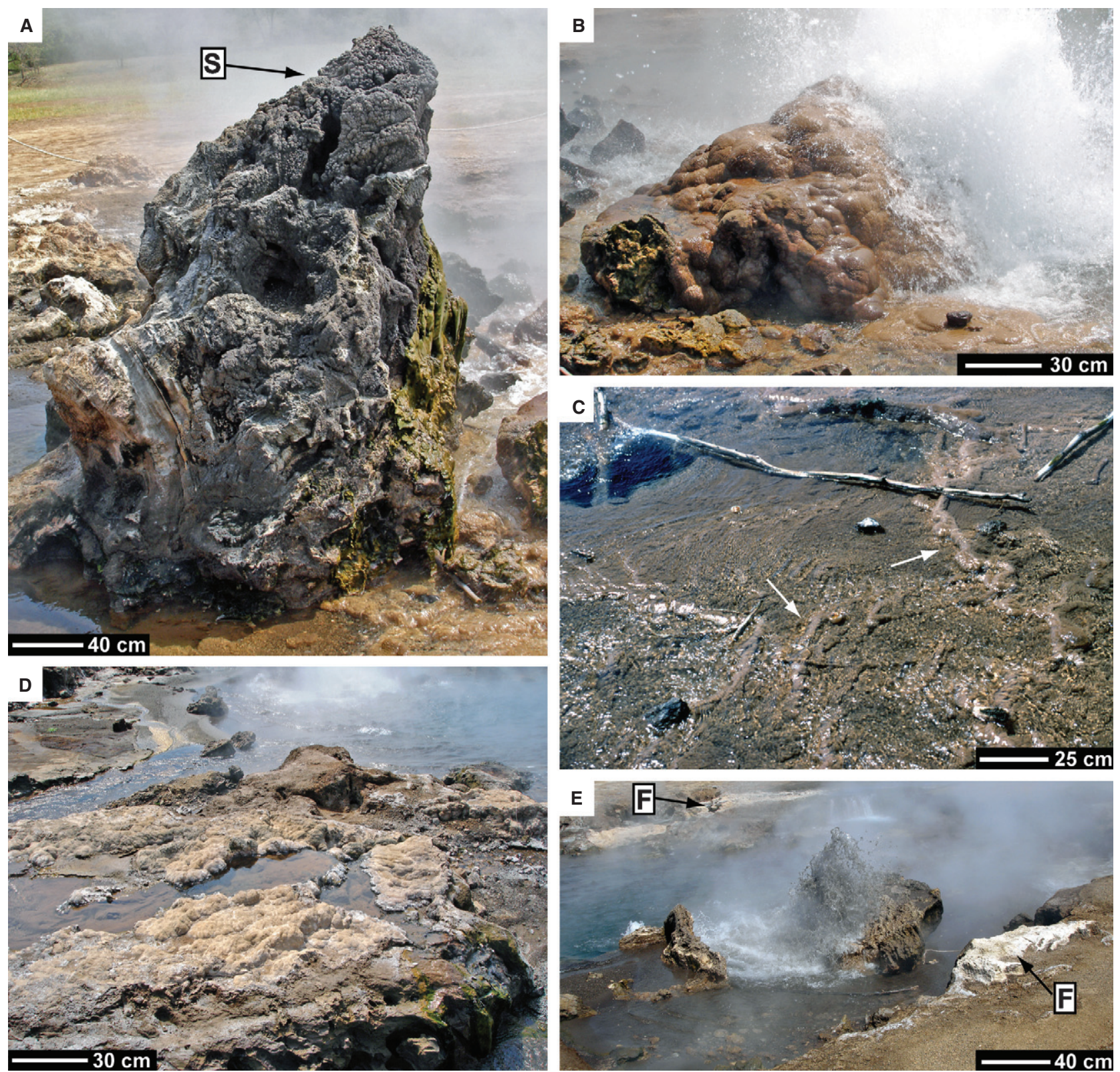

Fig. 7. Travertine at spring KL8, Loburu. (A) Eroded fossil travertine-mound showing steeply dipping crystal beds unrelated to present mound morphology. Lacustrine, hemispheroidal stromatolite crusts ' $\mathrm{S}$ ' cap the mound. (B) Modern domal travertine-mound in the spray zone (T: 85 to $98^{\circ} \mathrm{C}$ ) of active boiling spring-jet. The fresh, pale-brown calcite has mini-terraces on its surface. The mound might be rooted upon older travertine (?). (C) Modern pale-brown travertine crust forming spring-pool platform where water temperature is $c a 75$ to $95^{\circ} \mathrm{C}$. Arrows indicate encrusted Acacia twigs. (D) Recently (post-2001) exhumed relict travertine crusts adjacent to the modern outflow channel (top of photograph). (E) Highly ebullient spring $\left(\mathrm{T}>97^{\circ} \mathrm{C}\right)$ in outflow channel of spring KL8. Explosive (gas-rich) activity at this vent during the past decade disrupted relict travertine crusts and exposed older, buried fossil travertines (F). Scale bars apply only to the bottom (proximal) parts of each photograph.

This perpetually spouting spring ejects boiling water up to $3 \mathrm{~m}$ in the air from a travertinerimmed, funnel-shaped vent $1.5 \mathrm{~m}$ north of the largest mound. A subsidiary mound and several smaller mounds with mammillary surfaces lie $0 \cdot 5$ to $2 \mathrm{~m}$ east and south of the vent and receive spray from the spring jet. The largest mound is dark grey and brown, and strongly weathered. Internally, it is composed of sub-vertical and variably sloping beds, 1 to $10 \mathrm{~cm}$ thick, of light to dark brown, coarsely crystalline calcite. Most beds are truncated and show little relation to the

(C) 2012 The Authors. Journal compilation (ㄷ 2012 International Association of Sedimentologists, Sedimentology, 60, 428-468 
external form of the mound (Fig. 7A). In contrast, the smaller domal mound next to the vent is palegreyish brown with smooth surfaces, and has centimetre-scale mini-terraces on its steepest surfaces (Fig. 7B). To avoid visible damage, this mound was not sampled, but its fresh appearance and location imply that it is a site of active calcite precipitation from falling spray.

The travertine that forms the pool floor platform is composed of thin calcite beds ( 1 to $5 \mathrm{~cm}$ ) that encrust deltaic sediments. The pale-brown crusts generally are horizontal, but their upper surfaces commonly are formed of low-amplitude $(<1 \mathrm{~cm}$ high) hemispheroids. Small, low rimstone pools and dams are present near the sloping margins of the platform. The pool surface is littered by calcite-encrusted debris (Fig. 7C) including twigs, leaves, bones, anthropogenic debris (Fig. 6C) and volcanic gravel, some of which have become coated grains (pisoids). Much of this debris is cemented to the pool substrate.

The proximal outflow channel is floored by rimstone dams and pools, composed of palebrown, hemispheroidal calcite crusts up to $3 \mathrm{~cm}$ thick, which are similar to those that form the pool substrate. These basal crusts extend downstream $c a 10 \mathrm{~m}$ from the vent and rest on deltaic silts and sands. Dense clusters of small $(5 \mathrm{~mm}$ long) spicules, composed of convex (coniform) laminae of opaline silica or interlaminated silica and calcite, lie upon the calcite substrate where water flows over the top of rimstone dams in the channel. Strong steam-charged hydrothermal activity at some time between 2001 and 2005 eroded the proximal outflow channel, exposing older travertine crusts, several decimetres thick, which had been buried by deltaic sediments for more than 30 years (Fig. 7D and E). Some of those crusts were brecciated and overturned, now forming sub-vertical slabs embedded in the siliciclastic channel sediments.

\section{KL5f (inactive spring)}

The travertine at KL5f (Fig. 8) is mainly a fossil pool-rim dam. An ebullient pool spring (KL5), $c a$ $4 \mathrm{~m}$ in diameter with a temperature of $97^{\circ} \mathrm{C}$, lies $2 \mathrm{~m}$ north of the dam (Fig. 3B) but has no visible carbonate deposits. When forming, the pool-rim dam enclosed a hot pool with a diameter of $9.5 \mathrm{~m}$, but the dam is now broken in several places (Fig. 8A and B). The travertine dam, which is 0.5 to $1.5 \mathrm{~m}$ wide and up to $c a 1 \mathrm{~m}$ high, has a convex outer margin that slopes downwards from $45^{\circ}$ to $85^{\circ}$, becoming almost vertical near the ground surface. The inner (pool) margin has a terraced profile with ledges that record carbonate precipitation around the periphery of the pool at times when spring water level remained consistently below the height of the dam (Fig. 8C). Vertical, nearly circular tubes, 15 to $30 \mathrm{~cm}$ in diameter, in the dam wall might have been minor vents, although they lack pore-lining cements (Fig. 8D).

The pool floor consists of loose sandy sediments through which buried travertine deposits project above the land surface. Pits dug up to $80 \mathrm{~cm}$ below the pool floor showed that travertine does not form a continuous shallow base to the pool. A mound ca $70 \mathrm{~cm}$ high near the pool centre (Fig. 8A) may be near the site of a former vent. Most of the other pool-floor carbonates consist of ridges $<30 \mathrm{~cm}$ high, some of which are small rimstone dams that formed when the pool water level was much lower than the height of the rim. When they were forming, water would have flowed through openings or fractures in the dam wall (Fig. 8B).

Fractured surfaces show that the travertine is composed mainly of coarse $(5$ to $20 \mathrm{~cm}$ ) fans of dendritic calcite crystals and very porous platy calcite (Fig. 8E). The 'stems' of the dendrites that form the pool-rim dam and interior mounds have upward, downward and oblique orientations. Most dendrites forming the pool-rim dam are oriented vertically, forming beds 1 to $5 \mathrm{~cm}$ thick that lie parallel to the external surface of the dam. Weathered grey and pale-brown lacustrine stromatolites encrust much of the dam surface and the interior pool mounds and terraces (Fig. 8E and F).

The breaks in the dam wall (Fig. 8A) might have resulted from earthquakes, explosive hydrothermal eruptions or subsidence. The fracture walls are coated with grey stromatolites, showing that formation of the dam and its later fracturing pre-date the lacustrine carbonate encrustation during the mid-Holocene.

\section{Other springs with travertine}

Before 2007, a small jet of hot $\left(94^{\circ} \mathrm{C}\right)$ water flowed ca $40 \mathrm{~cm}$ above a single vent at the top of spring KL14a, a small (0.5 m high by $2 \mathrm{~m}$ diameter), subcircular travertine mound (Fig. 9A). The vent was vandalized after 2007, producing two vents, but in 2010 or 2011 further vandalism produced a single vent with sub-horizontal discharge. Outlying blocks up to $3 \mathrm{~m}$ from the vent confirm that the vent mound is the remnant of a former, more extensive travertine deposit. The remaining travertine is composed mainly of large calcite dendrites, each up to $15 \mathrm{~cm}$ long (Fig. 9B). Thin $(0.5 \mathrm{~cm})$, grey, lacustrine, stromatolitic calcite crusts disconformably overlie the eroded spring 

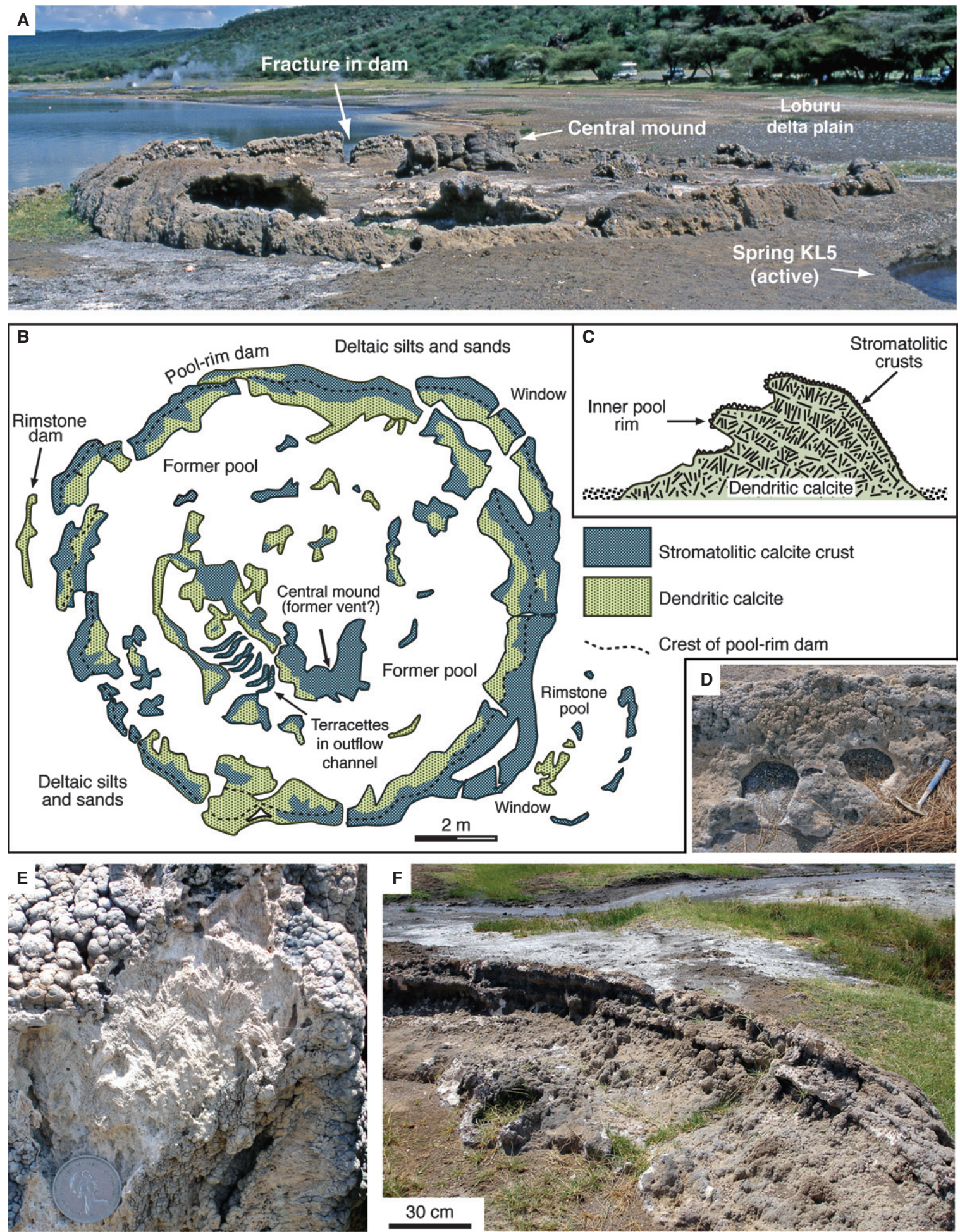

Fig. 8. Spring KL5f, Loburu. (A) Pool-rim dam and central mound (arrow), looking south. Margin of active spring KL5 is visible at the bottom right. (B) Plan of travertine deposit in July 1977. (C) Schematic cross-section through pool-rim dam wall. (D) Sub-circular mouldic structures of unknown origin (vents or tree trunk moulds?) in pool-rim dam. Hammer for scale (30 cm long). (E) Large, vertically oriented calcite-dendrites that form the pool-rim dam. Thin stromatolitic crust lies disconformably upon the dendrites. Coin diameter: $25 \mathrm{~mm}$. (F) Inner wall of pool-rim dam (ca $80 \mathrm{~cm}$ high) showing disconformable stromatolitic encrustation of older travertine. Scale bar applies only to base of photograph. 
dendrites (Fig. 9C). Dark-brown spicules, each 2 to $5 \mathrm{~mm}$ long and composed of calcite alone or combinations of variably interlaminated opaline silica, calcite and Mg-silicates, locally encrust the travertine mound in sites of recently falling spray. Microbial mats up to $2 \mathrm{~cm}$ thick cover moist parts of the mound where the temperature is $<70^{\circ} \mathrm{C}$, but are unmineralized except for local surficial silica crusts (Fig. 9C). Near the mound apex, four small ( $<10 \mathrm{~cm}$ high) open calcite chimneys were present in 1977 (Fig. 9D), one of which was then sampled and analysed chemically. Visitors have since destroyed all the chimneys.

Spring KL10 (Fig. 9E and F), an isolated boiling spring with high discharge located on a fault line at the northern margin of the southern delta lobe (Fig. 2), has a diameter of $c a 10 \mathrm{~m}$, but is only $c a$ $1 \mathrm{~m}$ deep. Brown crusts of calcite and $\mathrm{Mg}$ silicates, 1 to $5 \mathrm{~mm}$ thick, cover central parts of the pool floor and its outlet channel. Eroded patches of coarsely crystalline, banded travertine that lie 2 to $8 \mathrm{~m}$ north-west and east of the spring pool (Fig. 9E) are remnants of a pool-rim dam that formerly contained a larger (15 to $20 \mathrm{~m}$ diameter) spring pool. That travertine, although formed mainly of dendritic calcite, contains lenses of pink or white aragonite (confirmed by XRD) a few centimetres thick and up to $2 \mathrm{~m}$ wide.

Spring KL9, a small pool spring with several subsidiary vents, lacks evidence for recent carbonate precipitation, but pale-brown, low-amplitude hemispheroidal calcite crusts coat gravel in the proximal outflow channel. Angular blocks of eroded travertine, up to $60 \mathrm{~cm}$ across, lie near the vents; loose travertine gravel is present on the discharge apron (Fig. 9G).

Erosion in 2001 exhumed pale-brown, mammillary calcite crusts up to $c a 3 \mathrm{~cm}$ thick on the gravelly floor of the proximal outflow channel of spring KL3 (Fig. 2), a boiling spring. This spring showed no evidence of travertine when first visited in 1976.

An unusually low lake level during summer 2006 revealed three small offshore travertine mounds (KLO-1, KLO-2 and KLO-3) that had been submerged for most of the previous 30 years (Fig. 2). These mounds are composed of beds and lenses of coarse ( $>2 \mathrm{~cm}$ long) dendritic calcite crystals similar to those present in the onshore travertines. The largest mound, KLO-2 (Fig. 9H), has centimetre-scale terraces on its surface and pockets of pisoids $(<1 \mathrm{~cm}$ diameter $)$ in former proximal pools near its base (Fig. 9I). When exposed in 2006, hot waters actively flowed from mounds KLO-1 (T: $\left.76 \cdot 3^{\circ} \mathrm{C}\right)$ and $\mathrm{KLO}-2\left(\mathrm{~T}: 81 \cdot 5^{\circ} \mathrm{C}\right)$.
Travertine at spring KLO-3, which had lower discharge and a lower temperature $\left(\mathrm{T}: 47 \cdot 9^{\circ} \mathrm{C}\right.$ ) than the adjacent mounds, is limited to a thin $(<5 \mathrm{~mm})$ discontinuous crust on the rim of a small (ca $1 \mathrm{~m}$ diameter) pool. Another mound of dendritic calcite travertine (KLO-4: Fig. 2), with three small $(<5 \mathrm{~cm}$ diameter) springs at its base, was exposed briefly during summer 2006 .

Most pool and seepage springs in the southern Loburu group (Fig. 2A) discharge quietly. Weakly indurated mud-substrates around some springs periodically have brown ephemeral coatings of calcite only ca $1 \mathrm{~mm}$ thick, but neither travertine nor silica sinter is present on the delta surface. When active, the southern Loburu geysers erupt directly from mud.

\section{Mineralogy}

The Loburu travertine is composed mainly of calcite. Minor amounts of aragonite were detected by XRD in samples from KL5f and KL10. Accessory minerals include: fluorite, which locally replaces $\mathrm{CaCO}_{3}$ and forms euhedral cements; authigenic Mg-silicates (poorly crystalline smectite and sepiolitic clays?) that form thin (1 to $4 \mu \mathrm{m}$ ) coatings upon some calcite crystal surfaces; and poorly crystalline Fe and Mn oxyhydroxides, which also coat calcite surfaces. Fluorite locally forms thin $(<2 \mathrm{~mm})$ bluish grey coatings on travertine at sites near the vents (for example, KL6a). Opaline silica (opal-A) is common in spicules, in which it is locally interlaminated with calcite. Euhedral acicular and bladed trona, thermonatrite, nahcolite and halite crystals, which line pore walls in some travertines, probably precipitate by evaporation of recent spring fluids. Detrital particles form lenses in some travertines and variably occlude porosity, locally producing geopetal fills. Those particles are mainly lithic fragments (phonolite), K-feldspar grains (sanidine and anorthoclase), corroded volcanic-glass shards, and rare bone fragments, some of which are silicified. Calcite, opal-A, fluorite, pyrite and analcime are also present in fossil root casts in marshy areas that received hotspring effluent (Owen et al., 2008).

\section{Fabrics and diagenesis}

The Loburu travertines resemble other thermalspring carbonates in morphology. These carbonates differ significantly from those described from most other well-known travertine sites (for example, in Italy and Turkey), however, because 
Fig. 9. Travertine at other Loburu springs. (A) Spring KL14a, a small spouting spring, in July 2001. The vent mound ' $\mathrm{V}$ ' and outlying travertine blocks in foreground are composed mainly of dendritic calcite, partly coated by lacustrine stromatolite crusts. Modern opaline silica crusts 'Si' are present around the spring margins. (B) Large, fossil calcite dendrites from mound of spring KL14a. Lens cap diameter: $52 \mathrm{~mm}$. (C) Travertine from the vent mound of spring KL14a. Fossil calcite dendrites ' $D$ ' are encrusted by lacustrine stromatolites ' $S$ ' that, in turn, are covered by unmineralized cyanobacterial mats 'M'. Opaline silica 'Si' thinly coats some surfaces. (D) Small, fossil calcite chimneys from vent mound of spring KL14a. Photograph taken in July 1977 before the chimneys were destroyed; their vent location and stable isotope composition (Table 2) preclude an alternative interpretation of these features as encrusted plants. (E) Dark stromatolitic crust overlying coarse calcite and aragonite crystal beds at spring KL10. (F) Boiling spring KL10 showing vent. Thin, pale-brown, travertine crusts cover the spring floor. Remnants of a pool-rim dam (arrow) around the pool margins are evidence of an older larger spring-pool. (G) Pale-brown calcite crusts $(<2 \mathrm{~cm}$ thick) in outflow channel of spring KL9. (H) Vent mound of spring KLO-2, which was briefly exposed when the lake level fell almost a metre during 2005 and 2006. A small spring 'S' was then flowing at the north end of the mound. (I) Pockets of stratified, ovate and sub-spherical calcite pisoids from former pool below the vent of spring KLO-2 ['P' in panel (H)]. Scale bars apply only to the bottom (proximal) part of each photograph.

they are dominated by dendritic, platy and other high-disequilibrium calcite crystal fabrics, which typically account for $>80 \%$ of the rock mass.

\section{Dendritic fabrics}

The travertines forming the pool-rim dam of KL5f, the spring mounds KL8, KL14a and KLO-1, and parts of the pool margins and mound at KL6 contain many beds of coarsely crystalline calcite dendrites (Jones \& Renaut, 1995). 'Feather dendrites' have stems $0 \cdot 2$ to $0 \cdot 3 \mathrm{~mm}$ in diameter with curved side branches that show multiple generations of crystal splitting (Fig. 10A and B). 'Scandulitic dendrites' consist of en echelon calcite plates, $0 \cdot 3$ to $0 \cdot 4 \mathrm{~mm}$ across, with a central stem $c a \cdot 0 \cdot 1 \mathrm{~mm}$ in diameter (Fig. 10C). Individual dendrite bushes are typically 0.5 to $5 \mathrm{~cm}$ long, but curved featherdendrite stems up to $15 \mathrm{~cm}$ long are present at KL14a and KL5f. Scandulitic dendrites form beds 1 to $5 \mathrm{~cm}$ thick with stems sub-parallel to each other. These individual dendrites are typically rooted to the substrate at sites where shallow ( $<10 \mathrm{~cm}$ deep) water flowed across the surface. Feather dendrites, in contrast, are more common where crystals grew in open water, including poolmargin overhangs, because some of them grew downwards. Dendrites are the framework of many rimstone pools and dams (Fig. 4B).

\section{Platy fabrics}

Platy calcite crystals, each of which has its $c$-axis parallel to its shortest length axis, form composite crystals composed of many hexagonal sub-crystals. Several types of platy calcite are recognized based on the size, arrangement and abundance of the individual plates (Fig. 10D and E). 'Lattice crystals' are boxlike networks of thin platy subcrystals arranged in bundles of elongate crystals (Jones \& Renaut, 1998, fig. 4). 'Pseudodendrites' are aggregates of platy crystals that form complex branching structures (Jones \& Renaut, 1998, figs 7 and 10). Some aggregates of platy crystals forming lattices are arranged in tightly packed columnar bundles that resemble 'palisade' calcite (Fig. 10F); other platy crystals form open networks with $>50 \%$ porosity (Fig. 10D).

Bundles of platy crystals form beds 1 to $3 \mathrm{~cm}$ thick on the floor of pools and around their margins, line the floor of proximal outflow channels (KL6 and KL8) and encrust loose debris, forming coated grains. Platy crystals are locally interbedded with, or form pockets in, calcite dendrites, suggesting that both types form under similar physicochemical conditions.

\section{Columns and spicules}

Small (1 to $5 \mathrm{~mm}$ tall) columns or 'spicules' of calcite and opaline silica that form on the travertine surface or are encased in later calcite are a distinctive microfacies (Fig. 11A to C). These narrow $(<4 \mathrm{~mm}$ diameter) columns are composed internally of laminae 10 to $50 \mu \mathrm{m}$ thick and, based on energy-dispersive X-ray spectroscopy (EDS) analyses on the SEM, are variably composed of calcite, irregularly interlaminated calcite and opal-A, opal-A alone, or a mixture of calcite and Mg-silicate. Some dark laminae contain wispy organic matter, whereas other dark laminae are poorly crystalline Mg-rich clays or calcite crystals thinly coated with Mg-rich clay. These spicular columns grow in two settings: (i) very shallow pool floors near spring vents where modern waters exceed $80^{\circ} \mathrm{C}$; and, more commonly, (ii) at the air-water interface of waters with $\mathrm{T}>80^{\circ} \mathrm{C}$, including the outward-facing edges of small rimstone dams, and in spray zones from spring jets. The SEM observations have shown that coccoid bacterial cells are preserved (replaced) 

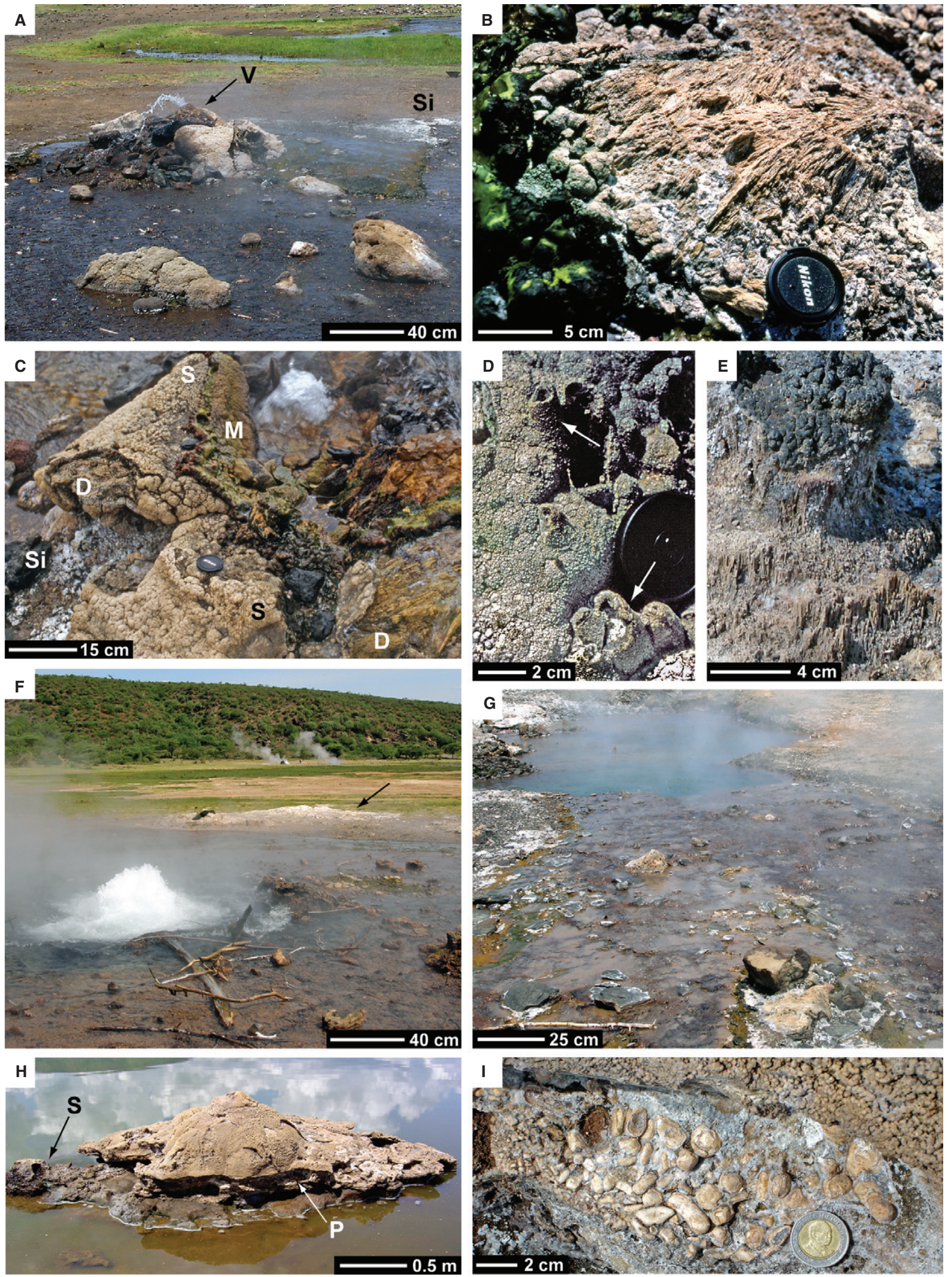

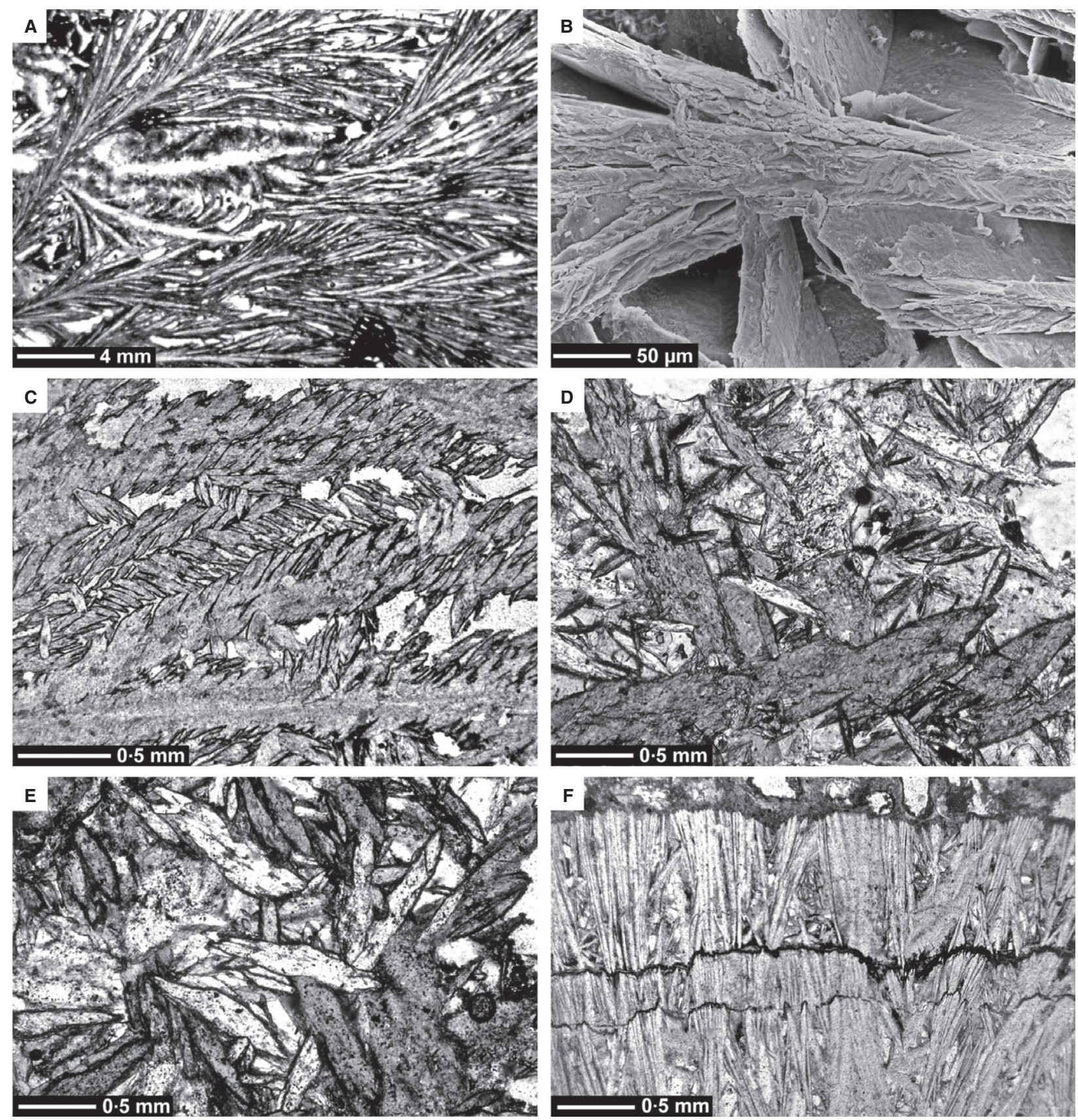

Fig. 10. Typical textures of Loburu travertine: 1: Dendritic and platy calcite. All plane-polarized-light photomicrographs except (B). (A) Calcite feather dendrites, spring KL8. (B) Crystal splitting in calcite dendrite, spring KL6. SEM photomicrograph. (C) Scandulitic dendrites, spring KL5f. (D) and (E) Platy calcite, spring KL6. (F) Lattice crystals, basal crust, spring KL8.

in some of the silica laminae of the spicules, but are poorly preserved or absent in calcite laminae.

\section{Microbial fabrics}

Some crystal beds ( 1 to $4 \mathrm{~cm}$ thick) and laminae $(<1 \mathrm{~cm})$ in the travertines are highlighted in thin section by thin dark-brown layers $(<5 \mathrm{~mm})$ that appear to be organic (Fig. 11D and E). As noted by Casanova $(1986,1994)$ and Casanova \& Renaut
(1987), organic laminae and clots of possible microbial origin are present in some travertines, and possible (brown) organic matter inclusions are seen rarely in calcite crystals. Extracellular polymeric substances (EPS), some silicified as opal-A, lie between adjacent calcite crystal faces in some dark laminae, implying the former presence of microbes. Generally, however, microbial remains are poorly preserved in these 
laminae when viewed by SEM, and the dendritic and platy crystals lack fossilized microbial cells and moulds, both on their surfaces and inside fractured crystals.

\section{Encrusting stromatolites}

The external surfaces of many travertines consist of pale-brownish grey to greyish brown stromatolitic crusts up to $1 \mathrm{~cm}$ thick that usually have a sharp contact with the underlying travertine (Fig. 8E). Most stromatolitic crusts consist of alternating light and dark laminae (50 to $400 \mu \mathrm{m}$ thick) with a laterally linked hemispheroidal pattern (Fig. 11F and G). The hemispheroids are small, each with a basal diameter of $<1 \mathrm{~cm}$. Individual laminae are usually well-defined, continuous across adjacent hemispheroids and composed of fine (2 to $10 \mu \mathrm{m}$ ) anhedral to subhedral calcite crystals (microsparite). Erect and prostrate microbial filaments, many resembling erect oscillatorian cyanobacteria, are preserved as isolated filaments in some laminae or form collapsed, dark-brown organic clumps in thin section (Fig. 11H). Similar calcite stromatolites encrust volcanic bedrock and other firm substrates around the shoreline (Renaut, 1982; Casanova, 1986, 1994; Vincens et al., 1986). Not all of the outermost mammillary crusts at Loburu are lacustrine: some are composed of dendritic and platy crystals that precipitated from spring water flowing across travertine surfaces, but they have a similar, centimetre-scale, hemispheroidal topography.

\section{Other fabrics}

Travertine breccias are common at Loburu (Fig. 11I). The carbonate clasts, millimetres to decimetres in size, were formed by weathering, littoral erosion, trampling by mammals (including tourists since $c a$ 1975), occasional hydrothermal explosions or collapse and subsidence.

The cortices of the small pisoids in the outflow channels of springs KL6 and KLO-2 are composed of concentric calcite laminae $(<1 \mathrm{~mm})$ surrounding nuclei of detrital calcite, feldspar or lithic grains. Laminae are 10 to $150 \mu \mathrm{m}$ thick; some are radially aligned columns of platy calcite, whereas others are formed of dense micritic calcite and microsparite.

\section{Early diagenesis}

The unusual carbonate fabrics at Loburu make it difficult to compare the degree of diagenetic alteration of the travertines with those found elsewhere. The preservation of fine platy and dendritic crystal textures and the high porosity in most of the travertines imply that little cementation occurred after precipitation, even if they were later submerged by lake water. Nonetheless, microsparite cements locally filled some pores between dendrites, platy crystals and spicules; some microsparite patches appear to have replaced dendrites. Some cements contain acicular inclusions that could have been relic platy calcite or aragonite crystals. Fluorite, some containing cubic fluid inclusions, is a cement in some Loburu travertines (KL6), where it fills porosity and replaces calcite or possibly aragonite.

\section{Stable isotope geochemistry}

Stable oxygen and carbon isotope analyses of the travertines and lacustrine stromatolites at Lake Bogoria were previously reported by Casanova (1986, 1987a), Casanova \& Renaut (1987) and Renaut \& Jones (1997). New analyses of 26 travertine samples and four lacustrine stromatolites from Loburu (Table 2) confirm the previous results. The $\delta^{13} \mathrm{C}_{\mathrm{PDB}}$ values for all the analysed travertines range from -1.83 to $0 \cdot 20 \%$ (mean: $-0.95 \%$ ), whereas the $\delta^{18} \mathrm{O}_{\mathrm{PDB}}$ varies from $-12 \cdot 66$ to $-8 \cdot 67 \%$ (mean: $-11 \cdot 27 \%$ ) (Fig. 12 ). No systematic variation in stable isotopic composition of the travertine was detected across Loburu delta. All analysed samples of lacustrine stromatolites that encrust the travertines and bedrock fall within the range of isotopic values previously reported by Casanova (1986, 1987a) (3.90 to $7 \cdot 79 \% \delta^{13} \mathrm{C}_{\mathrm{PDB}}$; mean: $6 \cdot 79 \% ; 2 \cdot 41$ to $8 \cdot 28 \%$ o $\delta^{18} \mathrm{O}_{\mathrm{PDB}}$; mean: $4 \cdot 95 \%$ ).

Casanova \& Renaut (1987) noted that the predicted palaeotemperatures for calcite precipitation in the travertine would be $c a 80^{\circ} \mathrm{C}$, using the mean oxygen isotopic composition of nine modern (1984) spring waters $\left(-1 \cdot 2 \% \delta^{18} \mathrm{O}_{\text {SMOW: }}\right.$ Pagé, $1987)$ and the equations of O'Neil \& Clayton (1964) and O'Neil (1968). That calcite, however, was probably not in isotopic equilibrium with the contemporary fluid phase (Chafetz \& Lawrence, 1994; Renaut \& Jones, 1997) because the crystal morphologies imply growth under conditions of high disequilibrium (i.e. rapid $\mathrm{CO}_{2}$ degassing). Although the oxygen isotopic compositions of the spring and lake waters at Lake Bogoria have probably changed over time, the predicted palaeotemperatures of calcite precipitation nonetheless fall within the temperature range of the modern thermogene spring waters. The stable isotope data do not prove that the Loburu travertines precipitated at temperatures close to local boiling point, but the new results support the petrographic 
Fig. 11. Typical textures of Loburu travertine: 2: Other textures. All plane-polarized-light photomicrographs except (C). (A) Spicule from mound of spring KL14a showing convex laminae of calcite, Mg-silicate, opal-A and organic matter, encased in later calcite microsparite. (B) Adjacent spicules viewed from above along their vertical axes. Radiating platy calcite crystals that grew normally $\left(\mathrm{ca} 90^{\circ}\right)$ from the external spicule surfaces after submergence in spring outflow waters produced the 'sunflower' appearance. (C) Binocular microscope image of crust from the floor of spring KL8 showing subaqueous calcite dendrites overlain by mainly subaerial, calcite-silica spicules. (D) and (E) Basal crusts from spring KL8a (D) and KL6 (E) showing sub-vertical platy calcite crystals and thinner, darker laminae containing calcite, Mg-silicates and lenses of organic matter. (F) Stromatolitic crust from spring KL6. (G) Travertine crust from spring KL6. Relict platy calcite 'P' is disconformably overlain by lacustrine stromatolites 'S' that, in turn, are overlain by a later, subaerial travertine crust ' $\mathrm{T}$ '. (H) Stromatolite from vent mound of spring KL5f showing erect filamentous cyanobacteria and clots of pale-brown organic matter (EPS and lysed cells?) in microsparite laminae. (I) Travertine breccia, spring KL6. Fractured columnar crystals and spicules are embedded in calcite microsparite cement.

evidence, which implies that the calcite precipitated abiotically at temperatures of $>80^{\circ} \mathrm{C}$, which exceeds the maximum tolerance temperature of thermophilic cyanobacteria (Brock, 1978).

Vertical changes in the stable isotopic composition were examined in two large samples, one from the pool-rim dam of KL5 $\mathrm{f}$ and one from the vent mound of KL14a (Fig. 12B). The KL5f sample shows an abrupt increase in both $\delta^{13} \mathrm{C}$ and $\delta^{18} \mathrm{O}$ enrichment at the upper part of the sample, which is attributed to a change from hydrothermal to lacustrine carbonate precipitation. In contrast, a transition is recorded in the vent sample (chimney) from KL14a (Fig. 12B). That sample plots on an inferred mixing line between the travertines and lacustrine stromatolites (Fig. 12A). A few travertine analyses plot on a possible linear trend between the cluster of travertines precipitated from deeper, higherenthalpy thermal fluids and those precipitated from low-enthalpy $\left(\mathrm{T}<50^{\circ} \mathrm{C}\right)$ 'warm' springs.

\section{DISCUSSION}

\section{Formation of the Loburu travertines}

The Loburu travertines are unusual, not only for their high temperature of precipitation and unusual crystal textures, but also because they are largely relict deposits that are preserved around springs with fluids that today precipitate minor amounts of silica and authigenic clays, but little $\mathrm{CaCO}_{3}$. This observation suggests that the physicochemical characteristics of the spring waters might have changed through time in response to environmental factors, changes in ground water circulation and recharge, or other causes.

The dominant dendritic and platy fabrics imply precipitation under conditions of high disequilibrium during calcite crystal growth. Dendritic and platy crystals are commonly associated with rapid crystallization, but other factors, including organic and chemical impurities, can impede more typical, polyhedral crystal growth. Jones \& Renaut $(1995,1998)$ suggested that rapid exsolution of $\mathrm{CO}_{2}$ upon shallow boiling and during surface discharge might induce high levels of supersaturation that favour dendritic calcite crystallization at several Kenyan hot springs, and that a high $\mathrm{CO}_{3}{ }^{2-} / \mathrm{Ca}^{2+}$ ratio and low total $\mathrm{Ca}^{2+}$ concentration in those fluids promote the formation of platy calcite.

Calcite-encrusted bottle caps (Fig. 6C) and other encrusted artefacts confirm recent carbonate precipitation. Those springs where recent calcite precipitation has been inferred have a high gas flux, very high vent temperatures $\left(>97^{\circ} \mathrm{C}\right)$, and (or) high fluid discharge. Springs KL1, KL6, KL8, KL9 and KL10 are always boiling and highly ebullient. Rapid exsolution of $\mathrm{CO}_{2}$ also contributes to this high effervescence, including episodic geyser activity at southern Loburu (Renaut et al., 2008). Most, but not all, springs without recent calcite have lower discharge and are less ebullient; this does not prove that a high gas flow, rapid $\mathrm{CO}_{2}$ exsolution at or near the surface, and high fluid discharge are needed for calcite to precipitate at Loburu, but this relation is apparent. The high dissolved-gas concentration, principally of $\mathrm{CO}_{2}$, enhances rapid outgassing and effervescence upon boiling and pressure reduction, and the high fluid discharge continuously supplies $\mathrm{Ca}^{2+}$, even though its total concentration remains very low. Rapid degassing of $\mathrm{CO}_{2}$ is expected given the high calculated values of $\mathrm{PCO}_{2}$. The highest values were recorded at springs KL6 and KL14a, both of which have travertine at their vents.

Microbial mats and biofilms are present at all active Loburu springs, so microbial mediation of calcite precipitation should be considered. All modern mats are unmineralized except for minor 

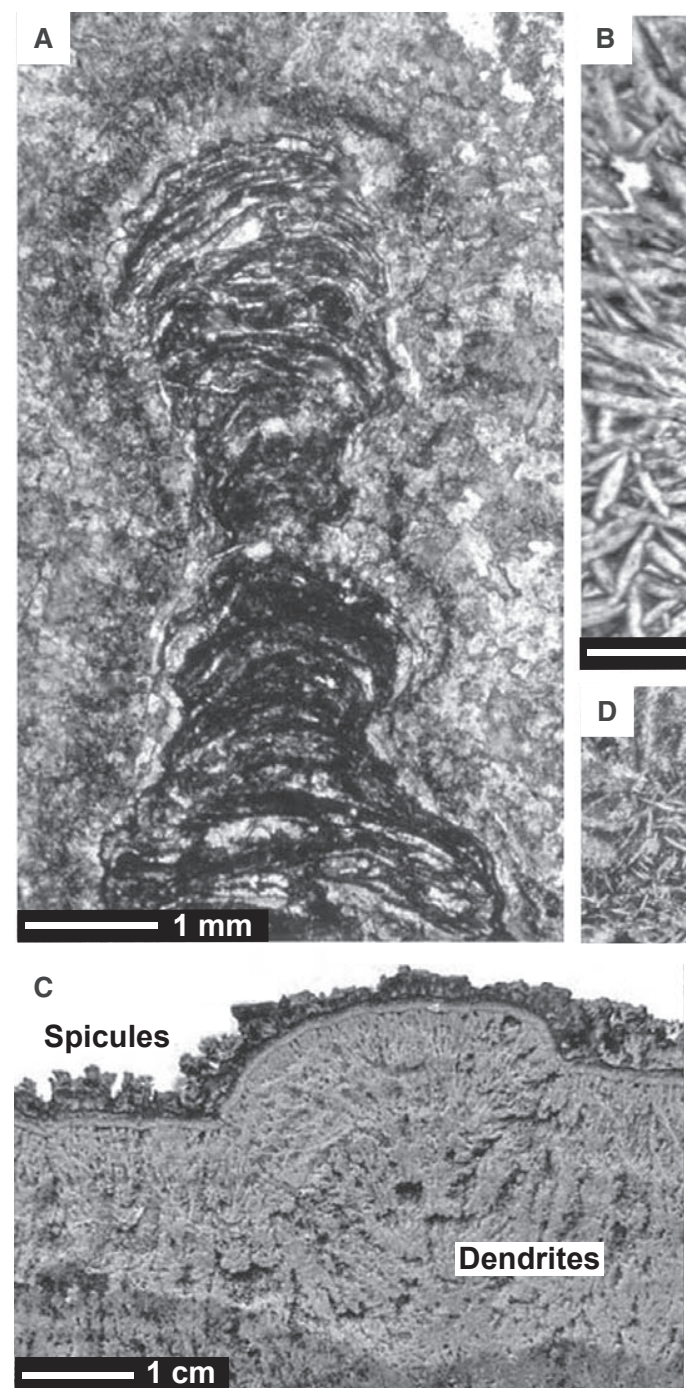

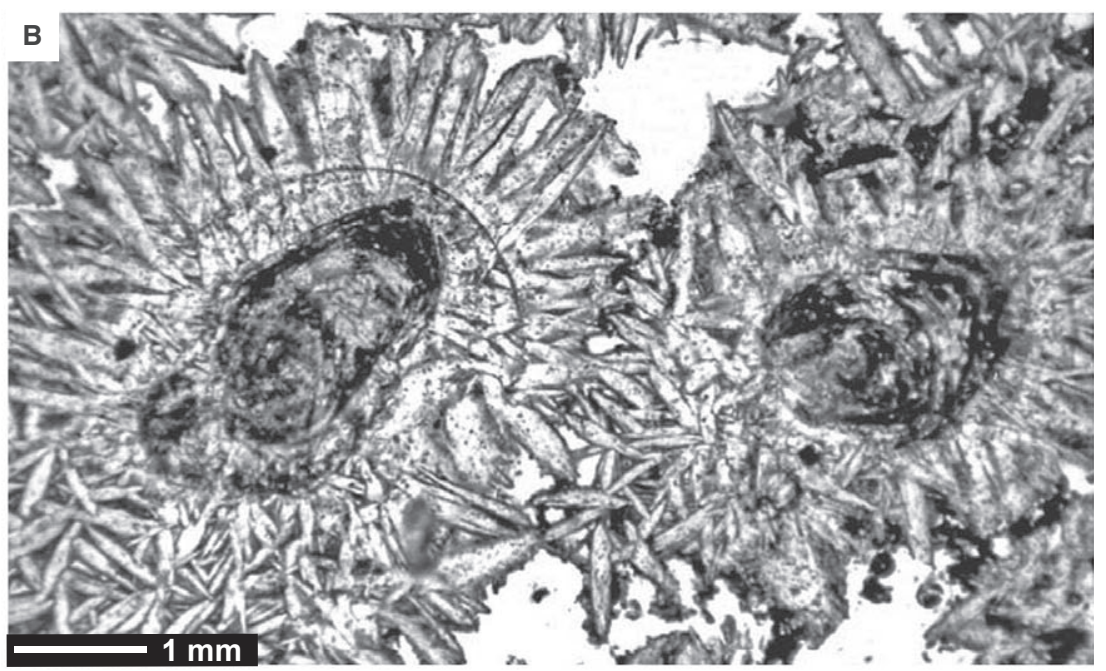

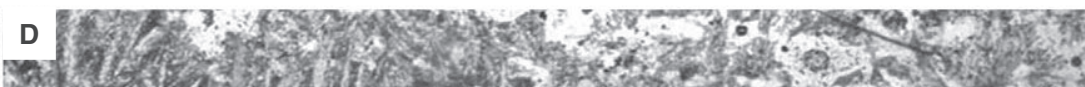

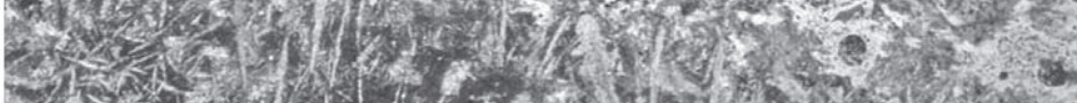

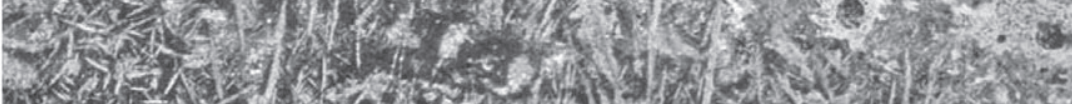
4.

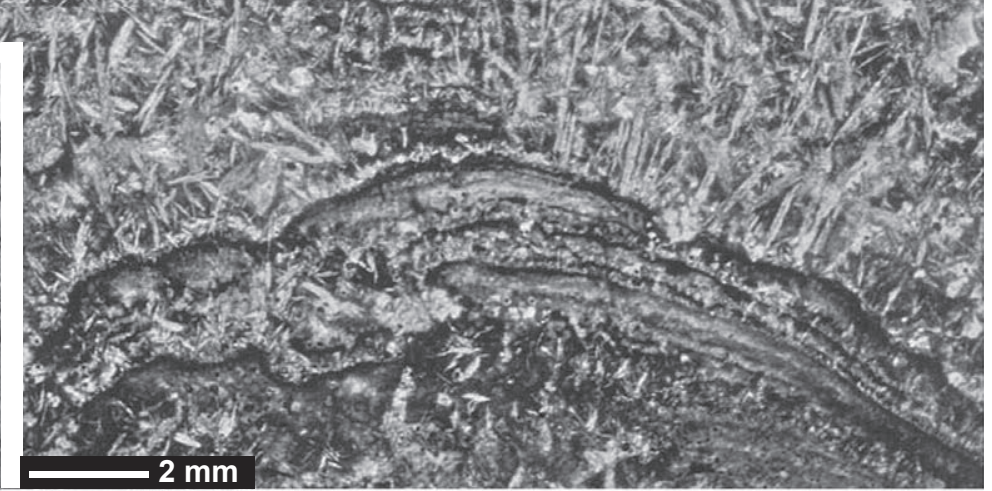

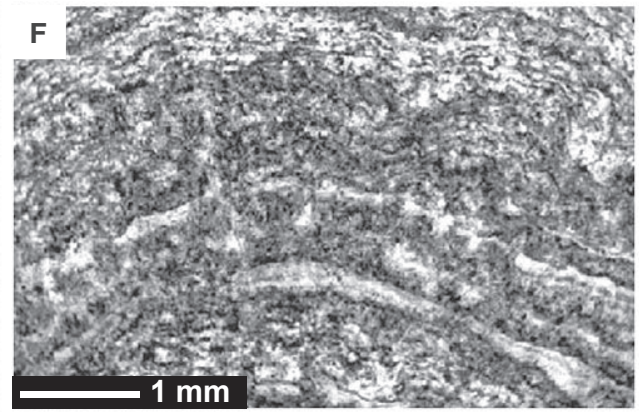

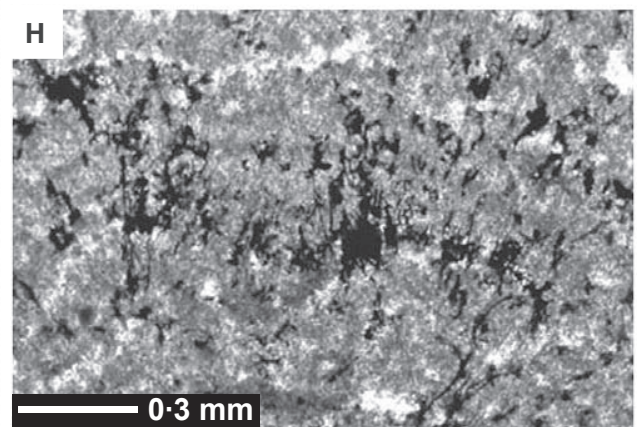

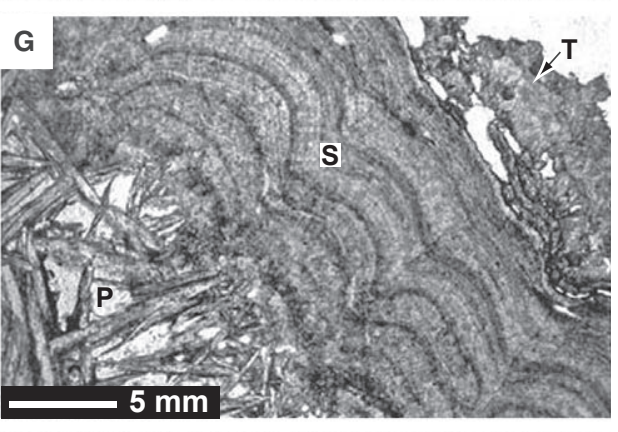

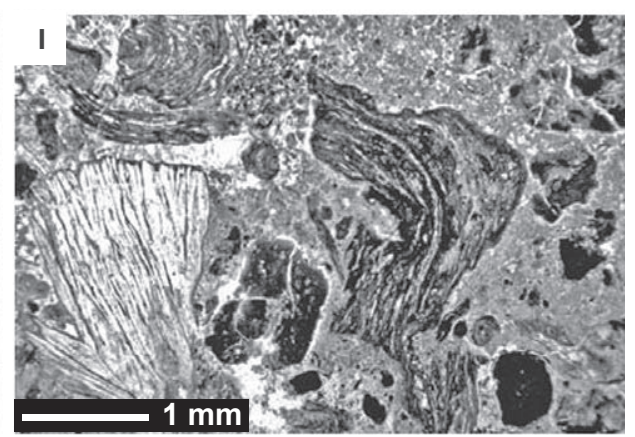


Table 2. Stable carbon and oxygen isotope analyses of Loburu travertines and palaeolake-margin stromatolitic crusts (all analysed samples were calcite).

\begin{tabular}{|c|c|c|c|}
\hline $\begin{array}{l}\text { Spring and sample } \\
\text { number }\end{array}$ & $\delta^{18} \mathrm{O}(\%$ ооРB $)$ & $\delta^{13} \mathrm{C}(\%$ оРDB $)$ & Context \\
\hline \multicolumn{4}{|l|}{ Travertines } \\
\hline KL5-f & $-11 \cdot 68$ & $-1 \cdot 07$ & Old mound \\
\hline KL5-g & $-12 \cdot 03$ & $-1 \cdot 77$ & Outlying rimstone dam \\
\hline KL5f-a & $-11 \cdot 88$ & $-0 \cdot 81$ & Base of rim $\left(-58 \mathrm{~cm}^{*}\right)$ \\
\hline KL5f-b & $-10 \cdot 98$ & $-0 \cdot 81$ & Dendrites $\left(-38 \mathrm{~cm}^{*}\right)$ \\
\hline KL5f-c & $-12 \cdot 06$ & -0.83 & Dendrites $\left(-21 \mathrm{~cm}^{*}\right)$ \\
\hline KL5f-d & $-11 \cdot 88$ & $-0 \cdot 96$ & Top of rim $\left(-3 \mathrm{~cm}^{*}\right)$ \\
\hline KL6-a & $-11 \cdot 91$ & $-0 \cdot 88$ & Pool rim dendrites \\
\hline KL6-b & $-10 \cdot 23$ & $-1 \cdot 22$ & Terrace dendrites \\
\hline KL6-C & $-12 \cdot 24$ & $-0 \cdot 90$ & Pisoid \\
\hline KL6-d & $-11 \cdot 66$ & -0.97 & Terrace near vent \\
\hline KL6-e & $-12 \cdot 49$ & $-1 \cdot 31$ & Terrace near vent \\
\hline KL6-g & $-9 \cdot 08$ & $-0 \cdot 06$ & Outflow channel \\
\hline KL8-a & $-9 \cdot 88$ & $-0 \cdot 84$ & Old mound \\
\hline KL8-b & $-10 \cdot 85$ & $-0 \cdot 76$ & Old mound, near vent \\
\hline KL8-C & $-12 \cdot 04$ & $-0 \cdot 84$ & Pool-floor crust \\
\hline KL8-d & $-11 \cdot 84$ & $-1 \cdot 52$ & South margin of pool \\
\hline KL9-a & $-8 \cdot 67$ & $-1 \cdot 28$ & Basal pool crust \\
\hline KL10-a & $-12 \cdot 66$ & $-1 \cdot 83$ & Relict travertine near pool \\
\hline KL10-b & $-12 \cdot 00$ & $-0 \cdot 41$ & Relict travertine block \\
\hline KL14a-a & $-12 \cdot 07$ & $-1 \cdot 21$ & Base of mound $\left(-39 \mathrm{~cm}^{*}\right)$ \\
\hline KL14a-b & $-12 \cdot 28$ & $-1 \cdot 08$ & Mound $\left(-32 \mathrm{~cm}^{*}\right)$ \\
\hline KL14a-c & $-10 \cdot 72$ & $-0 \cdot 87$ & Mound $\left(-22 \mathrm{~cm}^{*}\right)$ \\
\hline KL14a-d & $-9 \cdot 66$ & $-1 \cdot 07$ & Mound $\left(-11 \mathrm{~cm}^{*}\right)$ \\
\hline KL14a-e & $-6 \cdot 15$ & $2 \cdot 88$ & Chimney, mound top ( 0 to $-1 \mathrm{~cm}^{*}$ ) \\
\hline KL14a-f & $-8 \cdot 87$ & $-0 \cdot 88$ & Block north of vent \\
\hline KL14a-g & $-9 \cdot 84$ & $0 \cdot 20$ & Isolated block near vent \\
\hline \multicolumn{4}{|l|}{ Stromatolites } \\
\hline KL5f-e & $4 \cdot 77$ & $6 \cdot 94$ & KL5f rim, surficial crust, 0 to $-1 \mathrm{~cm}^{*}$ \\
\hline LobNc-1 & $4 \cdot 82$ & $7 \cdot 05$ & North delta, crust on boulder, $+0 \cdot 5 \mathrm{~m}^{* *}$ \\
\hline LobSc-1 & $4 \cdot 88$ & $7 \cdot 11$ & South delta, crust on boulder, $+0 \cdot 8 \mathrm{~m}^{* *}$ \\
\hline LobSc-2 & $4 \cdot 55$ & $6 \cdot 66$ & South delta, crust on bedrock, $+1 \cdot 8 \mathrm{~m}^{* *}$ \\
\hline
\end{tabular}

*Depth of sample below top of feature (i.e. rimstone dam of KL5a or the vent mound of KL14a).

**Elevation of sample above lake level when collected during November 1991.

silicification where the associated spring fluids have cooled and undergone capillary evaporation (Renaut et al., 1998). Most of the calcite does not contain preserved organic remains. Casanova (1986, 1994), Casanova \& Renaut (1987) and Jones \& Renaut (1995) illustrated very thin, platy calcite surfaces coated by possible bacterial cells and reticulate networks $<4 \mu \mathrm{m}$ thick that resemble desiccated microbial exopolymers. The EDS analyses of those networks consistently reveal dominant peaks for $\mathrm{Mg}$ and $\mathrm{Si}$, with minor peaks for $\mathrm{Al}, \mathrm{Na}, \mathrm{Fe}$ and $\mathrm{Ca}$ in some samples. This element association implies that these coatings are either poorly crystalline Mg-silicates, similar to smectite, sepiolite and saponite, or microbial biofilms that have preferentially taken up those elements by sorption processes (Geptner et al., 2002). Un- like many travertine springs, the inferred high temperatures of calcite precipitation $\left(>80^{\circ} \mathrm{C}\right)$ would probably have excluded all microbes except hyperthermophiles. Mg-silicates with a similar reticulate morphology coat mineral surfaces in alkaline hot springs in New Zealand (Jones et al., 2003) and form in the boiling zone of geothermal wells (McLin et al., 2012) and in geothermal power plants (Kristmannsdóttir et al., 1989). Lenses of rippled, purple-grey Mg-silicates up to $7 \mathrm{~mm}$ thick coat substrates in the proximal ( $<10 \mathrm{~m}$ from the vent) outflow waters of geyser C1 at northern Chemurkeu in water with temperatures $>90^{\circ} \mathrm{C}$.

Although some travertine fabrics are potentially of biotic origin (i.e. with crystal growth seeded by living or recently dead bacteria or archaea), the 


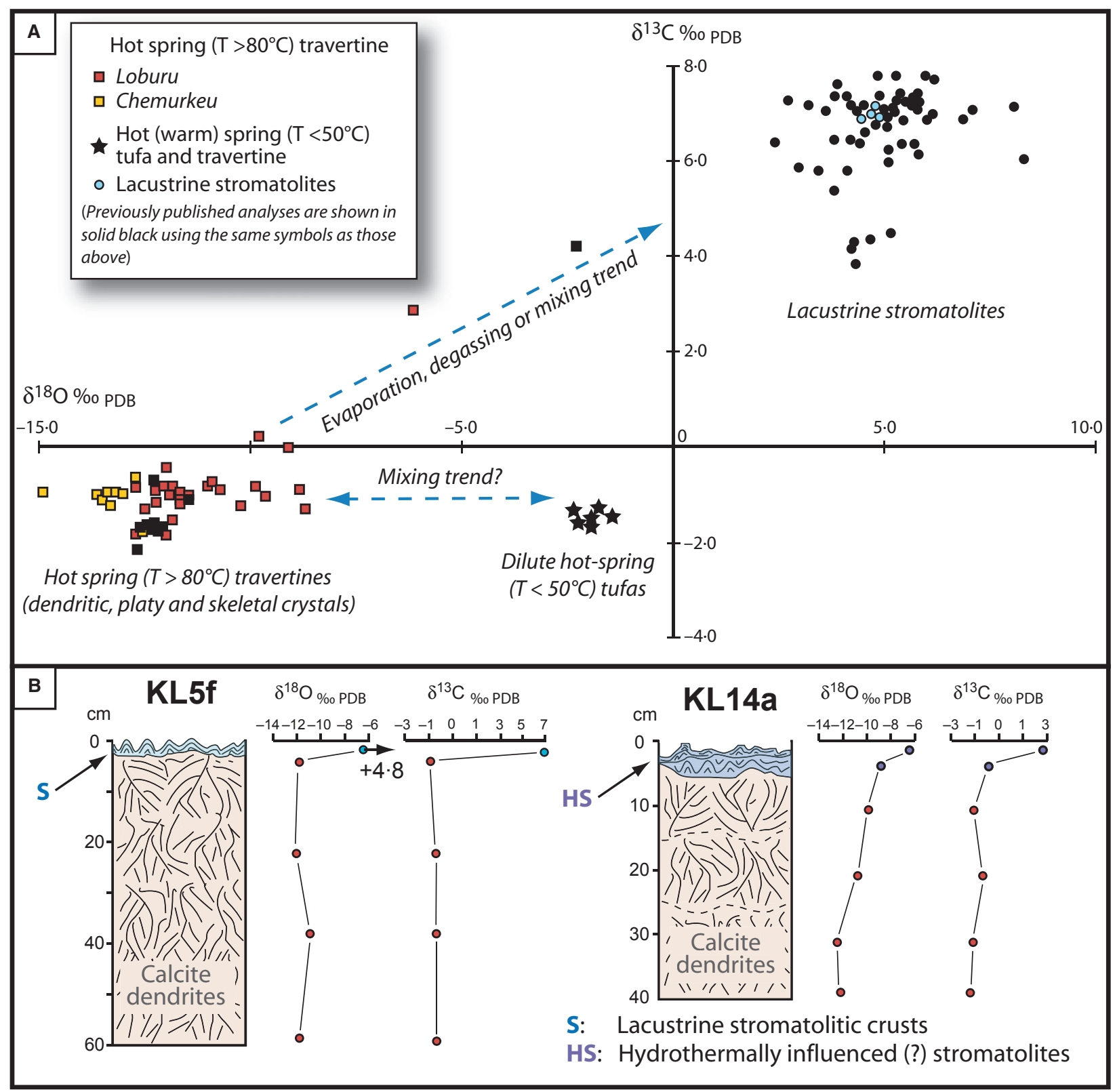

Fig. 12. Stable $\mathrm{O}$ and $\mathrm{C}$ isotope analyses of Loburu travertines and lacustrine stromatolites from Lake Bogoria. (A) Plot of $\delta^{13} \mathrm{C} \%$ орDB versus $\delta^{18} \mathrm{O} \%$ оров. This plot combines the data originally presented by Casanova (1987a, fig. 86) and 30 original analyses (this study). (B) Vertical variations in $\mathrm{O}$ and $\mathrm{C}$ isotopic composition in travertines from the pool-rim dam of spring KL5f (Fig. 8F) and the vent mound of spring KL14a (Fig. 9A, C and D) (original analyses).

predominant dendritic and platy crystals are most easily explained by abiotic crystallization. Separating abiotic from biotic calcite crystal nucleation in such high-temperature environments is difficult (Chafetz \& Guidry, 1999; Fouke, 2011), but 'bacterial shrubs', as originally described by Chafetz \& Folk (1984), are absent, possibly because the discharged fluids are not sulphurous and lack those bacteria or archaea that may promote bacterial shrub growth. Branching and platy crystal morphologies similar to those at
Loburu grow abiotically as calcite and several other minerals in other natural (Simmons \& Christenson, 1994) and sterile industrial settings (Galenko \& Zhuravlev, 1994).

Dark-brown laminae and lenses containing patchy organic residues separate beds of crystalline calcite in some travertines (Fig. 11D). Many organic layers, however, probably record brief intervals of substrate colonization by microbes when calcite was not precipitating at that site, rather than representing benthic mats or biofilms 
Fig. 13. Other carbonates at and near Lake Bogoria. (A) Alternating calcite ' $C$ ' and aragonite 'A' travertine filling fractures and joints in phonolite ' $\mathrm{P}$ ' bedrock, shoreline of northern Chemurkeu. This banded travertine, which formed phreatically from boiling fluids in the shallow $(<5 \mathrm{~m}$ ?) subsurface, was later eroded, then encrusted by lacustrine calcite stromatolites ' $\mathrm{S}$ ' that coated both the eroded phreatic travertine and host volcanic bedrock. (B) Large mound, southern Chemurkeu. The mound is an erosional relic of more extensive subaerial travertine deposits that were $c a 4 \mathrm{~m}$ higher than the fracture-fills shown in Fig. 13A. When the photograph was taken, the mound was $c a$ $70 \mathrm{~m}$ from the lake shoreline. The inset shows parallel crystal beds (dendrites) that probably precipitated from shallow, subaerial surface outflow. (C) Thick stromatolite crusts 'S' coating phonolitic trachyte bedrock, southeastern shore of Ng'wasis. 'Sp' Small shoreline hot spring ( $\left.c a 90^{\circ} \mathrm{C}\right)$; no travertine is present. 'Si' Thin opal-A and trona crusts that coat fracture walls in bedrock. (D) Modern (2008) calcite stromatolites that form on bedrock and gravel, shoreline $2 \cdot 5 \mathrm{~km}$ NNE of Kampi-Ya-Samaki, Lake Baringo (Fig. 1B). 'CC' Modern cyanobacteria undergoing calcification. 'CS' Lithified calcite stromatolite crusts. (E) Geyser KL30 during an eruption (ca 5 m high) during July 2006, when the lake level was relatively low. Discharge, which is highly effervescent and rich in $\mathrm{CO}_{2}$, occurs directly from uncemented deltaic muds: no travertine or sinter is present at the vent. When active, KL30 probably has the highest geyser eruptions in Africa. (F) Steeply bedded, fossil plant tufas at Kipkongor, SE Lake Bogoria. (G) Fossil tufas (late Pleistocene?) capping Pleistocene Molo Tuffs ‘MT' and Hannington Trachyphonolites 'HT' near Maji Moto village, $4.5 \mathrm{~km}$ west of Loburu. The modern springs 'HS' discharge from fractured volcanic bedrock on the valley floor at $\mathrm{T}=37^{\circ} \mathrm{C}$, but no modern carbonates are precipitating there. The tufa is ca $4 \mathrm{~m}$ thick.

that were mediating calcite precipitation. Observations have shown that minor (centimetre-scale) drops in water level or temperature, for example, allow microbial communities to colonize calcite substrates that were previously too hot for mats or biofilms. Later increases in discharge with higher water levels and temperatures rapidly kill some benthic microbes, followed by a return to abiotic calcite crystal growth on the microbial substrate, perhaps induced mainly by $\mathrm{CO}_{2}$ degassing. Most preserved microbial cells and organic exopolymers lie upon crystal surfaces, rather than inside the calcite crystals. Inclusion of microbial remains does not necessarily mean active biomediation of crystal growth if those cells were dead before, or died during, formation of the enveloping crystal. A bacterial role in some of the calcite precipitation is feasible (Casanova \& Renaut, 1987; Casanova, 1994), but the biochemical nucleation mechanism remains unclear and the dominant crystal morphologies are compatible with abiotic growth. Pentecost \& Coletta (2007) and others have shown that, even at lower temperatures, much of the travertine precipitated at thermogene hot springs is probably abiotic, induced by, or accompanying, $\mathrm{CO}_{2}$ degassing from the spring fluid.

The unusual morphology of some of the Loburu travertine deposits may reflect high-disequilibrium crystal growth. Many terrace pools at spring KL6 have a skeletal appearance; they have fully formed rimstone dams, but the floors of most rimstone pools lack aggradational carbonate sediments comparable with those described by Chafetz \& Folk (1984) and others. Rimstone-pool deposits of the type commonly seen in pools at Pamukkale (Ekmekci et al., 1995), Mammoth Hot
Springs (Chafetz \& Folk, 1984) and elsewhere are absent at Loburu. One possible explanation is that the high rate of calcite precipitation at the edge of the rimstone dams, where outflow water degassed $\mathrm{CO}_{2}$ continuously and rapidly by agitation as it flowed as films over the rims, greatly exceeded calcite precipitation on the rimstone pool floors. High fluid temperatures might also have limited microbially influenced calcite precipitation in many pools. This interpretation is supported by the petrographic evidence for dendritic crystal growth on the margins of many pool-rim dams (Fig. 4B).

\section{Age of the travertine formation}

Calcite is precipitating today at spring KL8, and has probably precipitated on the proximal terraces or pool margins of springs KL6 and KL9, and the base of KL10, during the last decade. Several lines of evidence, however, show that most Loburu travertines are relict deposits.

About $80 \%$ of the active hot-spring vents at Loburu lack subaerially exposed carbonates, although their waters are virtually identical in chemical composition to those springs with exposed travertine. The common presence of eroded, mid-Holocene lacustrine stromatolitic limestone crusts on the travertines confirms the antiquity of many of the spring deposits. Those stromatolites, which yielded normalized ${ }^{14} \mathrm{C}$ ages of 4740 to $5290 \mathrm{yr}$ вP (Vincens et al., 1986; Tiercelin \& Vincens, 1987), also encrust calcitearagonite travertines that formed phreatically in the shallow subsurface (at 1 to $5 \mathrm{~m}$ depth?) at Chemurkeu (Fig. 13A and B). This interpretation implies a substantial time gap between travertine 

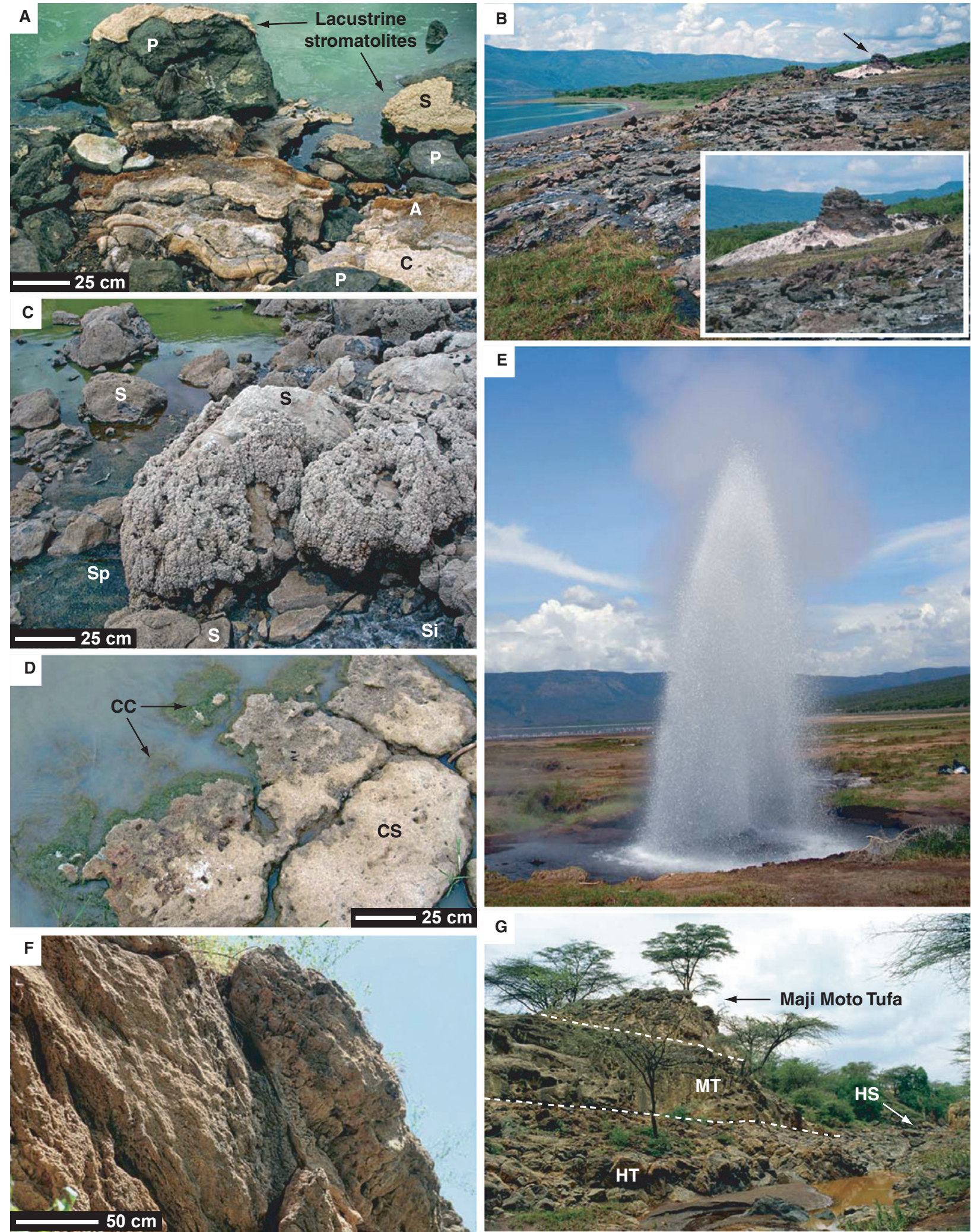

formation and its subaerial erosion, and the later precipitation of lacustrine carbonate crusts.

Radiocarbon ages of $32000 \pm 1900 \mathrm{yr}$ BP and $35000 \pm 3400$ yr BP were obtained for hydrother-

mal calcite at Loburu (Casanova, 1987b). Hardwater effects are expected, but the proportion of isotopically 'old' recycled carbon in the discharged thermal waters would have varied with 
the origin and residence time of the thermal fluids, and the amount of mixing of those fluids with nonthermal ground waters in the subsurface. This inference makes the reliability of these ages difficult to evaluate. Nonetheless, a very similar age of $35 \cdot 5 \pm 2 \cdot 6$ ka was obtained for a 50 g bulk sample of Loburu travertine dated by the U/Th method.

These radiometric ages, obtained using different methods, imply that travertine began to form at Loburu and Chemurkeu at least 5000 years ago. The fossil pool-rim dam of spring KL5f (Fig. 8) had already been eroded and fractured before encrustation by lacustrine stromatolitic crusts, suggesting that the dam is much older than the mid-Holocene stromatolites. During the late Pleistocene to mid-Holocene, lake levels were frequently high in the Bogoria basin (Tiercelin \& Vincens, 1987), but the pool-rim dam of spring KL5f clearly formed subaerially and might therefore pre-date those phases of high lake level. From their state of preservation, fracturing and erosion, and the known history of the lake, most of the exposed travertines at Lake Bogoria probably formed during the late Pleistocene, and could be as old as their radiocarbon and U/Th ages of $c a 32$ to $35 \mathrm{ka}$.

Those springs with well-developed travertine deposits, such as KL6, KL8, KL9 and KL5f, are probably the oldest vents at Loburu and likely have mature plumbing systems with circulating fluids that today have relatively low residence times. Although spring fluids still flow from their vents, they have little impact on the substrates. Most spring waters are saturated with respect to $\mathrm{CaCO}_{3}$, but modern carbonate precipitation remains minor, and the high $\mathrm{pH}$ of the outflow inhibits corrosion of the older travertine.

\section{Environment of travertine formation at Loburu}

The morphology of most of the travertine deposits, including the pool-rim dams, terraces and channel-floor sediments, is fully compatible with subaerial rather than sublacustrine precipitation. Carbonates precipitated around submerged springs commonly have chimney-like and domal morphologies, or form encrustations on the substrate (Fontes \& Pouchan, 1975; Savascin \& Birsoy, 1993; Stoffers \& Botz, 1994; Pentecost, 2005; Guido \& Campbell, 2011; Guo \& Chafetz, 2012). Most Loburu travertine mounds lack evidence for subaqueous formation. The small chimneys that once capped the mound at spring KL14a (Fig. 9D) are a possible exception; their isotopic composition (Fig. 12B), which suggests precipi- tation from mixed fluids, implies that some travertine was still precipitating during the period of submergence by the rising lake and colonization by microbial mats. In contrast, the abrupt change in isotopic composition in the crusts that cap the fossil pool-rim dam of KL5-f (Fig. 12B) implies that travertine precipitation had already ceased at that site when cyanobacterial mats covered the submerged travertine substrate. The isotopic enrichment in the stromatolitic crusts may be related to evaporative concentration and the residence time of the lake water (for a discussion, see Casanova, 1986; Casanova \& Renaut, 1987). Furthermore, in a proximal subaqueous deltaic setting, suspended silt and clay settling on the shallow lake floor might contaminate travertine forming subaqueously in shallow lake water (except around vents with strong fluid upflow). Although a few thin siliciclastic interbeds are present, most travertines are fairly pure, supporting subaerial precipitation.

An important question of interpretation is whether the Loburu travertines all formed during a single phase of precipitation or in several phases that were separated by intervals with little or no carbonate precipitation. Most evidence favours the latter interpretation. Calcite dendrites can form incrementally, but the bedded large $(>10 \mathrm{~cm})$ dendrites in the pool-rim dam of KL5f (Fig. 8E) and elsewhere show few obvious discontinuities. Growth rates of calcite dendrites are unknown, but thermogene travertine typically forms rapidly (Pentecost, 2005). Breaks and changes in style of travertine precipitation would be expected, however, when the springs respond to varying lake level. During periods with little or no precipitation, some travertines were subaerially eroded, as shown by angular discontinuity surfaces; at other times, they were submerged and covered by deltaic sediments that protected them from erosion. Precipitation of modern calcite upon much older deposits (Fig. 11G) and recent exhumation of old travertines (Fig. 7D and E) are also evidence of separate phases of precipitation.

The factors that promoted carbonate precipitation at some times but not at others are difficult to determine. Periods favourable for travertine formation are recorded at many sites worldwide (Sorey et al., 1991; Pentecost, 2005; Viles et al., 2007). In some places, travertine formation has been linked to increased rainfall (Minissale et al., 2002; Johnson et al., 2009), changing ground water temperature (Dramis et al., 1999), or the transition from humid to drier conditions 
(Marker, 1971; Bonny \& Jones, 2003). At Loburu, the location of the springs on the shores of a closed saline lake that fluctuates frequently in surface level complicates interpretations linked to climate change. A simple increase in rainfall alone, for example, cannot explain travertine formation because the rising lake water would drown most spring vents. As noted, however, most morphological evidence confirms that the deposits formed subaerially. At some time in the past, the travertine seems to have formed when the lake level was at about the same relative elevation as today.

Studies of the Pamukkale hot springs in Turkey by Dilsiz et al. (2004) provide a possible explanation for time-variable precipitation of hydrothermal carbonates that may apply, in part, to the Lake Bogoria travertines. Dilsiz et al. (2004) suggested that phases of thermogene travertine precipitation in a $\mathrm{CO}_{2}$-rich spring system can be related to temporal changes in the depth of the boiling zone and to associated changes in the carbonate mineral saturation levels of the rising spring fluids. Those changes, in turn, can be linked to climate variability, especially the amount of rain falling in the catchment and the volume of cool ground water that mixes with the deeper thermal fluids that are rising to the surface. Dilsiz et al. (2004) showed that subaerial travertine formation should be favoured when the boiling zone is shallower during humid phases, whereas carbonates are more likely to precipitate underground during drier phases when the water table falls, fluid mixing declines and the boiling zone becomes deeper. Rihs et al. (2000) used similar arguments to explain phases of travertine precipitation in the Massif Central of France.

Although the hydrogeology of the Bogoria geothermal system is unresolved (Allen et al., 1989; Clarke et al., 1990; Cioni et al., 1992; Hochstein, 1999), a shallow boiling zone is evident. Most Loburu springs emerge at temperatures of $>90^{\circ} \mathrm{C}$, many are boiling at the vent, and at least 18 geysers have been active at Lake Bogoria during the past 35 years (Renaut et al., 2008). Deep thermal fluids charged with $\mathrm{CO}_{2}$ and other gases, some perhaps derived from mantle sources (Darling et al., 1995, 1996), underlie parts of the Kenya Rift floor, including the region near Lake Bogoria. Fumaroles at Arus (Fig. 1B) discharge up to $99 \% \mathrm{CO}_{2}$ (Walsh, 1969). The deeper, hot $\mathrm{CO}_{2}$-rich fluids ascend, mainly along faults and fractures, where they mix with relatively cool, shallower dilute ground waters of $\mathrm{Na}-\mathrm{Ca}-$ $\mathrm{HCO}_{3}$ composition at various depths on their way to the surface. These heated fluids then discharge at the surface as hot springs. Some undergo nearsurface boiling where the hydrostatic pressure decreases (Rinehart, 1980). Although the depth of first boiling and exsolution of vapour and gases (mainly steam and $\mathrm{CO}_{2}$ ) is unclear, near-surface and surface boiling and associated $\mathrm{CO}_{2}$ outgassing are potentially important controls of carbonate precipitation at Loburu. The saturation state of the ascending fluids with respect to carbonate minerals and silica will vary mainly with their $\mathrm{PCO}_{2}, \mathrm{pH}$, temperature, pressure, flow velocity, and the amount of interaction between those fluids and the volcanic and sedimentary wall rocks (i.e. hydrothermal alteration) during their ascent (Fournier, 1985; Giggenbach et al., 1994; Simmons \& Christenson, 1994; Darling et al., 1996; Pirajno, 2009). Changes in one or more of these controlling factors determine whether mineral precipitation will occur, its composition, and whether it happens underground or at the contemporary land surface.

Fluctuations in the depth(s) of boiling and related changes in fluid chemistry might explain the origin of some of the spring deposits at Lake Bogoria. During relatively arid conditions, the lake level will be low, the volume of hydrothermal circulation and surface discharge should decrease, and the amount of mixing between the rising thermal fluids and the cooler shallow ground waters will decline because of the lower recharge from rainfall (Fig. 14A). The $\mathrm{CO}_{2}$ concentration of the deeper rising thermal fluids might increase during arid phases because of the decrease in dilute recharge, and the boiling zone would be relatively deep because of the reduced pressure on the thermal water column. High concentrations of $\mathrm{CO}_{2}$ in the subsurface fluids could produce acidity at depth (Dilsiz et al., 2004). Saturation with respect to $\mathrm{CO}_{2}$ might also induce degassing at depth (Rihs et al., 2000), with further loss of $\mathrm{CO}_{2}$ occurring during boiling when the rising fluids move towards the surface. Boiling and $\mathrm{CO}_{2}$ exsolution, in turn, should initially induce an abrupt rise in $\mathrm{pH}$, and the supersaturation and precipitation of $\mathrm{CaCO}_{3}$ (possibly as platy calcite or aragonite?) mainly in the conduits directly above the boiling zone (Fig. 14A). Fluids depleted in $\mathrm{Ca}^{2+}$ would then discharge at the surface either as $\mathrm{Na}-\mathrm{HCO}_{3}$ spring waters with a high $\mathrm{CO}_{2}$ flux or as $\mathrm{CO}_{2}$-rich fumaroles at slightly higher elevations (Fig. 14A). Fluid reactions with wall rocks en route to the surface would also be likely to control aqueous $\mathrm{CO}_{2}$ concentrations, partly because of the reduction in Ca-bearing 


\section{A Arid conditions}
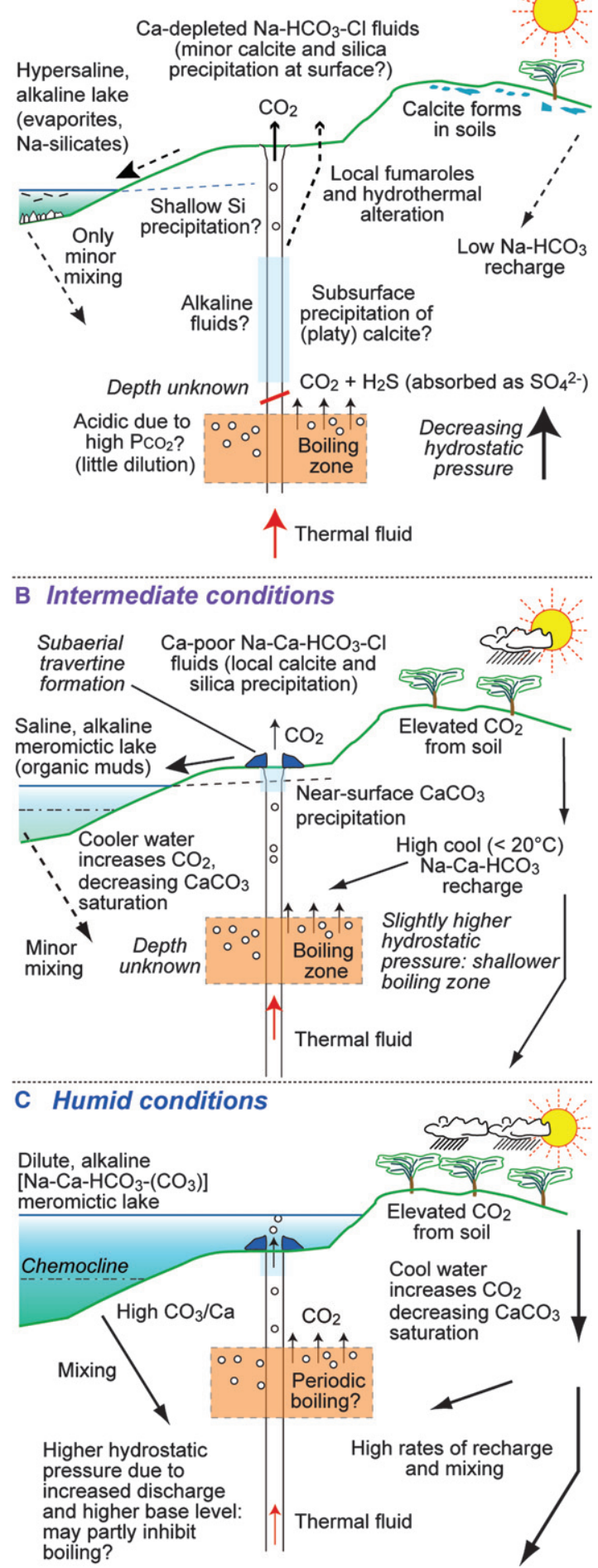

Fig. 14. Schematic model to show the inferred processes and controls of carbonate precipitation at the Loburu hot springs under different climate conditions and associated lake levels. The boiling zone is probably 'shallow', but its actual depth is unknown. Boiling at Loburu occurs at much shallower depths and over a much narrower vertical range than those inferred by Dilsiz et al. (2004) at Pamukkale, although similar principles may apply. dilute recharge. Relatively arid conditions, therefore, would have been generally unfavourable for subaerial travertine precipitation at Loburu.

In contrast, during more humid conditions, higher rainfall and infiltration of runoff should enhance the advective hydrothermal circulation and promote high fluid-discharge rates in the thermal areas (Sturchio et al., 1993; Rihs et al., 2000). The rising thermal fluids would vary from undersaturated to saturated with respect to $\mathrm{CaCO}_{3}$ because of their greater, but variable, mixing with shallow, cooler, dilute ground water. Cooling during fluid mixing would increase the solubility of $\mathrm{CO}_{2}$ and $\mathrm{CaCO}_{3}$. However, the nearsurface boiling zone would then be shallower because the pressure on the rising thermal water column is greater, following more mixing with the cooler, denser ground water, and the water table would be higher with the increased rainfall (Dilsiz et al., 2004). Rapid degassing of $\mathrm{CO}_{2}$ at and near the surface might then lead to phases of $\mathrm{CaCO}_{3}$ precipitation at the vent and in the shallow subsurface above the boiling zone (Fig. 14B).

Although an increase in rainfall might favour travertine precipitation in some settings, the location of Loburu on the shoreline of a closed basin lake means that any substantial or prolonged increase in rainfall will lead to submergence of the hot springs and dilution of the lake water (Fig. 14C). During such times, both the spring and lake waters might have contained more $\mathrm{Ca}^{2+}$ than today because of the enhanced weathering rates, greater runoff and increased rates of dilute recharge of shallow ground waters. At Lake Bogoria, very little travertine precipitated subaqueously while the spring vents were submerged. With one exception (KL14a), the stable isotope evidence does not support precipitation from mixed fluids (i.e. mixed spring and lake water) (Fig. 12). The fluids emerging from lake floor vents might not have been sufficiently saturated for extensive calcite precipitation: cooler fluid temperatures, the partial suppression of boiling and associated $\mathrm{CO}_{2}$ degassing due to the increased fluid pressure (?), and rapid mixing with dilute lake water might have reduced the potential for sublacustrine travertine precipitation focused around the submerged vents. Nonetheless, carbonate was precipitated subaqueously as lacustrine stromatolitic crusts (Fig. 13A and C), probably biomediated by an oscillatorian such as Phormidium (Casanova, 1986). Similar calcified stromatolites, up to $3 \mathrm{~cm}$ thick, are today forming periodically on volcanic bedrock and gravel along 
the north-western shoreline of Lake Baringo, $2.5 \mathrm{~km}$ north of Kampi-Ya-Samaki (Figs 1B and 13D; Tarits et al., 2006). Lacustrine calcite stromatolites formed on submerged travertines at Loburu where the rising spring waters were cooled sufficiently by the Ca-bearing lake water. The thickest stromatolite crusts at Lake Bogoria $(>25 \mathrm{~cm}$ thick) lie along the south-eastern shoreline of Ng'wasis (Fig. 1C), near a site of many present and former shoreline hot springs, but no subaerial travertine is present there (Fig. 13C).

Minor calcite is precipitating at several modern springs, so environmental conditions similar to those today might have existed during the main phase(s) of travertine development. However, the scale of the deposits and the large dendritic crystals imply that, at times, conditions more favourable than those of today might have occurred. The Loburu travertines seem to have formed at times when the lake level, relative to the hot springs, was similar to that today. During those periods, however, the spring waters might have contained more $\mathrm{Ca}^{2+}$ than the modern fluids and (or) physicochemical conditions might have favoured more extensive or more rapid calcite precipitation. When water overflowed the poolrim dams of springs KL6 and KL5f (Figs 5A and 8), spring water levels would have been $c a 60 \mathrm{~cm}$ higher than today (July 2009). In contrast, the lake level would have been at least $75 \mathrm{~cm}$ lower than the present level when the small travertine mounds (Fig. 9H), now submerged offshore, were forming subaerially.

The period(s) when conditions favoured travertine precipitation at Loburu might have occurred during 'intermediate' lake levels (ca $990 \mathrm{~m}$ above sea-level), similar to those today (Fig. 14B). The transition from humid to drier conditions could have been optimal for carbonate precipitation. During such times, the lake level would be gradually falling, dilute recharge and mixing with hydrothermal fluids would decline, and reduced recharge from runoff might lower the boiling zone, perhaps inducing more shallow, subsurface calcite precipitation. Under such conditions, the discharged fluids might initially precipitate subaerial calcite but the amount of carbonate precipitation might decrease as the total Ca concentration in the spring water gradually declined. Today, however, the low salinity of the modern fluids ( $<5 \mathrm{~g} \mathrm{l}^{-1}$ TDS) implies only limited fluid-rock interaction and a low residence time during subsurface water circulation. The sensitivity of the spring behaviour to even minor changes in lake level is nonetheless confirmed by the behaviour of geyser KL30 at southern Loburu, which erupted to $5 \mathrm{~m}$ in height every $45 \mathrm{~min}$ in 2006 following a $\mathrm{ca} 30 \mathrm{~cm}$ fall in lake level (Fig. 13E), but the vent became a quiet hotspring pool $\left(\mathrm{T}\right.$ : $93^{\circ} \mathrm{C}$ ) between 2007 and 2009 following a minor $(<30 \mathrm{~cm})$ rise (Renaut et al., 2008, fig. 4), and was fully submerged and inactive in July 2011.

Climate is only one control of travertine formation. Changes in the hydrogeology of the geothermal system and neotectonics could also have played a role, but are very difficult to assess. Arnórsson (1989), for example, showed that calcite precipitation in geothermal wells also occurs in phases. Arnórsson noted that maximum $\mathrm{CaCO}_{3}$ saturation occurs with the rapid decrease in $\mathrm{PCO}_{2}$ soon after boiling begins, but that prolonged boiling and loss of enthalpy gradually leads to cooling, followed by reduced levels of $\mathrm{CaCO}_{3}$ supersaturation. This cooling effect could potentially be a factor in travertine formation at Loburu. Periodic changes in shallow boiling conditions, linked perhaps to temporal fluctuations in fluid mixing, might have contributed to phases of subaerial calcite precipitation. Similarly, intrinsic changes in the subsurface $\mathrm{CO}_{2}$ concentration, unrelated to climate change or surface recharge of the aquifers, could also have been a factor in travertine formation (see D'Alessandro et al., 2007). An increase in $\mathrm{CO}_{2}$ concentration, linked for example to rifting processes, could lead to boiling at progressively greater depths for a given temperature in a geothermal fluid reservoir (Mahon et al., 1980; Nicholson, 1993). Such changes, in turn, might affect both where and when any carbonate precipitation occurs.

Tectonics also cannot be discounted as an influence on travertine formation because the springs lie along fault lines or major fracture zones (Fig. 2). Northward tilting and regional subsidence of the rift floor occurred in the study area during the late Pleistocene (Le Turdu et al., 1999). The region is seismically active (Young et al., 1991), and the epicentre of a large earthquake (magnitude 6.9) in 1928 was located only $12 \mathrm{~km}$ NNW of Loburu (Ambraseys, 1991; Zielke \& Strecker, 2009). Changes to the hydrogeology and chemistry of the fluids in the spring plumbing system, resulting from faulting or extensional processes that either created or closed fractures, could have played a role in carbonate precipitation (see Brogi et al., 2010). Historic earthquakes have affected the behaviour of other thermal springs in the Kenya Rift (Crane, 1981). 
It could be argued that Lake Bogoria was hydrologically open during travertine formation, so would not have risen in surface level even if increased rainfall recharged and diluted both the lake and spring water, and increased the Ca concentration of the spring fluids. The lake might have drained northwards recurrently during the latest Pleistocene and Holocene (Tiercelin \& Vincens, 1987), but its surface would have been ca $9 \mathrm{~m}$ higher than its present level during any Holocene overflow (i.e. at $999 \mathrm{~m}$ above sea-level), so Loburu delta would then have been fully submerged and the travertine could not have formed subaerially. With current evidence, the impact of neotectonics and changes in drainage basin morphology on travertine formation is difficult to assess, but those influences do not appear to have been the major controls on carbonate precipitation at the Loburu springs.

\section{Implications of the results}

Although the relation between travertine formation and climate change has not been fully resolved at Lake Bogoria, lake-level changes, if sustained, clearly might impact the timing of carbonate precipitation. Conditions for calcite precipitation at the Loburu springs are partly controlled by lake level and climate (Fig. 15).

When the climate is too wet or too dry, travertines do not form around the lake shoreline. If conditions are too humid, lacustrine carbonates may form instead; if too arid, carbonates either precipitate in the subsurface or do not form because of increasing acidity and (or) the decreased Ca supply. Some springs stop flowing during dry periods. Others become steam vents, $\mathrm{CO}_{2}$ fumaroles or inactive (based on observations). Some springs migrate to lower elevations in the basin and flow from new vents (Nelson et al., 2001). The offshore travertine mounds (Fig. 9H), which formed subaerially during a former period of lower lake level, confirm that vent locations migrate when the lake level falls. In contrast, vents at Koibobei (Fig. 1C) that had been dry for two decades discharged boiling water after the lake level had risen ca $1 \mathrm{~m}$ during the year preceding July 2011.

An important consequence is that: (i) hotspring carbonate precipitation along closed-lake shorelines probably occurs only when the lake level lies within a small vertical range in elevation, termed here the 'travertine window' ( 1 to $3 \mathrm{~m}$ at Loburu, extending from ca 989 to $992 \mathrm{~m}$ above sea-level; Fig. 15D); and (ii) carbonate precipitation may recur on multiple occasions whenever the lake level lies within that zone, as has been the case for the past three decades. The preserved shoreline travertine record, therefore, may be cumulative, consisting of multiple generations of carbonates that formed at different times whenever the lake surface stood (in this case study) at intermediate elevations. The radiometric dates imply that much of the exposed travertine at Loburu formed during a period of spring carbonate precipitation at $c a 30$ to $35 \mathrm{ka}$, but that some of the travertine is very recent (Fig. 7).

In common with many other closed-basin lakes, the vertical range of the lacustrine stromatolite encrustation around the shoreline is also under similar climate and palaeohydrological controls (Fig. 16). If the lake level is relatively high and the lake maintains open hydrology, its waters are typically dilute and may be either undersaturated or insufficiently saturated with respect to $\mathrm{CaCO}_{3}$, so that carbonate stromatolites do not form. During such times, fine suspended sediments from deltaic inflow may increase nearshore turbidity, reduce the littoral photic zone and locally inhibit stromatolite formation. In contrast, when the lake level is low, the lake water in some basins becomes calcium depleted as both salinity and alkalinity increase; this is because much of the $\mathrm{Ca}^{2+}$ is removed in the drainage basin as surface and shallow subsurface carbonate cements, by calcrete formation, and by other fractionation processes (Eugster \& Jones, 1979; Jones \& Deocampo, 2003). High salinity can exclude many cyanobacteria that mediate calcite precipitation, and authigenic clay formation in the water column may reduce the depth of the photic zone, which probably occurs today in north-western Lake Baringo (Tarits et al., 2006). Thick (up to $3 \mathrm{~cm}$ ) planktonic microbial scums, which commonly accumulate along the margins of the highly productive saline, alkaline lakes of the Kenya Rift, also reduce the depth of the littoral photic zone.

The total vertical zone in which stromatolites can form in closed-basin lakes is termed here the 'stromatolite window' (Fig. 16A). At Lake Bogoria, the mid-Holocene stromatolite window extended from a ca $1 \mathrm{~m}$ below the present lake level of $c a 990 \mathrm{~m}$ (based on observation) up to $c a 997 \mathrm{~m}$ elevation, which is $c a 2 \mathrm{~m}$ below the level at which the lake will overflow northwards. It is important to note, however, that recent (post1976) lake levels lie within the Holocene stromatolite window, but littoral lacustrine stromatolites are not forming today. Those present along the modern shoreline formed during 
A

Local graben Trachyphonolites

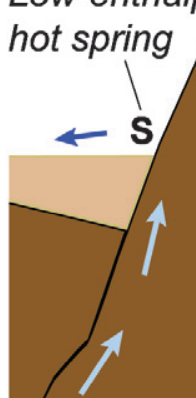

Dilute warm, thermal fluids

Moderate meteoric recharge

Fault block

\section{Intermediate lake level}

Periodic travertine formation at the surface and in the shallow plumblng system

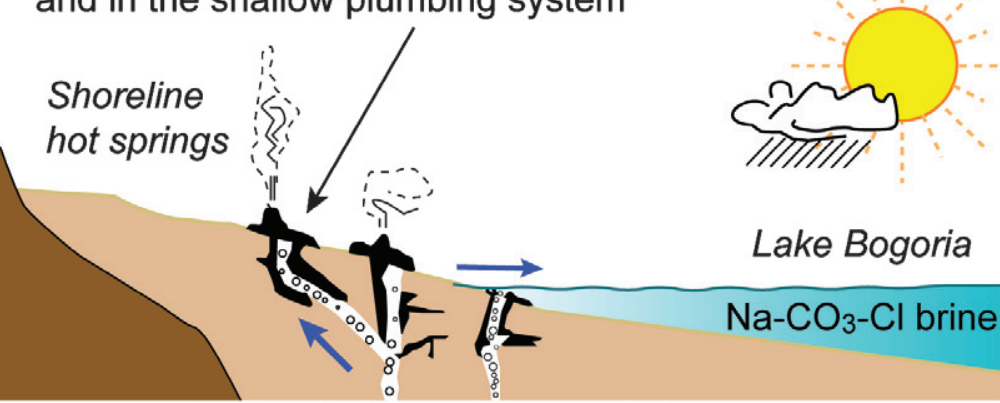

Shallow boiling - $\mathrm{CO}_{2}$ exsolution

B

High lake level

Tufa

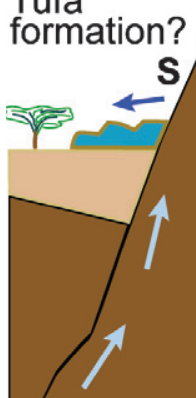

Periodic siliciclastic influx

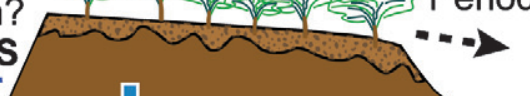

Lacustrine stromatolites form
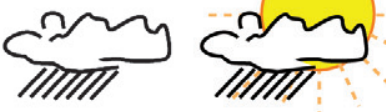
upon stable substrates

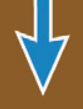

High meteoric recharge
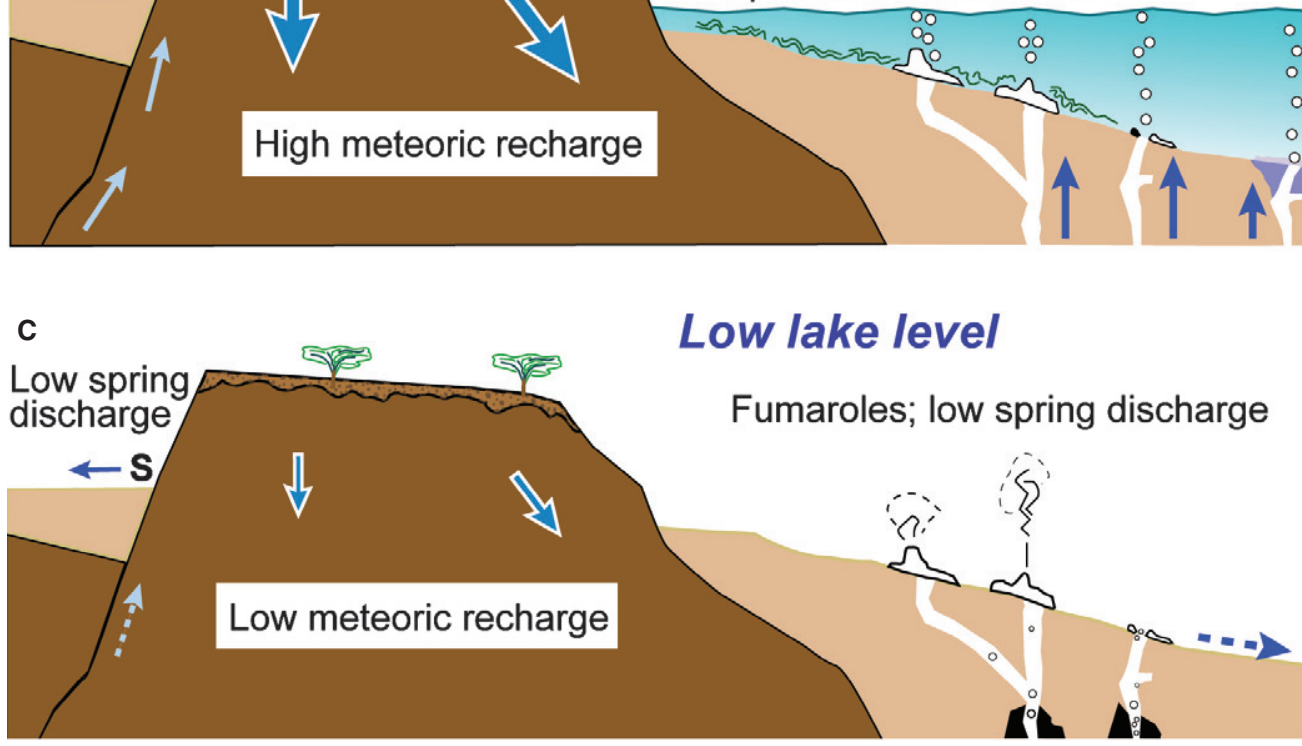

Dilute to brackish $\mathrm{Na}-\mathrm{Ca}-\mathrm{HCO}_{3}$ lake water

Silica precipitation

\section{Spring carbonates vs. Lake level}
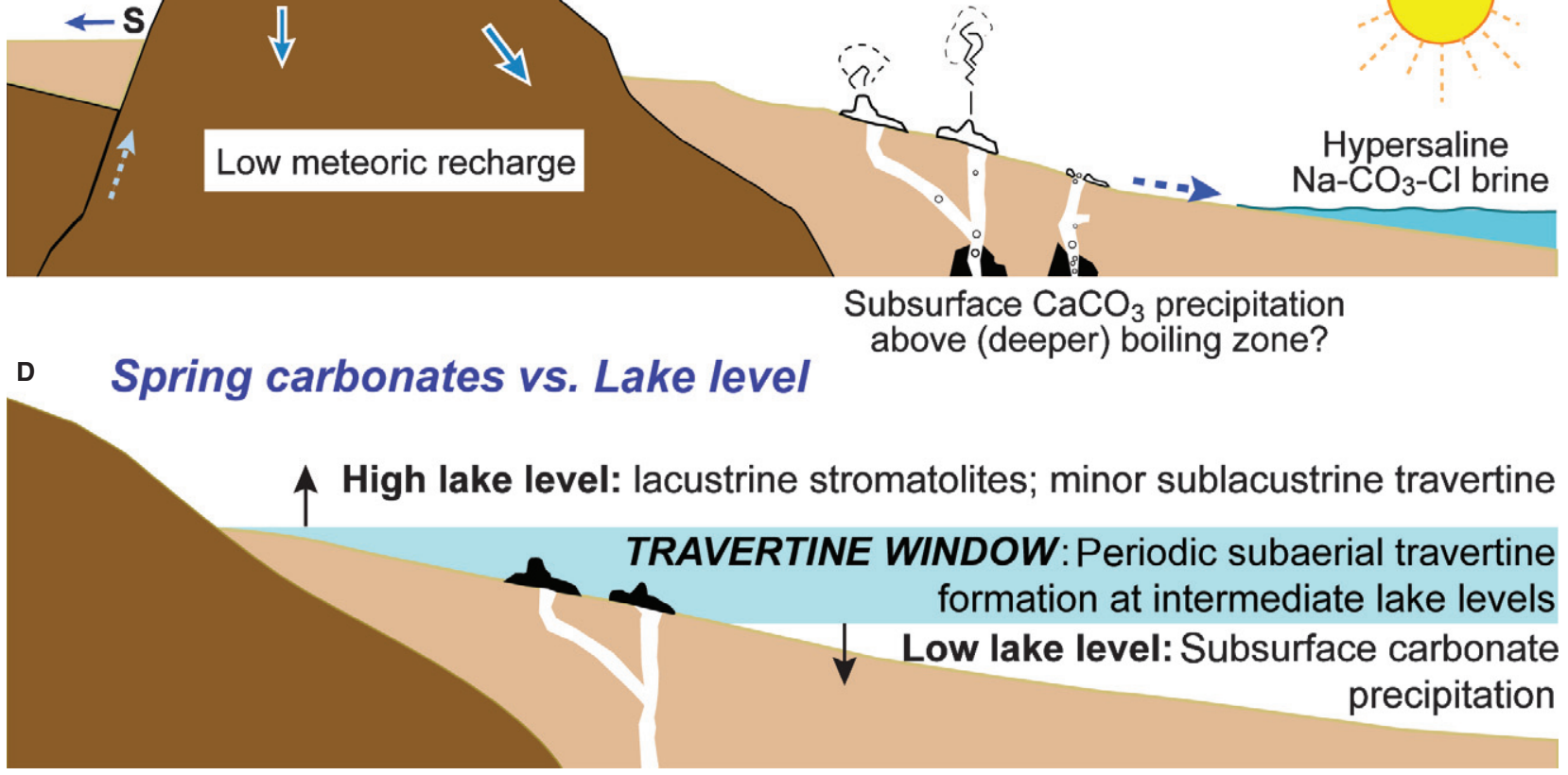

Fig. 15. Summary of the inferred relations between lake-level changes and travertine formation at Lake Bogoria, and the concept of a 'travertine window'. 
Shoreline

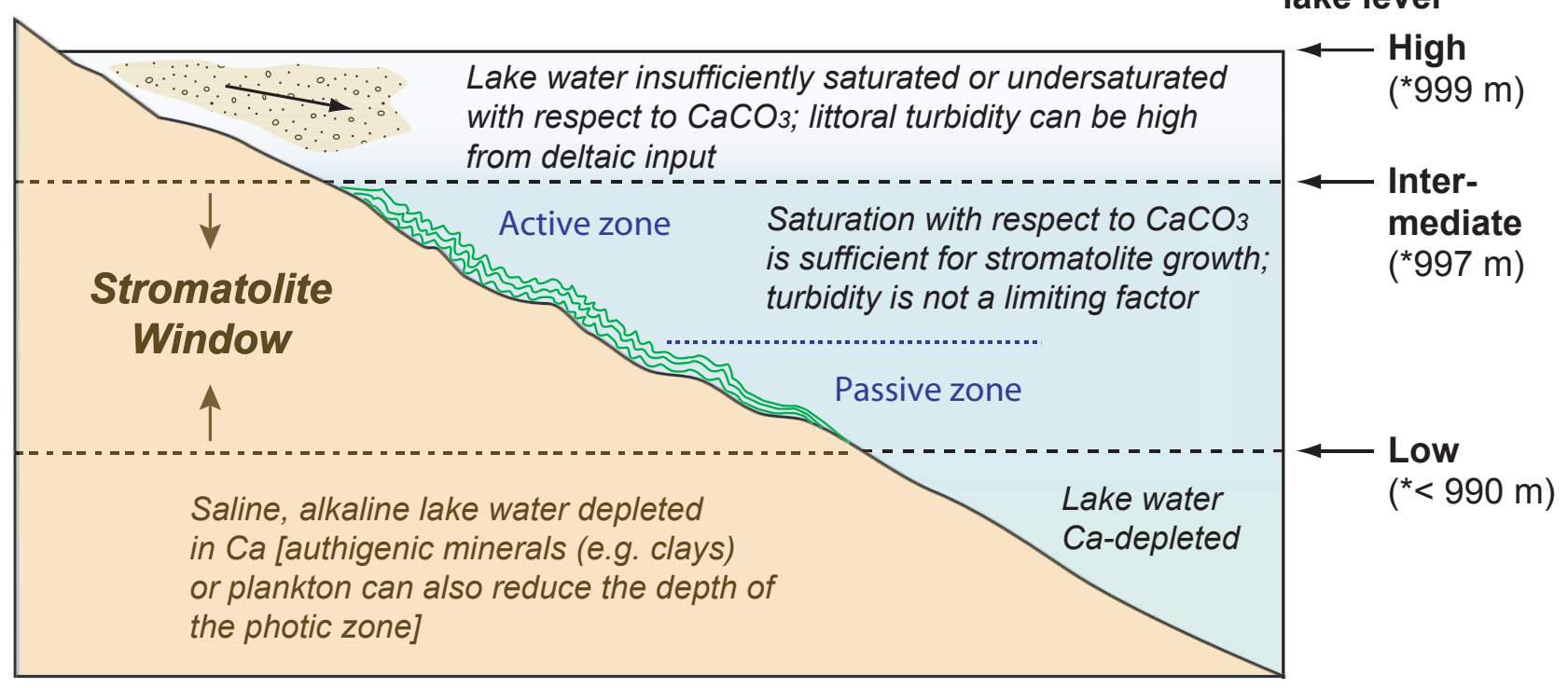

Relative

lake level

$\longleftarrow$ High

$\left({ }^{*} 999 \mathrm{~m}\right)$

mediate

Saturation with respect to $\mathrm{CaCO}_{3}$ is sufficient for stromatolite growth; turbidity is not a limiting factor

( ${ }^{*} 99 \mathrm{X}$ m: Approximate levels at Lake Bogoria)

Fig. 16. Concept of the 'stromatolite window' in closed saline, alkaline lakes. Carbonate stromatolites (calcite, aragonite, dolomite or Mg-carbonates) are limited to a specific range in elevation around the shoreline that varies from lake to lake. That range is controlled mainly by the lake water chemistry (especially Ca ${ }^{2+}$ availability). Other factors, such as turbidity, organic productivity and its impact on the depth of the photic zone, and toxins at high salinities, can all control the vertical limits, range, thickness and morphology of stromatolite (or thrombolite) formation around the shoreline or across the lake floor. Shoreline slope controls the lateral extent of the stromatolites. In deep saline, alkaline lakes, the stromatolite window may be a restricted zone around the lake margins; in shallow lakes, however, the entire lake floor may fall within the 'stromatolite window' depending on the lake hydrochemistry and hydrology. Dilute Ca-bearing ground water seepage along lake shorelines often controls the location of the microbialites that lie within the stromatolite window.

earlier phases of deeper, more dilute, clearer lake water. The 'active stromatolite window' is the full vertical range of lake levels within which stromatolites actively form around lake shorelines. The 'passive stromatolite window' represents the lower extension of the active stromatolite window. In the passive stromatolite window, carbonate stromatolites are present but they formed when the lake level was higher. No stromatolites form when the lake level lies below the interface of the active and passive zones. In ancient lacustrine sediments, therefore, the lower part of the stromatolite window does not necessarily mean that stromatolites were still forming when the lake surface stood at that same elevation (Fig. 16). Variations in the stromatolite morphology (Casanova, 1986, 1994), however, may help to resolve relative water depths during stromatolite formation.

The concept of the stromatolite window is already well-known from many other closedbasin lakes, especially those that have, or once had, saline alkaline waters. Arenas \& Pardo
(1999), for example, referred to a 'stromatolite fringe' in Oligocene-Miocene lacustrine sedimentary rocks of the Ebro Basin, Spain. Many analogous examples are known from Quaternary lake deposits in East Africa (Icole et al., 1990; Casanova, 1994; Cohen et al., 1997), in the western USA (Benson, 1978; Petryshyn \& Corsetti, 2011), and many places elsewhere. Significantly, the stromatolite window can be approached from both directions, each with contrary interpretations. In some lakes, the stromatolites record a transition from wetter to drier (often more saline) conditions and a lower lake level (Grove et al., 1975; Solari et al., 2010); in other basins, the stromatolites record a change from saline to fresher waters, linked to more humid conditions and (or) rising lake levels (Casanova, 1986, 1994).

The relation of the Loburu travertines to those at Chemurkeu is unclear. Travertines at both sites share similar crystal morphologies, but those at Chemurkeu lie up to $c a 4.5 \mathrm{~m}$ above the highest modern Loburu hot spring. The highest traver- 
tines at southern Chemurkeu are bedded and probably precipitated subaerially (Fig. 13B). In contrast, those exposed along the modern (2009 through to 2011) shoreline precipitated below the contemporary land (or lake floor?) surface in a shallow, subsurface plumbing system when the lake level was several metres higher than at present (perhaps then at 993 to 997 m elevation?) (Fig. 13A; Jones \& Renaut, 1998; Renaut \& Jones, 1997, fig. 4). When those dendritic, skeletal and platy crystals were forming, the boiling zone was probably shallower than that of today because both lake level and hydrostatic pressure were then higher at Chemurkeu. Unlike Loburu, the Chemurkeu springs flow from narrow ( 0.5 to $5 \mathrm{~cm}$ wide) fractures in phonolite on a steep shoreline, rather than from permeable sediments at a few metres lower elevation. Differences in the plumbing and fluid pressure (i.e. partly confined at Chemurkeu versus unconfined at Loburu) might have influenced the range of elevation of spring discharge and expanded the travertine window at Chemurkeu, enabling springs to discharge at higher elevations than at Loburu.

A U/Th age of $32.9 \pm 1 \cdot 22 \mathrm{ka}$ was obtained for a $50 \mathrm{~g}$ bulk sample of the Chemurkeu travertines, implying that the latter deposits formed at about the same time as those at Loburu (i.e. 32 to $35 \mathrm{ka}$ ). When the highest travertines at Chemurkeu were forming, however, Loburu delta must have been fully submerged (assuming no later northward tilting, differential subsidence or faulting at Loburu) so the relict travertines at each site may be of similar age, but not fully contemporaneous.

Where thermal spring fluids have been in shallow circulation but have not boiled or reacted much with bedrock, they retain some $\mathrm{Ca}^{2+}$ and, being cooler, can retain more $\mathrm{CO}_{2}$. Calcite then precipitates extensively at subaerial springs upon $\mathrm{CO}_{2}$ degassing, both at the vents and for a few hundred metres downstream, with or without microbial mediation (Johnson et al., 2009; Pedley \& Rogerson, 2010). Examples include several large tufa-travertine deposits at Emsos, Kipkongor and Maji Moto (Figs 1C, 13F and G). Those too are clearly relict deposits, with a radiocarbon age of ca 21 ka obtained for tufa at Maji Moto (Casanova, 1987b). The fluids discharged at those springs share the same heat source as the high-enthalpy springs at Lake Bogoria, but have probably undergone shallower circulation, less heating and less mixing with deeper geothermal fluids. The tufas, which are somewhat enriched in ${ }^{18} \mathrm{O}$ compared with the shoreline travertines (Fig. 12A), might have precipitated from fluids that evolved from mixing of deep hydrothermal fluids with more dilute thermal ground waters in a relatively shallow aquifer. Little, if any, carbonate precipitates at these springs and in their outflow channels today; their deposits might have formed periodically during more humid periods when thermal fluid circulation was enhanced (Fig. 15B) or during a transition from wetter to drier conditions. The age of the youngest tufas is unknown. Most are weathered and incised.

An unusual feature of the modern Loburu springs is that both calcite and opaline silica coprecipitate from the same thermal fluids, but usually at different sites. Such co-precipitation is usually restricted to high-enthalpy travertine springs because very high temperatures are needed to mobilize the silica. Highly alkaline fluids (i.e. $\mathrm{pH}>9$ ), such as those present in the East African Rift, could also have high very silica concentrations, but normally such fluids would be Ca-depleted. Co-precipitation of calcite and opaline silica occurs at Lorusio hot springs in the northern Kenya Rift and elsewhere (see, for example, Allen, 1934; Canet et al., 2005; Guido \& Campbell, 2011). Such springs did not always discharge at very high temperatures at the land surface, but most were partly fed by fluids that were at high temperatures in the subsurface. At Loburu, the carbonates and Mg-silicates precipitate subaqueously near vents, whereas most silica forms in cooler settings downstream or around pool margins (Fig. 17), typically upon microbial substrates. This spatial distribution follows the $\mathrm{pH}$ and temperature controls on their respective mineral solubilities. Calcite, with retrograde solubility, precipitates in the hottest waters near the vent where most $\mathrm{CO}_{2}$ exsolution probably occurs. The $\mathrm{CaCO}_{3}$ saturation levels should then progressively decline in cooler waters downstream where travertine is absent. The Mg-silicates coprecipitate in proximal alkaline waters with calcite, but soon become limited downstream by the decreasing Mg availability. The silica concentration of the modern spring fluids, which is probably controlled by chalcedony solubility (Cioni et al., 1992), is too low for subaerial silica precipitation as opal-A upon cooling alone (Fig. 17B), so sinter has not formed around the vents at Loburu. Silica, which becomes less soluble with distance from the vent where effluent fluids cool and undergo strong evaporative concentration, precipitates mainly upon microbial surfaces (Renaut et al., 1998) or, in ponded sites, polymerizes to form thin ( $<5 \mathrm{~mm}$ thick), bluish grey, milky gels. At alkaline hot springs 


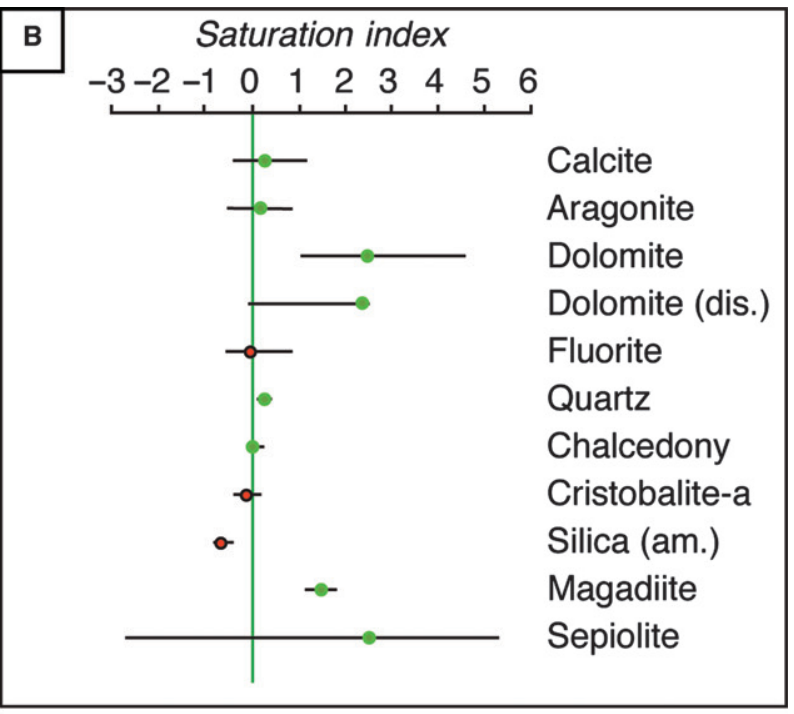

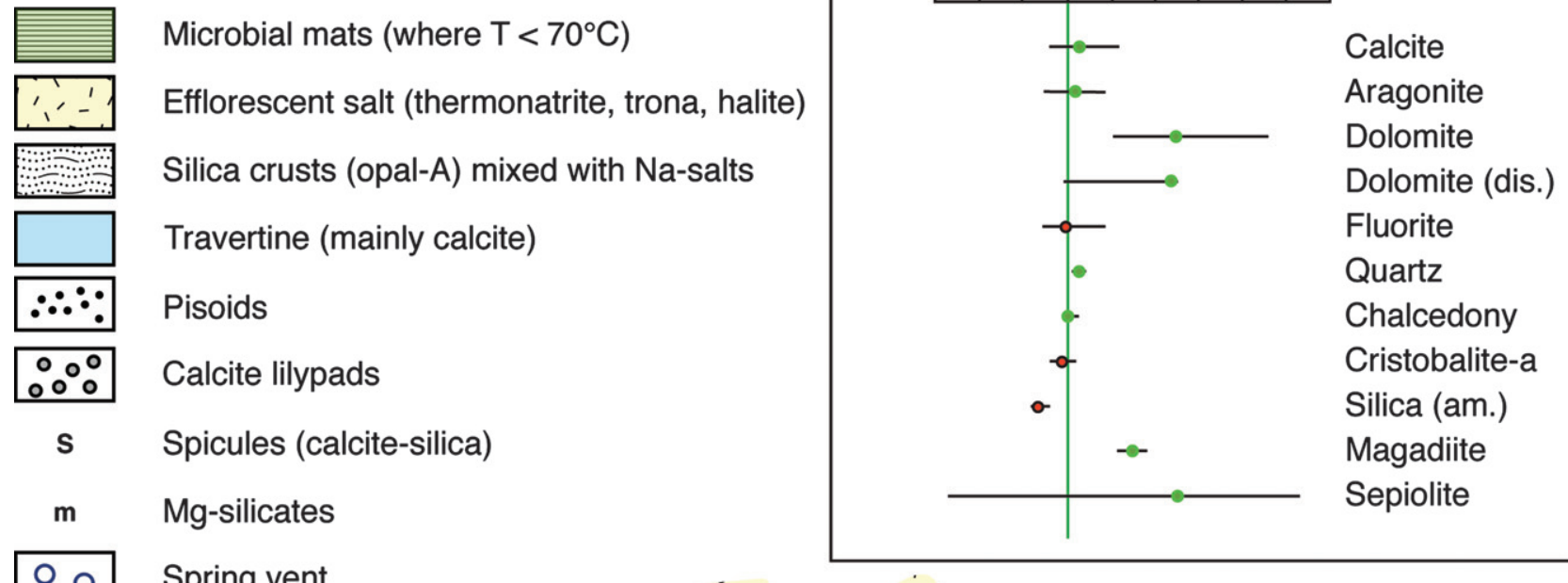

$\bigcirc \circ$ Spring vent

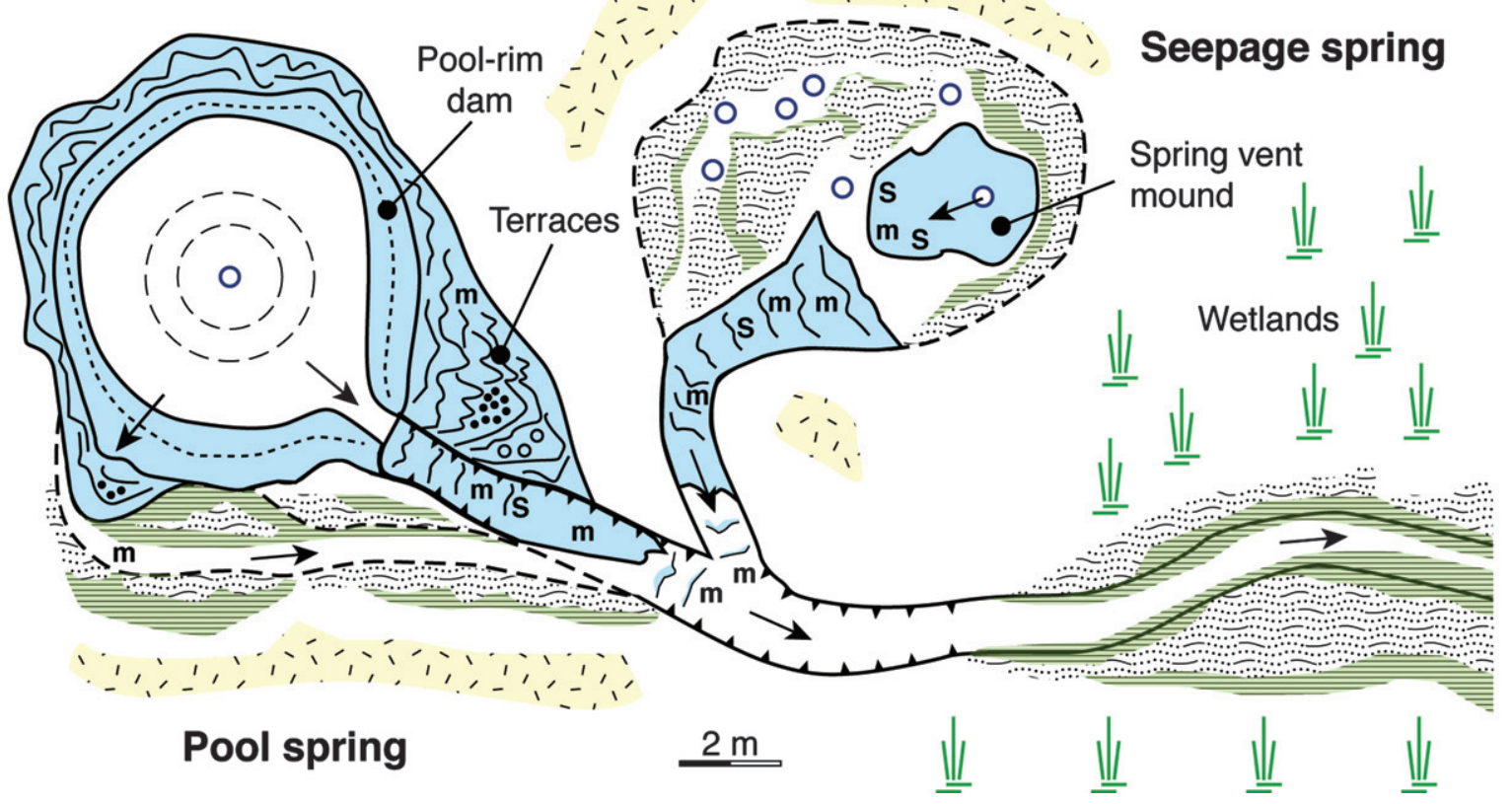

Fig. 17. Summary of the distribution of precipitated minerals at Loburu hot springs. (A) General mineral zonation. Carbonates are proximal, with non-crystalline silica (opal-A) precipitation mainly in cooler distal settings and proximal settings where evaporative concentration allows silica to precipitate at and above the air-water interface. (B) Saturation indices and ranges for selected minerals in the Loburu hot-spring waters, calculated using SOLMINEQ88 (Kharaka et al., 1988; figure modified from Owen et al., 2008). Horizontal bars show the total range of calculated saturation values; dot represents the mean value of 29 water analyses sampled at Loburu hot springs over more than 30 years.

elsewhere, where aqueous silica concentrations exceed those at Loburu, both calcite and opal-A co-precipitate at the vent (Jones et al., 1996). Fluorite, where present, forms in both vadose and phreatic settings where spring fluids have cooled from boiling to below $c a 60^{\circ} \mathrm{C}$ and the level of calcite saturation has decreased (Owen et al., 2008).

\section{Implications for other rift lakes and palaeorifts}

The results of this study show some of the complexity of interpreting spring carbonates in closed rift basins, especially where hot springs discharge along faulted lake margins. Travertine formation in rifts is intermittent, and simplistic 
palaeoclimatic interpretations (for example, that travertine precipitation is linked to wetter conditions) may be incorrect. Every geothermal site has specific local controls on travertine or sinter formation that reflect the regional geology, particularly faulting (Curewitz \& Karson, 1997; Brogi et al., 2010), the hydrogeology (Sturchio et al., 1993) and the geothermal gradient. Neighbouring geothermal sites do not necessarily always respond in the same way to the same environmental changes or tectonic adjustments.

High-temperature travertines precipitated from boiling water such as those at Loburu and Chemurkeu are rare in the East African Rift. The largest travertine deposits in East Africa, at Songwe in Tanzania, discharge at up to $80^{\circ} \mathrm{C}$ from fault-line springs onto an alluvial valley floor rather than a lake margin (Pisarskii et al., 1998; Hochstein et al., 2000; Delvaux et al., 2010). Lake-margin travertines have been reported from several other East African rift basins, including Lake Albert, Uganda (Bahati et al., 2010), and Ethiopia (Chernet, 2011), but none have been studied in detail, so direct comparisons cannot yet be made.

The paucity of travertine partly reflects the predominance of $\mathrm{Na}-\mathrm{HCO}_{3}$ hot-spring waters in East Africa, which are usually calcium poor. Tufas, in contrast, that precipitated from cooler $\left(\mathrm{T}<50^{\circ} \mathrm{C}\right)$ less saline springs, are relatively common and linked to Ca-bearing ground waters with shallower circulation and lower residence time than those that produce high-temperature travertine. Many tufas, including those near Lake Bogoria, formed in fluvial settings rather than along lake margins, so lake-level fluctuations have had less impact on their formation. The warm $\left(\mathrm{T}<50^{\circ} \mathrm{C}\right)$ springs probably respond more quickly to climate variability than those fed primarily by hotter deeply sourced fluids. The lower axial parts of rift basins where the crust is typically thinnest, nonetheless, are the loci for both high-enthalpy fluids and for the major lakes.

The impact of periodic submergence on carbonate precipitation at the Loburu hot springs differs from that for many other travertines that have precipitated in alkaline lakes. Many sublacustrine 'tufas' (spring carbonates in general terms) have formed where dilute Ca-bearing spring fluids have discharged into alkaline lake waters that provided much of the $\mathrm{CO}_{3}{ }^{2-}$ (Benson, 1994; Arp et al., 1999; Pache et al., 2001; Rosen et al., 2004; Coolbaugh et al., 2009). In contrast, the modern high-temperature springs at Lake Bogoria are all Ca-poor $\left(<2 \mathrm{mg} \mathrm{l}^{-1}\right)$ and both the lake and the spring waters are alkaline with high $\mathrm{HCO}_{3}{ }^{-}$and $\mathrm{CO}_{3}{ }^{2-}$ concen- trations. More calcium becomes available in the lake water (and possibly also in spring fluids) during relatively humid periods. $\mathrm{Most}^{\mathrm{CaCO}_{3}}$ then precipitates around the shallow lake margins as calcite stromatolites on firm littoral substrates, rather than being restricted to submerged travertine substrates around spring vents.

Carbonates commonly form in ground water seepage zones around lake margins in rifts (Lazareva et al., 2011; see references in Gierlowski-Kordesch, 2010; Alonso-Zarza \& Wright, 2010), but fossil thermogene examples analogous to those at Loburu appear to be rare. Birney de Wet \& Hubert (1989) described hot-spring deposits that formed on the margins of a Jurassic alkaline rift lake, but those deposits were mainly silica in composition. Melezhik \& Fallick (2001), however, described Palaeoproterozoic hot-spring travertines from Russia that have many similarities. Those travertines formed on the margin of a closed, evaporative rift lake and are hosted by lacustrine sediments, including carbonate stromatolites. The travertine had low relief. Stratigraphic and geochemical evidence confirms several phases of growth, separated by phases of dissolution; they also contain silica crusts that were inferred to have precipitated by capillary evaporation in a semi-arid environment.

\section{CONCLUSIONS}

Detailed sedimentological, mineralogical, petrographic and geochemical studies of the travertines at Loburu, Lake Bogoria, have led to the following conclusions:

1 The shoreline travertines are composed mainly of dendritic and platy calcite that precipitated subaerially from $\mathrm{Na}-\mathrm{Ca}-\mathrm{HCO}_{3}$ waters at temperatures close to boiling point, forming poolrim dams, low terraces and small $(<3 \mathrm{~m}$ high $)$ vent mounds.

2 Calcite and minor aragonite precipitated at the vents either because of, or during, exsolution of $\mathrm{CO}_{2}$ in spring fluids with temperatures of $>80^{\circ} \mathrm{C}$.

3 Most exposed travertines are relict, but minor calcite is precipitating at several modern springs (KL-1, KL-6, KL-8, KL-9 and KL-10) in waters with temperatures of $>90^{\circ} \mathrm{C}$.

4 Stratigraphic evidence confirms that the travertines formed in several phases, separated sometimes by long periods without carbonate precipitation, during which some older traver- 
tines were repeatedly eroded, buried by deltaic sediments and then later exhumed.

5 Radiometric ages, obtained by different methods, imply that the oldest deposits are of late Pleistocene age ( $\mathrm{ca} 30$ to $35 \mathrm{ka}$ ). Most of the travertine might have formed during this late Pleistocene phase, but later periods of carbonate precipitation are confirmed by stratigraphic relations between the travertine and lacustrine stromatolites.

6 Spring carbonate precipitation at Loburu is favoured at 'intermediate' lake levels, when the lake level is neither too high (at or near overflow level: overfilled) nor too low (when trona or nahcolite is precipitating: underfilled). The 'travertine window', when carbonates precipitate at the springs, occurs whenever shallow boiling associated with decreasing hydrostatic pressure favours calcite precipitation by $\mathrm{CO}_{2}$ degassing both at, and just below, the land surface.

7 The distribution of lacustrine carbonate stromatolites in saline, alkaline lakes is controlled by lake hydrochemistry, which depends on lakelevel variations driven mainly by climate. The vertical range of lake levels within which stromatolites form on stable substrates is termed the 'stromatolite window'.

Outstanding problems in interpreting the origin of the Lake Bogoria travertines are the nature, impact and chronology of neotectonic events, and the need for a better understanding of the geothermal system, particularly the fluid origins, their dynamics and the depth(s) of boiling. The ArusBogoria geothermal field is now being studied for its geothermal power potential (Mulwa et al., 2006; Mwawongo, 2006; Karingithi \& Wambugu, 2008, 2010; Simiyu, 2010). The results of those geophysical and geochemical studies will further help to constrain the conditions under which the Loburu and Chemurkeu travertines formed.

\section{ACKNOWLEDGEMENTS}

This research was funded by the Natural Sciences and Engineering Research Council of Canada (RG629-08 to RWR, A6090 to BJ and 249565-02 to KOK), the Hong Kong Baptist University (FRG/ 08-09/II-25 to RBO), the Hong Kong Research Grants Council (201709 to RBO) and Elf Petroleum Norge AS (2231-01 ELF to JJT, RWR and CT). The research is part of a cooperative programme with the National Oil Corporation of Kenya (NOCK). Special thanks are owed to the
NOCK Managing Directors for scientific, administrative and logistical support. Research in Kenya was undertaken under several research permits issued by the Office of the President and the Ministry of Science and Technology, Republic of Kenya, which we gratefully acknowledge. We especially thank William Kimosop, Chief Warden of the North Kenya Rift, his staff and the local community for their continuing support of our work at Lake Bogoria. The late Michael R. Talbot and Johan L. Aksnes kindly provided their unpublished U/Th ages for travertine samples that they sampled at Loburu and Chemurkeu during our field season in 1996. We especially thank Peter Swart and Concha Arenas for their valuable suggestions, and the anonymous journal reviewers for their many helpful comments on the original manuscript.

\section{REFERENCES}

Allen, E.T. (1934) Neglected factors in the development of thermal springs. Proc. Natl. Acad. Sci. USA, 20, 345-349.

Allen, D.J., Darling, W.G. and Burgess, W.G. (1989) Geothermics and hydrogeology of the southern part of the Kenya Rift Valley with emphasis on the Magadi-Nakuru area. Brit. Geol. Surv. Res. Rep., SD/89/1, 68 pp (and appendices).

Alonso-Zarza, A.M. and Wright, V.P. (2010) Palustrine carbonates. In: Carbonates in Continental Settings: Facies, Environments, and Processes (Developments in Sedimentology, v. 61) (Eds A.M. Alonso-Zarza and L.H. Tanner), pp. 103-131. Elsevier, Amsterdam.

Ambraseys, N.N. (1991) Earthquake hazard in the Kenya Rift: the Subukia earthquake 1928. Geophys. J. Int., 105, 253-269.

Arenas, C. and Pardo, G. (1999) Latest Oligocene-Late Miocene lacustrine systems of the north-central part of the Ebro Basin (Spain): sedimentary facies model and palaeogeographic synthesis. Palaeogeogr. Palaeoclimatol. Palaeoecol., 151, 127-148.

Arnórsson, S. (1989) Deposition of calcium carbonate minerals from geothermal waters - theoretical considerations. Geothermics, 18, 33-39.

Arp, G., Thiel, V., Reimer, A., Michaelis, W. and Reitner, J. (1999) Biofilm exopolymers control microbialite formation at thermal springs discharging into alkaline Pyramid Lake, Nevada, USA. Sed. Geol., 126, 159-176.

Bahati, G., Natukunda, J.F. and Tuhumwire, J. (2010) Geothermal energy in Uganda, country update. Proceedings of the World Geothermal Congress, Bali, Indonesia, 25-29 April 2010, 8 pp.

Benson, L.V. (1978) Fluctuation in the level of Lake Lahontan during the last 40,000 years. Quatern. Res., 9, 300-318.

Benson, L.V. (1994) Carbonate deposition, Pyramid Lake Subbasin, Nevada, 1. Sequence of formation and elevational distribution of carbonate deposits (Tufas). Palaeogeogr. Palaeoclimatol. Palaeoecol., 109, 55-87.

Birney de Wet, C.C. and Hubert, J.F. (1989) The Scots Bay Formation, Nova Scotia, Canada, a Jurassic carbonate lake with silica-rich hydrothermal springs. Sedimentology, 36, 857-873. 
Bohacs, K.M., Carroll, A.R., Neal, J.E. and Mankiewicz, P.J. (2000) Lake-basin type, source potential, and hydrocarbon character: an integrated sequence-stratigraphic-geochemical framework. In: Lake Basins Through Space and Time (Eds E.H. Gierlowski-Kordesch and K.R. Kelts), AAPG Stud. Geol., 46, 157-168.

Bonny, S. and Jones, B. (2003) Relict tufa at Miette Hot Springs, Jasper National Park, Alberta, Canada. Can. J. Earth Sci., 40, 1459-1481.

Brock, T.S. (1978) Thermophilic Microorganisms and Life at High Temperatures. Springer, New York, 465 pp.

Brogi, A., Capezzuoli, E., Aqué, R., Branca, M. and Voltaggio, M. (2010) Studying travertines for neotectonics investigations: Middle-Late Pleistocene syn-tectonic travertine deposition at Serre di Rapolano (Northern Apennines, Italy). Int. J. Earth Sci., 99, 1383-1398.

Bryan, T.S. (2005) Geysers: What They are and How They Work, 2nd edn. Mountain Press, Missoula, 70 pp.

Bryan, T.S. (2008) The Geysers of Yellowstone, 4th edn. University Press of Colorado, Boulder, $461 \mathrm{pp}$.

Canet, C., Prol-Ledesma, R.M., Proenza, J.A., Rubio-Ramos, M.A., Forrest, M.J., Torres-Vera, M.A. and Rodríguez-Díaz, A.A. (2005) $\mathrm{Mn}-\mathrm{Ba}-\mathrm{Hg}$ mineralization at shallow submarine hydrothermal vents in Bahía Concepción, Baja California Sur, Mexico. Chem. Geol., 224, 96-112.

Capezzuoli, E. and Gandin, A. (2005) Facies distribution and microfacies of thermal-spring travertine from Tuscany. In: Proceedings of the 1st International Symposium on Travertine (Eds M. Özkul, S. Yağiz and B. Jones), pp. 43-49. Kozan Ofset Maatbaacılık San ve. Tic. Ltd., Şti, Ankara.

Casanova, J. (1986) Les Stromatolites Continentaux: Paléoécologie, Paléohydrologie, Paléoclimatologie. Application au Rift Gregory. Thèse Docteur d'Etat-Sciences, Université d'Aix Marseille II, 256 pp.

Casanova, J. (1987a) Travertins et stromatolites: Les travertines. In: Le demi-graben de Baringo-Bogoria, Rift Gregory, Kenya: 30,000 ans d'histoire hydrologique et sédimentaire (Eds J.J. Tiercelin and A. Vincens), Bull. Centres Rech. Explor.-Prod. Elf-Aquitaine, 11, 481-484.

Casanova, J. (1987b) Travertins et stromatolites: Chronologie. In: Le demi-graben de Baringo-Bogoria, Rift Gregory, Kenya: 30,000 ans d'histoire hydrologique et sédimentaire (Eds J.J. Tiercelin and A. Vincens), Bull. Centres Rech. Explor.-Prod. Elf-Aquitaine, 11, 498-499.

Casanova, J. (1994) Stromatolites from the East African Rift: a synopsis. In: Phanerozoic Stromatolites, II (Eds J. BertrandSafarti and C. Monty), pp. 193-226. Kluwer, Dordrecht.

Casanova, J. and Renaut, R.W. (1987) Les stromatolites du milieu hydrothermal. In: Le demi-graben de Baringo-Bogoria, Rift Gregory, Kenya: 30,000 ans d'histoire hydrologique et sédimentaire (Eds J.J. Tiercelin and A. Vincens), Bull. Centres Rech. Explor.-Prod. Elf-Aquitaine, 11, 484-490.

Chafetz, H.S. and Folk, R.L. (1984) Travertines: depositional morphology and the bacterially constructed constituents. J. Sed. Petrol., 54, 289-316.

Chafetz, H.S. and Guidry, S.A. (1999) Bacterial shrubs, crystal shrubs, and ray-crystal shrubs: bacterial vs. abiotic precipitation. Sed. Geol., 126, 57-74.

Chafetz, H.S. and Guidry, S.A. (2003) Deposition and diagenesis of Mammoth Hot Springs travertine accumulation, Yellowstone National Park, Wyoming, USA. Can. J. Earth Sci., 40, 1515-1529.

Chafetz, H.S. and Lawrence, J.R. (1994) Stable isotopic variability within modern travertines. Géog. Phys. Quatern., 48, 257-273.
Chernet, T. (2011) Geology and hydrothermal resources in the northern Lake Abaya area (Ethiopia). J. Afr. Earth Sci., 61, 129-141.

Cioni, R., Fanelli, G., Guidi, M., Kinyariro, J.K. and Marini, L. (1992) Lake Bogoria hot springs (Kenya): geochemical features and geothermal implications. J. Volcanol. Geotherm. Res., 50, 231-246.

Clarke, M.C.G., Woodhall, D.G., Allen, D. and Darling, G. (1990) Geological, Volcanological and Hydrogeological Controls on the Occurrence of Geothermal Activity in the Area Surrounding Lake Naivasha, Kenya. Ministry of Energy, Republic of Kenya, 138 pp.

Clément, J.-P., Caroff, M., Hémond, C., Tiercelin, J.-J., Bollinger, C., Guillou, H. and Cotton, J. (2003) Pleistocene magmatism in a lithospheric transition area: petrogenesis of alkaline and peralkaline lavas from the Baringo-Bogoria Basin, central Kenya Rift. Can. J. Earth Sci., 40, 12391257.

Cohen, A.S., Talbot, M.R., Awramik, S.M., Dettman, D.L. and Abell, P. (1997) Lake level and paleoenvironmental history of Lake Tanganyika, Africa, as inferred from late Holocene and modern stromatolites. Geol. Soc. Am. Bull., 109, 444460.

Coolbaugh, M., Lechler, P., Sladek, C. and Kratt, C. (2009) Carbonate tufa columns as exploration guides for geothermal systems in the Great Basin. Geotherm. Res. Council Trans., 33, 461-466.

Craig, H. (1957) Isotopic standards for carbon and oxygen and correction factors from mass spectrometric analysis of carbon dioxide. Geochim. Cosmochim. Acta, 12, 133-149.

Crane, K. (1981) Thermal variations in the Gregory Rift of southern Kenya (?). Tectonophysics, 74, 239-262.

Curewitz, D. and Karson, J.A. (1997) Structural settings of hydrothermal outflow: fracture permeability maintained by fault propagation and interaction. J. Volcanol. Geoth. Res., 79, 149-168.

D’Alessandro, W., Giammanco, S., Bellomo, S. and Parello, F. (2007) Geochemistry and mineralogy of travertine deposits on the SW flank of Mt. Etna (Italy): relationships with past volcanic and degassing activity. J. Volcanol. Geoth. Res., 165, 64-70.

Darling, W.G., Griesshaber, E., Andrews, J.N., Armannson, H. and O'Nions, R.K. (1995) The origin of hydrothermal and other gases in the Kenya Rift Valley. Geochim. Cosmochim. Acta, 59, 2501-2512.

Darling, W.G., Gizaw, B. and Arusei, M.K. (1996) Lakegroundwater relationships and fluid-rock interaction in the East African Rift Valley: isotopic evidence. J. Afr. Earth Sci., 22, 423-431.

Delvaux, D., Kraml, M., Sierralta, M., Wittenberg, A., Mayalla, J.W., Kabaka, K., Chamba, M. and GEOTHERM Working Group (2010) Surface exploration of a viable geothermal resource in Mbeya area, SW Tanzania. Part I: Geology of the Ngozi-Songwe geothermal system. Proceedings of the World Geothermal Congress, Bali, Indonesia, 25-29 April 2010, 7 pp.

Dilsiz, C., Marques, J.M. and Carreira, P.M.M. (2004) The impact of hydrological changes on travertine deposits related to thermal springs in the Pamukkale area (SW Turkey). Environ. Geol., 45, 808-817.

Dramis, F., Materazzi, M. and Cilla, G. (1999) Influence of climatic changes on freshwater travertine deposition: a new hypothesis. Phys. Chem. Earth (A), 10, 893-897.

Dunkley, P.N., Smith, M., Allen, D.J. and Darling, W.G. (1993) The geothermal activity and geology of the northern sector 
of the Kenya Rift Valley. Brit. Geol. Surv. Res. Rep., SC/93/1, 185.

Ekmekci, M., Gunay, G. and Simsek, S. (1995) Morphology of the rimstone pools at Pamukkale, Western Turkey. Cave Karst Sci., 22, 103-106.

Eugster, H.P. and Jones, B.F. (1979) Behavior of major solutes during closed-basin brine evolution. Am. J. Sci., 279, 609631.

Fontes, J.-C. and Pouchan, P. (1975) Les cheminées du lac Abhé (TFAI): stations hydroclimatiques de l'Holocène. $C R$ Acad. Sci. Paris, Sér D., 280, 383-386.

Ford, T.D. and Pedley, H.M. (1996) A review of tufa and travertine deposits of the world. Earth-Sci. Rev., 41, 117-175.

Fouke, B.W. (2011) Hot-spring systems geobiology: abiotic and biotic influences on travertine formation at Mammoth Hot Springs, Yellowstone National Park, USA. Sedimentology, 58, 170-219.

Fournier, R.O. (1985) Carbonate transport and deposition in the epithermal environment. In: Geology and Geochemistry of Epithermal Systems (Eds B.R. Berger and P.M. Bethke), Soc. Econ. Geol. Rev. Econ. Geol., 2, 63-72.

Galenko, K. and Zhuravlev, V.A. (Eds) (1994) Physics of Dendrites: Computational Experiments. World Scientific Publishing Co., Singapore, 199 pp.

Geptner, A., Kristmannsdóttir, H., Kristjansson, J. and Marteinsson, V. (2002) Biogenic saponite from an active submarine hot spring, Iceland. Clay Clay Mineral., 50, 174185.

Gierlowski-Kordesch, E.H. (2010) Lacustrine carbonates. In: Carbonates in Continental Settings: Facies, Environments, and Processes (Developments in Sedimentology, v. 61) (Eds A.M. Alonso-Zarza and L.H. Tanner), pp. 1-101. Elsevier, Amsterdam.

Giggenbach, W.F., Sheppard, D.S., Robinson, B.W., Stewart, M.K. and Lyon, G.L. (1994) Geochemical structure and position of the Waiotapu Geothermal Field, New Zealand. Geothermics, 23, 217-262.

Glover, R.B. (1972) Chemical Characteristics of Water and Steam Discharges in the Rift Valley of Kenya. Unpublished Report, Geothermal Resources Exploration Project, United Nations-East Africa Power and Lighting, Nairobi, Kenya, 59 pp (and appendices).

Grant, W.D. and Tindall, B.J. (1986) The alkaline saline environment. In: Microbes in Extreme Environments (Eds R.A. Herbert and G.A. Codd), pp. 25-54. Academic Press, London.

Griffiths, P.S. (1977) Geology of the Lake Hannington-Perkerra River Area, Kenya Rift Valley. PhD thesis, University of London, 187 pp.

Grove, A.T., Street, F.A. and Goudie, A.S. (1975) Former lake levels and climatic change in the Rift Valley of southern Ethiopia. Geogr. J., 141, 177-194.

Guido, D.M. and Campbell, K.A. (2011) Jurassic hot spring deposits of the Deseado Massif (Patagonia, Argentina): characteristics and controls on regional distribution. J. Volcanol. Geoth. Res., 203, 35-47.

Guo, X. and Chafetz, H.S. (2012) Large tufa mounds, Searles Lake, California. Sedimentology. doi: 10.1111/j.1365-3091. 2011.01315.x.

Guo, L. and Riding, R. (1998) Hot-spring travertine facies and sequences, Late Pleistocene, Rapolano Terme, Italy. Sedimentology, 45, 163-180.

Hackman, B.D. (1988) Geology of the Baringo-Laikipia area. Rep. Mines Geol. Dept. Kenya, 104, 79 pp.

Harper, D.M., Childress, R.B., Harper, M.M., Boar, R.R., Hickley, P., Mills, S.C., Otieno, N., Drane, T., Vareschi, E.,
Nasirwa, O., Mwatha, W.E., Darlington, J.P.E.C. and Escuté-Gasulla, X. (2003) Aquatic biodiversity and saline lakes: Lake Bogoria National Reserve, Kenya. Hydrobiologia, 500, 259-276.

Hautot, S., Tarits, P., Whaler, K., Le Gall, B., Tiercelin, J.-J. and Le Turdu, C. (2000) Deep structure of the Baringo Rift Basin (central Kenya) from three-dimensional magnetotelluric imaging: implications for rift evolution. J. Geophys. Res., 105, 23493-23518.

Hindák, F. (2001) Thermal microorganisms from a hot spring on the coast of Lake Bogoria, Kenya. Nova Hedwigia, Beih., 123, 77-93.

Hochstein, M.P. (1999) Geothermal systems along the EastAfrican Rift. Bull. Hydrogéol., 17, 301-310.

Hochstein, M.P., Temu, E.P. and Moshy, C.M.A. (2000) Geothermal resources of Tanzania. Proceedings of the World Geothermal Congress, Kyushu-Tohoku, Japan, 28 May-10 June, 2000, 1233-1238.

Holzbecher, E. (2005) Groundwater flow pattern in the vicinity of a salt lake. Hydrobiologia, 532, 233-242.

Icole, M., Masse, J.-P., Perinet, G. and Taieb, M. (1990) Pleistocene lacustrine stromatolites, composed of calcium carbonate, fluorite, and dolomite, from Lake Natron, Tanzania: depositional and diagenetic processes and their paleoenvironmental significance. Sed. Geol., 69, 139-155.

Johansson, J. and Svensson, J. (2002) Land degradation in the semi-arid catchment of Lake Baringo, Kenya. Projketarab. Göteborgs Univ., B3443, 79.

Johnson, C.R., Ashley, G.M., De Wet, C.B., Dvoretsky, R., Park, L., Hover, V.C., Owen, R.B. and McBrearty, S. (2009) Tufa as a record of perennial fresh water in a semi-arid rift basin, Kapthurin Formation, Kenya. Sedimentology, 56, 1115-1137.

Jones, B.F. and Deocampo, D.M. (2003) Geochemistry of saline lakes. In: Treatise on Geochemistry, Vol. 5 (Ed. J.I. Drever), pp. 393-424. Elsevier, Amsterdam.

Jones, B. and Renaut, R.W. (1995) Noncrystallographic calcite dendrites from hot-spring deposits at Lake Bogoria, Kenya. J. Sed. Res., 64, 154-169.

Jones, B. and Renaut, R.W. (1998) Origin of platy calcite crystals in hot-spring deposits of the Kenya Rift Valley. J. Sed. Res., 69, 913-926.

Jones, B., Renaut, R.W. and Rosen, M.R. (1996) High-temperature $\left(>90^{\circ} \mathrm{C}\right)$ calcite precipitation at Waikite Hot Springs, North Island, New Zealand. J. Geol. Soc. London, 153, 481-496.

Jones, B., Renaut, R.W. and Rosen, M.R. (2003) Silicified microbes in a geyser mound: the enigma of low-temperature cyanobacteria in a high-temperature setting. Palaios, 18, 87109.

Karingithi, C. and Wambugu, J. (2008) Geochemical survey case study of Arus and Bogoria geothermal prospects. Papers, Short Course III on Exploration for Geothermal Resources, United Nations University Geothermal Training Programme, Lake Bogoria-Lake Naivasha, Kenya, 24 October-17 November, 17 pp.

Karingithi, C. and Wambugu, J. (2010) The geochemistry of Arus and Bogoria geothermal prospects. Proceedings of the World Geothermal Congress, Bali, Indonesia, 25-29 April 2010, 6 pp.

Kharaka, Y.K., Gunter, W.D., Aggarwal, P.K., Perkins, E.H. and DeBraal, J.D. (1988) SOLMINEQ.88: a computer program for geochemical modeling of water-rock interactions. US. Geol. Surv. Water Resour. Inv. Rep., 88-4227, 420 pp. 
Krienitz, L., Ballot, A., Kotut, K., Wiegand, C., Pütz, S., Metcalf, J.S., Codd, G.A. and Pflugmacher, S. (2003) Contribution of hot spring cyanobacteria to the mysterious deaths of Lesser Flamingos at Lake Bogoria, Kenya. FEMS Microbiol. Ecol., 43, 141-148.

Krienitz, L., Ballot, A., Casper, P., Kotut, K., Wiegand, C. and Pflugmacher, S. (2005) Cyanobacteria in hot springs of East Africa and their potential toxicity. Algol. Stud., 117, 297306.

Kristmannsdóttir, H., Olafsson, M. and Thorhallsson, S. (1989) Magnesium silicate scaling in district heating systems in Iceland. Geothermics, 18, 191-198.

Lazareva, E.V., Zhmodik, S.M., Melgunov, M.S., Petrova, I.V. and Bryanskaya, A.V. (2011) Redistribution of radionuclides between a microbial mat and a carbonate body at the Garga hot spring (Baikal Rift Zone). Dokl. Earth Sci., 439, 1131-1137.

Le Turdu, C., Tiercelin, J.-J., Richert, J.P., Rolet, J., Xavier, J.P., Renaut, R.W., Lezzar, K. and Coussement, C. (1999) Influence of preexisting oblique discontinuities on the geometry and evolution of extensional fault patterns: evidence from the Kenya Rift using SPOT imagery. In: Geoscience of Rift Systems - Evolution of East Africa (Ed. C.K. Morley), AAPG Stud. Geol., 44, 173-191.

Mahon, W.A.J., McDowell, G.D. and Finlayson, J.B. (1980) Carbon dioxide: its role in geothermal systems. NZ J. Sci., 23, 133-148.

Marker, R.E. (1971) Waterfall tufas: a facet of karst geomorphology in South Africa. Z. Geomorphol. Suppl. Bd., 12, 138-152.

McCall, G.J.H. (1957) Geology and groundwater conditions in the Nakuru area. Tech. Rep. Minist. Works Kenya (Hydraul. Br.), 3, 35 pp.

McCall, G.J.H. (1967) Geology of the Nakuru-Thomson's FallsLake Hannington area. Rep. Geol. Surv. Kenya, 78, 122 pp.

McCall, J. (2010) Lake Bogoria, Kenya: hot and warm springs, geysers and Holocene stromatolites. Earth-Sci. Rev., 103, 71-79.

McLin, K.S., Moore, J.N., Bowman, J.R. and McCullock, J.E. (2012) Mineralogy and fluid inclusion gas chemistry of production well mineral scale deposits at the Dixie Valley geothermal field, USA. Geofluids, 12. doi: 10.1111/j.14688123.2012.00363.x.

Melezhik, V.A. and Fallick, A.E. (2001) Palaeoproterozoic travertines of volcanic affiliation from a ${ }^{13} \mathrm{C}$-rich rift lake environment. Chem. Geol., 173, 293-312.

Minissale, A., Kerrick, D.M., Magro, G., Murrell, M.T., Paladini, M., Rihs, S., Sturchio, N.C., Tassi, F. and Vaselli, O. (2002) Geochemistry of Quaternary travertines in the region north of Rome (Italy): structural, hydrologic and paleoclimatic implications. Earth Planet. Sci. Lett., 203, 709-728.

Mulwa, J., Barongo, P. and Patel, J. (2006) Preliminary magnetotelluric survey results of Arus-Bogoria geothermal prospect, Kenya. IAGA 18th Workshop on Electromagnetic Induction in the Earth, El Vendrell, Spain, 17-23 September 2006, Extended Abstracts, S7-E5, 1-5.

Mwawongo, G.M. (2006) Kenya's geothermal prospects outside Olkaria: status of exploration and development. UN University, Geothermal Training Prog., Reykjavík, Rep., 4, 41-50.

Naylor, I. (1972) The Geology of the Lake Hannington Geothermal Prospect. Unpublished Report, United Nations Development Programme - East Africa Power and Lighting Co. Ltd., Nairobi, 27 pp.
Nelson, S.T., Karlsson, H.R., Paces, J.B., Tingey, D.G., Ward, S. and Peters, M.T. (2001) Paleohydrologic record of spring deposits in and around Pleistocene pluvial Lake Tecopa, southeastern California. Geol. Soc. Am. Bull., 113, 659-670.

Nicholson, K. (1993) Geothermal Fluids: Chemistry and Exploration Techniques. Springer, Berlin, 263 pp.

Olago, D., Opere, A. and Barongo, J. (2009) Holocene palaeohydrology, groundwater and climate change in the lake basins of the Central Kenya Rift. Hydrol. Sci. J., 54, 765-780.

Omenda, P. (2008) Status of geothermal exploration in Kenya and future plans for its development. Papers, Short Course III on Exploration for Geothermal Resources, United Nations University Geothermal Training Programme, Lake BogoriaLake Naivasha, Kenya, 24 October-17 November, 13 pp.

O'Neil, J.R. (1968) Hydrogen and oxygen isotope fractionation between ice and water. J. Phys. Chem., 72, 3683-3684.

O'Neil, J.R. and Clayton, R.N. (1964) Oxygen isotope geothermometry. In: Isotopic and Cosmic Chemistry (Eds H. Craig, S.L. Miller and G.J. Wasserburg), pp. 157-168. North Holland, Amsterdam.

Onyando, J.O., Musila, F. and Awer, M. (2005) The use of GIS and remote sensing techniques to analyse water balance of Lake Bogoria under limited data conditions. J. Civ. Eng. Res. Pract., 2, 53-65.

Owen, R.A., Owen, R.B., Renaut, R.W., Scott, J.J., Jones, B. and Ashley, G.M. (2008) Mineralogy and origin of rhizoliths on the margins of saline, alkaline Lake Bogoria, Kenya Rift Valley. Sed. Geol., 203, 143-163.

Özkul, M., Varol, B. and Alçiçek, M.C. (2002) Depositional environments and petrography of Denizli travertines. Mineral Res. Explor. Bul., 125, 13-29.

Pache, M., Reitner, J. and Arp, G. (2001) Geochemical evidence for the formation of a large Miocene "travertine", mound at a sublacustrine spring in a soda lake (Wallerstein Castle Rock, Nördlinger Ries, Germany). Facies, 45, 211230.

Pagé, P. (1987) Les sources hydrothermales: Données isotopiques. In: Le demi-graben de Baringo-Bogoria, Rift Gregory, Kenya: 30,000 ans d'histoire hydrologique et sédimentaire (Eds J.J. Tiercelin and A. Vincens), Bull. Centres Rech. Explor.-Prod. Elf-Aquitaine, 11, 295-298.

Pedley, H.M. and Rogerson, M. (Eds) (2010) Tufas and speleothems: unravelling the microbial and physical controls. Geol. Soc. London Spec. Pub., 336, 362 pp.

Pentecost, A. (2005) Travertine. Springer, Berlin, 445 pp.

Pentecost, A. and Coletta, P. (2007) The role of photosynthesis and $\mathrm{CO}_{2}$ evasion in travertine formation: a quantitative investigation at an important travertine-depositing hot spring, Le Zitelle, Lazio, Italy. J. Geol. Soc. London, 164, 843-853.

Petryshyn, V.A. and Corsetti, F.A. (2011) Analysis of growth directions of columnar stromatolites from Walker Lake, western Nevada. Geobiology, 9, 425-438.

Pirajno, F. (2009) Hydrothermal Processes and Mineral Systems. Springer, Berlin, 1250 pp.

Pisarskii, B.I., Konev, A.A., Levi, K.G. and Delvaux, D. (1998) Carbon dioxide-bearing alkaline hydrotherms and strontium-bearing travertines in the Songwe River valley (Tanzania). Geol. Geofiz., 39, 941-948.

Renaut, R.W. (1982) Late Quaternary Geology of the Lake Bogoria Fault-Trough, Kenya Rift Valley. Unpublished PhD thesis, University of London, 498 pp.

Renaut, R.W. and Jones, B. (1997) Controls on aragonite and calcite precipitation in hot spring travertines at Chemurkeu, Lake Bogoria, Kenya. Can. J. Earth Sci., 34, 801-818. 
Renaut, R.W. and Tiercelin, J.-J. (1994) Lake Bogoria, Kenya Rift Valley: a sedimentological overview. In: Sedimentology and Geochemistry of Modern and Ancient Saline Lakes (Eds R.W. Renaut and W.M. Last), SEPM Spec. Publ., 50, 101123.

Renaut, R.W., Jones, B. and Tiercelin, J.-J. (1998) Rapid in situ silicification of microbes at Loburu hot springs, Lake Bogoria, Kenya Rift Valley. Sedimentology, 45, 1083-1103.

Renaut, R.W., Owen, R.B. and Ego, J.K. (2008) Recent changes in geyser activity at Loburu, Lake Bogoria, Kenya Rift Valley. GOSA Trans., 10, 4-14.

Rihs, S., Condomines, M. and Poidevin, J.-L. (2000) Long-term behaviour of continental hydrothermal systems: U-series study of hydrothermal carbonates from the French Massif Central (Allier Valley). Geochim. Cosmochim. Acta, 64, 3189-3199.

Rinehart, J.S. (1980) Geysers and Geothermal Energy. Springer, Berlin, 223 pp.

Rosen, M.R., Arehart, G.B. and Lico, M.S. (2004) Exceptionally fast growth rate of $<100$-yr-old tufa, Big Soda Lake, Nevada: implications for using tufa as a paleoclimate proxy. Geology, 32, 409-412.

Savascin, M.Y. and Birsoy, R. (1993) Geochemical setting and hydrochemical evolution of three modern saline lakes in central Anatolia. Bull. Geol. Soc. Gr., 28, 485-497.

Simiyu, S.M. (2010) Status of geothermal exploration in Kenya and future plans for its development. Proceedings of the World Geothermal Congress, Bali, Indonesia, 25-29 April 2010, 11 pp.

Simmons, S.F. and Christenson, B.W. (1994) Origins of calcite in a boiling geothermal system. Am. J. Sci., 294, 361400.

Solari, M.A., Hervé, F., Le Roux, J.P., Airo, A. and Sial, A.N. (2010) Paleoclimatic significance of lacustrine microbialites: a stable isotope case study of two lakes at Torres del Paine, southern Chile. Palaeogeogr. Palaeoclimatol. Palaeoecol., 297, 70-82.

Sorey, M.L., Suemnicht, G.A., Sturchio, N.C. and Nordquist, G.A. (1991) New evidence on the hydrothermal system in Long Valley caldera, California, from wells, fluid sampling, electrical geophysics, and age determinations of hot-spring deposits. J. Volcanol. Geoth. Res., 48, 229-263.

Stoffers, P. and Botz, R. (1994) Hydrothermal carbonate formation in Lake Tanganyika, East-Central-Africa. Chem. Geol., 115, 117-122.

Sturchio, N.C., Dunkley, P.N. and Smith, M. (1993) Climatedriven variations in geothermal activity in the northern Kenya Rift Valley. Nature, 362, 233-234.

Tarits, C., Renaut, R.W., Tiercelin, J.-J., Le Hérissé, A., Cotten, J. and Cabon, J.-Y. (2006) Geochemical evidence of hydrothermal recharge in Lake Baringo, central Kenya Rift Valley. Hydrol. Process., 20, 2027-2055.

Tiercelin, J.J. and Vincens, A. (Eds) (1987) Le demi-graben de Baringo-Bogoria, Rift Gregory, Kenya: 30,000 ans d'histoire hydrologique et sédimentaire. Bull. Centres Rech. Explor. Prod. Elf-Aquitaine, 11, 249-540.

Viles, H.A., Taylor, M.P., Nicoll, K. and Neumann, S. (2007) Facies evidence of hydroclimatic shifts in tufa depositional sequences from the arid Naukluft Mountains, Namibia. Sed. Geol., 195, 39-53.

Vincens, A., Casanova, J. and Tiercelin, J.J. (1986) Palaeolimnology of Lake Bogoria (Kenya) during the 4500 BP high lacustrine phase. In: Sedimentation in the African Rifts (Eds L.E. Frostick, R.W. Renaut, I. Reid and J.-J. Tiercelin), Geol. Soc. London Spec. Publ., 25, 323-330.

Walsh, J. (1969) Geology of the Eldama Ravine-Kabarnet area. Geol. Surv. Kenya Rep., 83, 48 pp.

Young, P.A.V., Maguire, P.K.H., Laffoley, N.d'.A. and Evans, J.R. (1991) Implications of the distribution of seismicity near Lake Bogoria in the Kenya Rift. Geophys. J. Int., 105, 665-674.

Zielke, O. and Strecker, M.R. (2009) Recurrence of large earthquakes in magmatic continental rifts: insights from a paleoseismic study along the Laikipia-Marmanet Fault, Subukia Valley, Kenya Rift. Bull. Seismol. Soc. Am., 99, 6170.

Manuscript received 5 February 2010; revision accepted 20 June 2012 